Leila Toledo Martinho

\begin{abstract}
Sharing Brands: Uma perspectiva semiótica da marca no contexto de consumo colaborativo.
\end{abstract}

Dissertação de Mestrado

Dissertação apresentada como requisito parcial para obtenção do grau de Mestre pelo Programa de Pós-graduação em Administração de Empresas do Departamento de Administração da PUC-Rio.

Orientador: Prof. Luís Alexandre Grubits de Paula Pessôa

Rio de Janeiro

Março de 2019 
Leila Toledo Martinho

\section{Sharing Brands: Uma perspectiva semiótica da marca no contexto de consumo colaborativo.}

Dissertação apresentada como requisito parcial para obtenção do grau de Mestre pelo Programa de Pós-graduação em Administração de Empresas do Departamento de Administração da PUC-Rio. Aprovada pela Comissão Examinadora..

Prof. Luís Alexandre Grubits de Paula Pessôa Orientador Departamento de Administração - PUC-Rio

Profa. Roberta Dias Campos Universidade Federal do Rio de Janeiro - UFRJ

Prof. Marcus Wilcox Hemais Departamento de Administração - PUC-Rio 
Todos os direitos reservados. É proibida a reprodução total ou parcial do trabalho sem autorização da universidade, do autor e do orientador.

\section{Leila Toledo Martinho}

Graduou-se em Administração de Empresas pela Universidade Federal do Amazonas em 1989. É pós-graduada em Marketing pela PUC-Rio e em Varejo pelo IBMEC. Atuou como executiva nas áreas de marketing, trade marketing, comercial, operações e planejamento na Coca-Cola e em O Boticário.

Ficha Catalográfica

Martinho, Leila Toledo

Sharing brands : uma perspectiva semiótica da marca no contexto de consumo colaborativo / Leila Toledo Martinho ; orientador: Luís Alexandre Grubits de Paula Pessôa. - 2019.

100 f. : il. color. ; $30 \mathrm{~cm}$

Dissertação (mestrado)-Pontifícia Universidade Católica do Rio de Janeiro, Departamento de Administração, 2019.

Inclui bibliografia

1. Administração - Teses. 2. Consumo colaborativo. 3. Branding. 4. Semiótica. 5. Uber. I. Pessôa, Luís Alexandre Grubits de Paula. II. Pontifícia Universidade Católica do Rio de Janeiro. Departamento de Administração. III. Título 


\section{Agradecimentos}

Ao meu orientador, professor Luís Alexandre Grubits de Paula Pessôa, por seu acolhimento, ensinamentos e por me apresentar a uma nova forma de pensar o marketing e as marcas.

À professora Roberta Campos e ao professor Marcus Hemais por, gentilmente, terem aceitado o convite para compor a banca examinadora e contribuir com a pesquisa.

Aos professores do Mestrado Acadêmico do IAG, pelas propostas apresentadas, sempre ricas e desafiadoras.

Ao meu pai, Miguel, que acompanhou o novo caminho, mas nos deixou antes que o sonho fosse realizado. À minha mãe, Maria, minha primeira professora e eterna mestra, com quem aprendi o verdadeiro significado dessas palavras e a importância que a educação teria em minha vida.

Ao meu marido, Claudio, grande incentivador desta jornada, por seu amor, paciência, apoio e por me fazer acreditar que daria certo.

À minha irmã Luciana, a mestre exemplar, por quem nutro a mais profunda admiração e à minha sobrinha Lucíola, por quem busco me tornar melhor a cada dia.

Às minhas colegas de mestrado, Claudia, Juliana, Marcia, Paloma, Paula e Sylvia, pelo conhecimento compartilhado e pelos momentos que passamos juntas. A trilha foi mais leve porque vocês estavam lá.

Aos entrevistados, por oportunizarem as descobertas feitas nesta pesquisa.

Aos amigos e familiares, pelo incentivo para seguir em frente.

À equipe do IAG, professores e funcionários, pelo apoio.

À PUC-Rio, pela indicação e viabilização da bolsa de estudos.

O presente trabalho foi realizado com apoio da Coordenação de Aperfeiçoamento de Pessoal de Nível Superior -Brasil (CAPES) - Código de Financiamento 001 


\section{Resumo}

Martinho, Leila Toledo; Pessôa, Luís Alexandre Grubits de Paula. Sharing Brands: Uma perspectiva semiótica da marca no contexto de consumo colaborativo. Rio de Janeiro, 2019. 100p. Dissertação de Mestrado Departamento de Administração, Pontifícia Universidade Católica do Rio de Janeiro.

Os últimos dez anos foram marcados pelo nascimento de marcas que rapidamente se converteram em sinônimos de categorias, como Uber e Airbnb. Consideradas protagonistas do consumo colaborativo, tais marcas alcançaram valor de mercado superior ao de marcas tradicionais, transformando segmentos como os de transporte e hotelaria. Estima-se que, nos próximos cinco anos, a economia compartilhada gerará mais de US\$300 bilhões em novos negócios. Neste contexto, esta dissertação tem por objetivo explorar o significado do consumo colaborativo para o consumidor brasileiro, investigando, em especial, de que forma os consumidores interpretam as manifestações da marca Uber, utilizando a perspectiva teórico-metodológica da semiótica discursiva de linha francesa e o modelo Projeto/Manifestação de identidade de marca proposto por Semprini (2010). Os dados foram coletados por meio de quinze entrevistas individuais com consumidores e pesquisa documental. Foram utilizados como unidades de análise o discurso de consumidores acerca do consumo colaborativo e das manifestações da marca Uber, o conteúdo do site oficial da empresa e peças de campanha publicitária veiculada em 2018. Os resultados da pesquisa indicam que o conceito de consumo colaborativo diverge entre os consumidores entrevistados, ratificando a literatura sobre o tema. Através da identificação das aproximações e afastamentos entre o projeto da marca Uber e sua identidade manifesta, os achados apontam que há similaridades entre o projeto enunciado e o que é compreendido pelo público. Há também pontos dissonantes, indicando oportunidades para que os gestores da marca aperfeiçoem as manifestações em prol de uma comunicação de marca mais consistente.

\section{Palavras-chave}

Consumo colaborativo; branding; semiótica; Uber 


\section{Abstract}

Martinho, Leila Toledo; Pessôa, Luís Alexandre Grubits de Paula. Sharing

Brands: A semiotic perspective of the brand in the context of collaborative consumption. Rio de Janeiro, 2019. 100p. Dissertação de Mestrado, Pontifícia Universidade Católica do Rio de Janeiro.

The last ten years have been marked by the emergence brands that quickly converted into categories such as Uber and Airbnb. Considered the protagonists of collaborative consumption, these brands reached higher market value than traditional brands, changing specifics segments like transportation and hospitality. It is estimated that, over the next five years, sharing economy will generate more than $\$ 300$ billion in new businesses. In this context, this research aims to explore the meaning of collaborative consumption for the Brazilian consumers, and investigate, particularly, how consumers interpret Uber brand manifestations, using the theoretical-methodological perspective of the French approach to discursivesemiotics and the Project/Manifestation model of brand identity proposed by Semprini (2010). The data were collected through 15 individual consumers' interviews and documentary research, as well. Consumer's understanding about collaborative consumption and Uber brand's manifestations, in addition to the content of the company's official website and pieces of advertising campaign published in $\mathbf{2 0 1 8}$ were used as units of analysis. The research results indicate that the concept of collaborative consumption is divergent among the consumers interviewed, ratifying the literature. Through the identification of the approaches and departures between the project proposed by Uber brand and its manifest identity, the findings indicate that there are similarities between the brand enunciation and what is understood by the public. However, there are also dissonant points, indicating opportunities for brand managers to optimize the manifestations for a more consistent brand communication.

\section{Keywords}

Collaborative consumption; branding; semiotics; Uber 


\section{Sumário}

1 Introdução 11

1.1. Formulação do Problema 11

1.2. Objetivo 15

1.3. Relevância do estudo 15

1.4. Delimitação do estudo 16

$\begin{array}{ll}\text { 1.5. Organização do estudo } & 17\end{array}$

2 Revisão de literatura $\quad 18$

$\begin{array}{lr}\text { 2.1. Consumo colaborativo } & 18\end{array}$

2.2. A marca na perspectiva da semiótica francesa 27

2.2.1. Semiótica discursiva de linha francesa 27

2.2.2. A característica semiótica das marcas 28

3 Método 34

3.1. Perspectiva qualitativo-interpretativa 34

3.2. Passos Metodológicos $\quad 35$

3.3. Composição do corpus de pesquisa 37

3.3.1. Realização das entrevistas 37

3.4. Limitações do método 41

4 Análise e interpretação dos dados $\quad 42$

4.1. Consumo colaborativo 42

4.1.1. Conceito de consumo colaborativo 43

4.1.2. Práticas de consumo colaborativo 44

4.1.3. Disposição para o consumo colaborativo 47

4.2. A Uber 49

4.2.1. Uber no contexto do consumo colaborativo 52

4.2.2. Motivos para se engajar na plataforma Uber 53

4.2.3. Sentimentos em relação às experiências na Uber 55

4.2.4. O projeto da marca Uber $\quad 57$

4.2.4.1. Informações do site da empresa

4.2.4.2. Filme publicitário campanha "Confiança começa com o nome" 58

4.2.4.3. Recomposição do projeto de marca 63 
4.2.5. As manifestações da marca Uber na perspectiva do consumidor 68

4.2.5.1. Manifestação serviço Uber X 69

4.2.5.2. Manifestação Aplicativo $\quad 75$

4.2.5.3. Manifestação Campanha Publicitária "Confiança começa com o nome" $\quad 77$

4.2.5.4. Identidade manifesta da marca Uber 79

4.2.6. Aproximações e afastamentos entre o projeto de marca Uber e a identidade manifesta $\quad 82$

4.2.7. Relação entre o projeto de marca Uber, a identidade manifesta e os conceitos de consumo colaborativo 83

5 Considerações finais $\quad 88$

6 Referências Bibliográficas 90

7 Anexos $\quad 94$

7.1. Formulário para preenchimento eletrônico 94

7.2. Roteiro de entrevista 96

$\begin{array}{ll}\text { 7.3 Termo de Livre Consentimento } & 97\end{array}$

7.4. Imagens apresentadas durante as entrevistas 98 


\section{Lista de figuras}

Figura 1: llustração do objetivo $\quad 15$

Figura 2: Axiologia do consumo $\quad 31$

Figura 3: A identidade de marca 32

Figura 4: A organização semionarrativa do significado 32

Figura 5: Identidade manifesta como somatório das manifestações da marca 36

Figura 6: Identificação do tipo de aplicativo utilizado 38

Figura 7: Identificação de utilização de aplicativos na última semana 38

Figura 8: Cenas 1 a 4 do filme publicitário

"Confiança começa com o nome" 59

Figura 9: Cena 5 do filme publicitário "Confiança começa com o nome" 59

Figura 10: Cena 6 do filme publicitário "Confiança começa com o nome" 60

Figura 11: Cenas 7 a 9 do filme publicitário "Confiança começa com o nome" 60

Figura 12: Cenas 10 a 12 do filme publicitário "Confiança começa com o nome" 60

Figura 13: Cenas 13 a 18 do filme publicitário "Confiança começa com o nome"

Figura 14: Cenas 19 a 23 do filme publicitário "Confiança começa com o nome" 61

Figura 15: Tipos de valorização encontrados no projeto da marca Uber $\quad 68$

Figura 16: Identidade manifesta da marca Uber, obtida após análise das manifestações 81

Figura 17: Tipos de valorização encontrados nas manifestações da marca Uber

Figura 18: Valores encontrados no projeto da marca e na identidade manifesta da marca Uber

Figura 19: Conceitos encontrados na literatura sobre consumo colaborativo presentes no projeto e na identidade manifesta da marca Uber 


\section{Lista de tabelas}

Tabela 1: Motivos para engajamento em serviços do consumo colaborativo 23

Tabela 2: Resumo das definições e discussões encontradas na literatura $\quad 26$

Tabela 3: Perfil dos entrevistados 39

Tabela 4: Tipos de Serviço oferecidos no Brasil pela Uber 51

Tabela 5: Motivos para engajamento na plataforma Uber 55

Tabela 6: Organização semionarrativa do significado do filme da campanha publicitária "Confiança começa com o nome" 62

Tabela 7: Análise das manifestações da marca Uber 80 


\section{Introdução}

O presente trabalho visa entender de que forma os consumidores interpretam as manifestações da marca Uber, dentro do contexto de consumo colaborativo, avaliando o quanto essas interpretações correspondem ao projeto de marca proposto, bem como investigar os significados de consumo colaborativo na perspectiva do consumidor brasileiro, utilizando uma perspectiva qualitativointerpretativa, em que as unidades de análise são os discursos da marca e de consumidores, à luz da semiótica discursiva de linha francesa, aplicando o modelo Projeto/Manifestações de marca proposto por Semprini (2010).

\section{1.}

\section{Formulação do Problema}

Num curto período de tempo, mais precisamente dez anos, marcas como Uber e Airbnb se transformaram em sinônimos de categorias, produtos ou serviços, conquistando espaço no cotidiano dos consumidores. Facilitadas pela evolução tecnológica, surgiram já com alta capacidade de captar investimentos, revolucionando setores tradicionais e consolidados, como o do transporte de passageiros e o de hotelaria.

Tais marcas são apontadas como protagonistas do fenômeno denominado consumo colaborativo (SUNDARARAJAN, 2016), que promete estabelecer uma nova forma de consumo, mais inclusiva, viável, consciente e responsável, onde a posse cede espaço ao acesso. O fenômeno, considerado um novo modelo de transações econômicas e de acesso ao consumo, apresenta forte apelo entre as gerações mais jovens, e possui várias denominações, dentre elas, economia compartilhada, economia colaborativa, economia circular.

Neste estudo, será utilizado o termo consumo colaborativo, conforme apresentado por Belk (2014, p. 1597):

Pessoas coordenando a aquisição e distribuição de um recurso por um valor ou outra compensação, abrangendo permuta, negociação e troca, envolvendo a concessão e recebimento de compensações não monetárias. Exclui atividades que não possuem compensação envolvida (BELK, 2014, p. 1597). 
Em 2011, a Revista Time Magazine declarou que o consumo colaborativo seria uma das "10 ideias que iriam mudar o mundo". Em 2015, a consultoria Pricewaterhouse Cooper declarou que a economia compartilhada ao redor do mundo havia movimentado US\$ 15 bilhões em receitas no ano anterior. Fundos de investimento como o Colaborative Fund, fundado em 2011, sediado em Nova lorque, investem exclusivamente em empresas que praticam a economia compartilhada. Em sua página na internet, a empresa se apresenta como um fundo que busca atender o interesse individual ("better for me") e o interesse mais amplo ("better for the world") e afirma já ter investido US\$125 milhões em mais de cinquenta projetos. Organizações não lucrativas e com capacidade de captar recursos também dão suporte a essas iniciativas. Uma dessas organizações é a Ouishare, fundada em Paris em 2011. Com um discurso que propõe a prática da "nova economia" e critica o modelo econômico atual, a organização sem fins lucrativos, estimula e dá suporte a projetos de empresas que se enquadrem nas características desse modelo econômico.

A evolução da tecnologia, especialmente da internet e dos dispositivos móveis proporcionaram a popularização dos aplicativos e comunidades voltadas para o consumo colaborativo na rede (WALSH, 2011; PwC, 2015). Facilitadas pelos avanços tecnológicos, empresas e marcas emergiram e têm crescido de forma exponencial. Termos como blockchain, bitcoin, crowdfunding (SUNDARARAJAN, 2016), coworking (BRANDÃO, 2017), cohousing (CÓCOLO, 2018), co-living (KUSISTO, 2018), entre outros, compõem um glossário em formação. Os verbos colaborar e compartilhar estão presentes nos discursos dos indivíduos e das organizações, despertando a atenção da mídia e de investidores. Veículos de comunicação como jornais e emissoras de televisão têm dado destaque ao tema, apresentando modalidades de compartilhamento que estão ganhando espaço no Brasil, desde moradias compartilhadas, denominadas cohousing, a serviços de compartilhamento de carros, bicicletas e plataformas virtuais de empréstimos de objetos entre vizinhos como a "Tem Açúcar? ", criada em 2014. Segundo dados de pesquisa realizada em 2017, pelo SPC e pela Confederação Nacional de Dirigentes Lojistas com consumidores de todas as capitais, divulgados num artigo da Agência Brasil EBC, setenta por cento dos consumidores pesquisados afirmaram que a economia compartilhada "torna a vida mais fácil". Dentre as modalidades utilizadas, a preferência é pela hospedagem em casa de terceiros e pelas caronas compartilhadas. Aproximadamente quarenta por cento dos consumidores afirma já haver trocado a hospedagem em hotéis e o uso do carro, táxi ou transporte público, por hospedagem em casa de terceiros ou 
uso de aplicativos de transportes. Outro dado que pode indicar o crescimento do fenômeno no Brasil, é a queda na emissão de carteiras de habilitação. Segundo levantamento realizado pelo instituto Ipsos, com dados do Detran, observou-se uma redução de cerca de vinte e três por cento no número de carteiras emitidas no período compreendido entre 2014 e 2017. Atribuem-se como causas possíveis, os custos envolvidos para emitir o documento e os associados à aquisição e posse do carro e ainda, a popularização dos aplicativos de transportes, como o da Uber, que passaram a integrar o portfólio de modais de transportes nas grandes cidades brasileiras.

Matéria publicada no jornal O Estado de São Paulo em 2017, informava que o Brasil reúne 32\% das iniciativas de colaboração da América Latina, segundo um estudo elaborado pela escola de negócios IE Business School, o Banco Interamericano de Desenvolvimento (BID) e o Ministério da Economia e Competitividade da Espanha, sugerindo uma posição de protagonismo para o país nesse segmento. O site Consumo Colaborativo Brasil, dedicado a tratar de assuntos relacionados ao tema, reúne cerca de duzentas iniciativas agrupadas em vinte categorias, entre elas, alimentação, carros, animais, banco de tempo, roupas, livros, financiamentos coletivos. Tais iniciativas, sendo a maioria composta por empresas com fins lucrativos, combinam conceitos de compartilhamento, empréstimo, permuta, troca e doação. A marca Uber está classificada no site, na categoria Transportes. A descrição do serviço é feita da seguinte forma: "Uber oferece um serviço semelhante ao taxi, conecta você a um motorista em poucos minutos". Observa-se, no entanto, que essa descrição não está alinhada à forma como a Uber se apresenta em sua página oficial na internet: "Criamos oportunidades ao colocar o mundo em movimento" e ainda "A Uber não é uma empresa de transporte. A Uber é uma empresa de Tecnologia. " e "A Uber não é um aplicativo de táxi."

Em 2009, quando foi fundada, nos Estados Unidos, pretendia oferecer um serviço que conectaria motoristas particulares de carros de luxo a passageiros, através de um aplicativo para dispositivos móveis. Pressionada por concorrentes que ofereciam ridesharing, ou viagens compartilhadas, com preços baixos, e também pela necessidade de escalar o seu modelo, integrou-se à modalidade, lançando o Uber $\mathrm{X}$, serviço no qual, qualquer pessoa poderia aderir e oferecer viagens em seus carros particulares, o que exortou o crescimento da empresa. Em 2015, a Uber captou US\$ 7 bilhões em investimentos, cifra superior à que todas as companhias de consumo colaborativo, juntas, haviam captado até então. Em abril de 2017, esse número alcançou US\$ 11 bilhões estando, entre seus 
investidores, Google Ventures, Goldman Sachs, Morgan Stanley e o CEO da Amazon, Jeff Bezos (SLEE, 2017) e, no final de 2018, foi publicado no The Wall Street Journal, que a empresa estaria avaliada em US\$120 bilhões de dólares.

A redução do ato de consumir não parece ser o alvo primordial do consumo colaborativo. O modelo propõe novas formas de fazê-lo, limitando o desperdício e aumentando a eficiência dos recursos. A partir de 1990, impulsionado pela globalização que promoveu o aumento da oferta de produtos e serviços, maior acesso ao crédito e à expansão tecnológica, o consumo alcançou picos máximos. Nesse contexto, a busca pela diferenciação tornou-se imperativa para os produtos e serviços, trazendo para as marcas, um papel de maior destaque, abrindo espaço para novas marcas que traduzam novas formas de consumo, propondo uma ressignificação para o fenômeno.

Trata-se de ressemantizar o universo do consumo em sua globalidade, de tornar a dar um sentido e um valor ao próprio ato de consumir, de saber mostrar as pessoas que consumir pode ser outra coisa que a simples aquisição de produtos que se necessita (SEMPRINI, 2010, p. 48).

Segundo Semprini (2010), as sociedades contemporâneas estariam em busca de sentido, construindo projetos de vida que as ajudem a dar uma orientação e um significado à sua experiência cotidiana, dentro de um contexto social mais complexo e segmentado, exigindo das marcas, o exercício de um "poder semiótico", ou seja, que criem um projeto de sentido.

Esse poder semiótico refere-se à capacidade da marca em "selecionar os elementos no interior do fluxo de significados que atravessam o espaço social, organizá-los em uma narração pertinente e atraente e a propô-los a seu público" (Semprini, 2010, p. 98).

"Em apenas vinte anos as marcas passaram por uma evolução e transformação profundas, tanto em suas lógicas de funcionamento, como em seu papel e significado", reitera Semprini (2010, p. 25). Dessa forma, o presente estudo se propõe a explorar o significado de consumo colaborativo para os consumidores brasileiros, e a investigar uma marca, neste contexto do consumo, explicitando as aproximações e afastamentos entre o projeto de marca proposto pela Uber e as interpretações das manifestações dessa marca pelos consumidores. 


\section{2.}

\section{Objetivo}

O objetivo deste estudo é entender o significado de consumo colaborativo para o consumidor brasileiro e de que forma os consumidores interpretam as manifestações da marca Uber nesse contexto, através da pergunta de pesquisa:

$\checkmark$ Quais os significados do consumo colaborativo para os consumidores brasileiros e, neste contexto de consumo, quais as aproximações e afastamentos entre $o$ projeto proposto pela marca Uber $\mathrm{e}$ as interpretações das manifestações dessa marca pelos consumidores?

A partir dessa questão, foram criados dois objetivos intermediários:

$\checkmark$ Descrever o projeto proposto pela marca Uber;

$\checkmark$ Entender como os consumidores interpretam as principais manifestações da marca Uber.

A Figura 1 ilustra o objetivo do estudo:

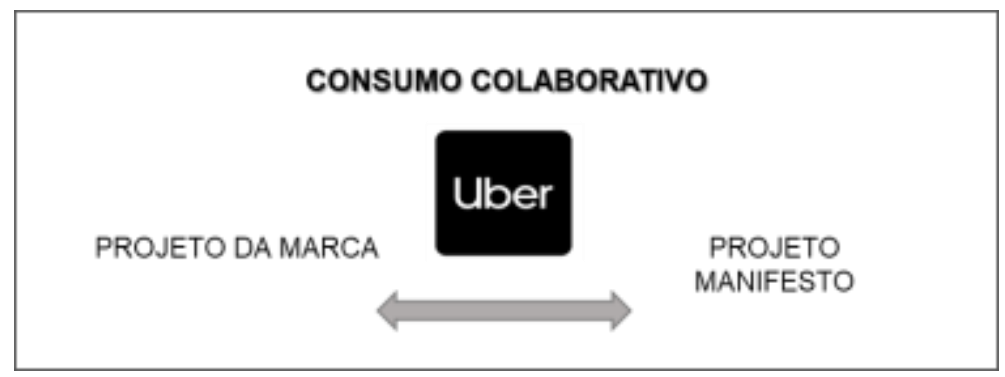

Figura 1: Ilustração do objetivo Fonte: Elaboração própria

\section{3.}

\section{Relevância do estudo}

O volume de publicações acadêmicas sobre $o$ tema consumo colaborativo ainda é relativamente pequeno, mas tem crescido nos últimos anos, especialmente nos Estados Unidos e Europa. Segundo estudo recente, até 2013, observa-se predominância de publicações focadas na perspectiva tecnológica, o que pode ser atribuído ao papel da tecnologia da informação para o desenvolvimento das plataformas desenvolvidas para facilitar a modalidade (ARCIDIACONO; GANDINI, 2018).

Entre 2013 e 2015, observou-se um crescimento de publicações dedicadas a investigar e ilustrar aspectos relativos à governança, motivados aí por uma necessidade de regulamentação das novas empresas, já que a nova modalidade prevê, entre outros elementos, novas formas de trabalho. A partir de 2015, o 
volume de publicações na área das Ciências Sociais começa a crescer, surgindo análises no nível micro (ARCIDIACONO; GANDINI, 2018).

Comparados às publicações que dão destaque à temáticas que relacionam oportunidades e desafios, inovação social e transformação no mercado de trabalho, artigos com temática relacionada ao novo modelo de produção distribuição e consumo ainda são minoria e estão concentrados na análise das realidades da Europa e Estados Unidos (ARCIDIACONO; GANDINI, 2018).

Foram encontrados estudos sobre a marca Uber focados em seu modelo de negócio, suas estratégias de marketing e comportamento de consumo de usuários. Entretanto, não foram encontrados estudos específicos sobre seu projeto de marca e manifestações, bem como de outras marcas de consumo colaborativo. Uma busca pelo termo consumo colaborativo na base de dados da biblioteca da PUC Rio, resultou em trinta e sete artigos publicados em português, no período compreendido entre 2008 e 2018, evidenciando uma lacuna.

Além da natureza inovadora no que tange à escolha da marca e do tipo de consumo que ela representa, conforme apontado na literatura, a escolha da semiótica como método para análise reforça o caráter inovador do estudo. Pessôa (2017) defende a utilização da semiótica no contexto atual, uma vez que:

\begin{abstract}
As marcas assim com os consumidores, têm suas identidades postas a prova a cada interação, em processo contínuo de (re) construção de um posicionamento mercadológico que alinhe decisões administrativas e propicie os resultados esperados por seus gestores, desafiando acadêmicos e praticantes de Marketing e Branding a buscar posturas epistemológicas e metodológicas que respondam a esse cenário (PESSÔA, 2017, p. 1).
\end{abstract}

\title{
1.4.
}

\section{Delimitação do estudo}

O termo consumo colaborativo vem sendo utilizado nos ambientes acadêmico e empresarial, sem que haja consenso sobre seu significado. $O$ presente estudo limita-se a identificar qual o entendimento dos consumidores acerca do termo, comparando-o às perspectivas teóricas que serão analisadas.

Para responder a pergunta de pesquisa e o segundo objetivo intermediário, o estudo tem como foco usuários de aplicativos tecnológicos dedicados ao consumo colaborativo, de acordo com a literatura pesquisada como Uber (BOTSMAN; ROGERS, 2010; BENOIT et al., 2017; LINDBLOM; LINDBLOM, 2017; MITTENDORF, 2017; SUNDARARAJAN, 2016) Airbnb (BARNES; MATTSON, 2017; LINDBLOM; LINDBLOM, 2017; MÖHLMANN, 2015), CouchSurfing (BOTSMAN; ROGERS, 2010), BlaBlaCar (PISCICELLI; COOPER 
e FISCHER, 2015), e que tenham utilizado o serviço recentemente. Seus discursos são utilizados como objetos de análise. Não foram investigadas outras modalidades de consumo, associadas por alguns autores ao consumo colaborativo, como empréstimos e doações, nem tampouco o ato de presentear (gift giving). Para efeito de operacionalização da análise das manifestações da marca Uber pelos entrevistados, foram escolhidas três manifestações: o serviço Uber X, o aplicativo para dispositivos móveis e a campanha "Confiança começa com o nome". Para o desenvolvimento do primeiro objetivo intermediário, que diz respeito especificamente à marca Uber, foram utilizados os dados do site oficial da empresa, e peças publicitárias que fazem parte da campanha "Confiança começa com o nome", veiculada em 2018. Não foram abordados neste estudo os motoristas-parceiros da Uber.

\section{5 .}

\section{Organização do estudo}

A partir desta introdução, o estudo está organizado em mais quatro capítulos, sendo o próximo dedicado a apresentar a revisão de literatura.

Por se tratar de um fenômeno de consumo, o estudo está contextualizado dentro de estudos de consumo, mais especificamente a pesquisas dedicadas ao compartilhamento (sharing) e consumo colaborativo (collaborative consumption), vinculando-se ainda à perspectiva teórica da semiótica discursiva de linha francesa, fundada por Algirdas Julien Greimas, também conhecida como semiótica greimasiana. A sequência na revisão de literatura se dá então com os conceitos de marca na perspectiva da semiótica discursiva de linha francesa (GREIMAS; COURTÉS, 2008), fundamentação teórica que será utilizada para analisar o discurso dos consumidores acerca das manifestações da marca Uber e, por fim, explora o modelo conceitual de Semprini (2010), que aplicou a semiótica aos estudos sobre marca.

O capítulo seguinte expõe o método escolhido e os passos metodológicos da investigação, como se deu a formação do corpus de pesquisa, a realização das entrevistas e as limitações do método. O quarto capítulo descreve os resultados da pesquisa, a análise e a interpretação dos dados, apresentando as evidências empíricas e como se relacionam com a literatura estudada e, no último capítulo, são expressas as considerações finais, implicações gerenciais, bem como as sugestões para pesquisas futuras, concluindo o trabalho. 


\section{2 \\ Revisão de literatura}

Este capítulo discute os aspectos teóricos relacionados ao tema de investigação e está organizado em dois tópicos sendo o primeiro dedicado a apresentar as definições e discussões encontradas na literatura para consumo colaborativo. Foram selecionados na revisão de literatura artigos com foco no comportamento do consumidor, priorizando os estudos realizados sob a perspectiva teórico-metodológica interpretativista. No entanto, julgou-se adequado incluir um artigo com abordagem positivista, por considerar aspectos relevantes para o tema de pesquisa. O segundo tópico se propõe a abordar a marca na perspectiva da semiótica francesa, destacando o modelo Projeto/Manifestação de marca proposto por Semprini (2010), que considera a marca como o "ponto culminante do encontro de três dinâmicas diferentes, a da produção, a da recepção e a dos elementos contextuais" (SEMPRINI, 2010, p. 143).

\section{1.}

\section{Consumo colaborativo}

$\mathrm{Na}$ literatura pesquisada, não há um consenso sobre as definições de consumo colaborativo. Em razão disso, esse tópico busca apresentar como cada autor utiliza o termo, bem como identificar outras terminologias utilizadas pelos autores analisados.

No final da década de 1970, Felson e Spaeth (1978, p. 614) definiram consumo colaborativo como sendo "eventos onde uma ou mais pessoas consumiam bens e serviços, engajadas em atividades conjuntas com uma ou mais pessoas", incluindo aí atos como tomar cerveja com amigos ou compartilhar um passeio de carro.

Mais recentes, os artigos de Belk $(2007,2010,2014)$ são reconhecidos como precursores em estudos dos temas compartilhamento e consumo colaborativo na literatura de comportamento do consumidor. Belk (2007, p. 127) define o compartilhamento como "o ato e o processo de distribuir o que é nosso para outros para seu uso e/ou o ato e o processo de receber ou tomar algo de 
outros para nosso próprio uso", e defende que se trata de uma alternativa à propriedade privada, já que no compartilhamento duas ou mais pessoas podem aproveitar benefícios e também os custos advindos da posse de algo.

Belk (2007) reconhece que o compartilhamento forma comunidades, promove a economia de recursos e cria sinergias, definindo o que é "nosso", mais do que o que é "meu" ou "seu". Podem ser compartilhados não apenas os bens, mas também animais, ideias, valores, tempo.

Para ilustrar o consumo compartilhado, Belk (2007) faz uso de dois protótipos: o da mãe, que compartilha seu corpo com o feto durante a gestação e posteriormente, o seu leite, na infância; e o da família, onde rendimento familiar e demais recursos, são compartilhados entre todos os membros. Em outro artigo sobre o tema, o autor destaca características para o compartilhamento dentro da família, entre elas: a propriedade conjunta, a posse conjunta, não mediação pelo mercado, não existência de compensação financeira e, finalmente, não reciprocidade (BELK, 2010).

O compartilhamento familiar foi escolhido como pano de fundo para o estudo de Levy (2015) com famílias urbanas de classe média baixa brasileira. Em sua pesquisa, a autora encontrou algumas das características identificadas no protótipo de compartilhamento familiar proposto por Belk (2010), como a posse compartilhada e o uso de alguns bens. Mas os resultados do estudo sugeriram que duas características poderiam ser discutidas: a não reciprocidade, já que alguns dos entrevistados demonstraram esperar receber algo em troca ao compartilhar; e não envolver compensação financeira. Para a autora, a condição financeira das famílias objeto do estudo pode estar associada à expectativa de compensação financeira (LEVY, 2015).

A autora observou ainda que, o compartilhamento é "uma prática aprendida socialmente, ensinada aos filhos como necessidade ou como um valor" (LEVY, 2015, p. 277), possibilitando maior acesso aos bens e ainda que quanto mais estreitos os laços relacionais, mais presente se faz o compartilhamento entre os membros da família (LEVY, 2015), ratificando o que Belk (2014) havia postulado.

O compartilhamento está presente nos atos de consumo sob diversas formas. Rituais de compartilhamento foram e continuam sendo observados tanto nas culturas orientais como nas culturas ocidentais. Belk (2010) considera o tema negligenciado na literatura de comportamento do consumidor e examina a natureza do compartilhamento e como ele se diferencia da troca de bens, mediada pelo mercado e do ato de presentear (gift giving). A principal diferença consiste na propriedade que, tanto na troca de bens, como no ato de presentear, é privada. 
Outra diferença se dá em relação à reciprocidade, que se faz presente tanto na troca de bens como no ato de presentear. Embora quem presenteie não espere receber nada em troca, é comum haver uma compensação ao presenteador, por parte do presenteado. Na troca de bens a reciprocidade se dá através da percepção de valor que é atribuída ao bem. Se a pessoa que o comprou, entende que o bem vale o que custou, a recíproca é positiva, caso contrário, é negativa. $A$ distinção consiste no vínculo que existe entre os envolvidos. Na troca de bens, mediada pelo mercado e onde normalmente é usado o dinheiro, não há vínculo entre quem efetua a troca: o comprador e o vendedor. No ato de presentear, há um componente afetivo e relacional (BELK, 2007).

O compartilhamento é mais comum entre familiares e amigos do que entre estranhos. Quando o compartilhamento é um ato inclusivo, direcionado a tornar o receptor parte de uma pseudo-família, é descrito como compartilhamento para dentro (sharing in). Quando o ato de compartilhar envolve estranhos ou é um ato isolado como dar uma informação a alguém, é descrito como compartilhamento para fora (sharing out) (BELK, 2014).

Belk (2010) teoriza sobre os tipos de compartilhamento mais frequentes, o demandado (demand sharing) e o aberto (open sharing). O primeiro se dá quando as crianças pedem para ser alimentadas. O segundo ocorre quando se diz a um hóspede "minha casa é sua", e ele tem a liberdade de usar todos os recursos ali envolvidos, alimentos, móveis. O autor defende que o compartilhamento para dentro é o tipo mais comum, já que dificilmente o ato de compartilhar ocorre entre estranhos.

Após argumentar sobre compartilhamento, Belk (2014) examina atualizações acerca do tema e práticas relacionadas que, segundo o autor, não envolvem o verdadeiro compartilhamento. Nesse contexto, estariam inseridos os modelos de negócio facilitados pela internet (internet facilited sharing) e o consumo colaborativo (collaborative consumption).

$\mathrm{Na}$ última década, o verbo compartilhar tornou-se muito popular. A evolução da internet proporcionou um fenômeno nunca antes experimentado em tão larga escala. Ideias e opiniões, fotos, músicas, conhecimento e tempo tornaram-se objetos de compartilhamento. Compartilha-se ainda carros, bicicletas, moradias e dinheiro. Os motivos para compartilhar são diversos e dependem do objeto, de seus significados e dos atores envolvidos no fenômeno (BELK, 2014).

A internet não apenas tem oportunizado o surgimento de novas maneiras para compartilhar como tem proporcionado que antigas formas de compartilhamento alcancem larga escala. Na rede, a maioria dos modelos não 
envolvem compensação como os sites de compartilhamento de fotos e as redes sociais, como Pinterest e Facebook, sites que avaliam serviços como o TripAdvisor, e os sites nos quais os usuários podem compartilhar conhecimento para a construção de seus conteúdos, como Wikipedia e Linux (BELK, 2014).

A outra variação sobre o tema compartilhamento, segundo Belk (2014) é o consumo colaborativo, definido pelo autor como sendo formado por pessoas coordenando a aquisição e distribuição de um recurso por um valor ou outra compensação. Por outra compensação, a definição também abrange permuta, negociação e troca, envolvendo a concessão e recebimento de compensações não monetárias. E exclui atividades de compartilhamento que não possuem compensação envolvida e 0 ato de presentear, onde há a transferência permanente de propriedade.

Botsman e Rogers (2010) ampliam a utilização dos conceitos descritos por Belk (2007, 2010). O conceito de consumo colaborativo definido pelos autores envolve o compartilhamento, as trocas, os empréstimos, as negociações, os aluguéis, as doações e as permutas. São apresentados diversos exemplos de empresas de compartilhamento de carros, bicicletas, tempo, brinquedos, acomodação, dinheiro, serviços, envolvendo ou não a compensação de formas diversas, seja ela monetária ou através de outra modalidade.

Dentre os vários exemplos citados pelos autores, destacam-se dois, que possuem a mesma finalidade, mas são distintos no que tange à forma de compensação envolvida: O primeiro exemplo é o da empresa Airbnb que, se descreve, em sua página da internet como "um mercado comunitário confiável para pessoas anunciarem, descobrirem e reservarem acomodações únicas ao redor do mundo, seja de um computador, de um celular ou de um tablet" (BOTSMAN; ROGERS, 2010). O segundo exemplo é o da empresa CouchSurfing que se apresenta através do texto: "Nós imaginamos um mundo melhor feito por viagens e viagens tornadas mais ricas por conexão. CouchSurfers compartilham suas vidas com as pessoas que encontram, promovendo o intercâmbio cultural e o respeito mútuo" (COUCHSURFING, 2018).

Enquanto no Airbnb a compensação se dá através do pagamento feito pelo usuário do serviço ao proprietário do imóvel, o provedor do serviço, com o repasse de uma taxa aos proprietários da plataforma, no CouchSurfing, não há nenhum tipo de compensação nem aos proprietários e nem aos gestores da plataforma. As duas modalidades, estariam enquadradas na definição de consumo colaborativo de Botsman e Rogers (2010). Contudo, de acordo com o conceito de Belk (2014), nem o Airbnb nem o CouchSurfing seriam considerados consumo 
colaborativo, já que no primeiro, há compensação monetária e no segundo, não há compensação envolvida.

Aprende-se a compartilhar ainda na infância quando os pais estimulam que a criança compartilhe seus brinquedos com amigos ou irmãos. À medida que o ser humano cresce, ele vai compartilhando menos e se tornando mais individualista (BOTSMAN; ROGERS, 2010).

O consumo colaborativo possui três categorias distintas: na primeira os consumidores pagam uma taxa para compartilhar recursos. Nessa categoria estão incluídas plataformas de aluguel de produtos como a Rent a Toy, onde o usuário paga uma assinatura mensal e recebe brinquedos prontos para uso, devolvendoos ao final do período contratado. Os autores destacam algumas vantagens da categoria, entre elas, não precisar comprar brinquedos novos para cada fase da criança e o aproveitamento de espaço. A segunda categoria seriam os mercados de redistribuição, onde os consumidores compram e vendem produtos usados. Aqui, encontram-se empresas como o eBay e OLX. Uma das vantagens é o aumento da vida útil do bem. A terceira categoria está relacionada a estilos de vida, onde consumidores buscam uma nova forma de consumo, ligada ao estilo de uso e acesso a produtos e serviços, o compartilhamento. Aqui, estaria inserida a marca Uber (BOTSMAN; ROGERS, 2010).

Em artigo publicado a posteriori, Belk (2014) considera muito abrangente o conceito de Botsman e Rogers (2010) para consumo colaborativo, já que os exemplos citados pelos autores abarcam não apenas modalidades de compartilhamento, como também o ato de presentear a troca de bens, protótipos distintos, segundo o autor.

Sendo uma modalidade de troca, Benoit et al. (2017) entendem que o consumo colaborativo é uma relação entre três atores: o provedor do serviço, o provedor da plataforma e o usuário do serviço. Tomando a Uber como exemplo, esses papéis seriam representados pelo motorista, a empresa e o consumidor, respectivamente. No modelo proposto, foram destacados os motivos para engajamento na modalidade de consumo, as atividades, os recursos e as capacidades, para cada um dos atores. Aqui, trataremos dos motivos, conforme descrito na Tabela 1. 


\begin{tabular}{|l|l|l|}
\hline \multicolumn{1}{|c|}{ Usuário do Serviço } & \multicolumn{1}{|c|}{ Provedor do Serviço } & Provedor da Plataforma \\
\hline Motivos econômicos & Motivos econômicos & Ganhos econômicos \\
Motivos sociais & Liberdade para & Inovação e reação ao \\
Valores hedônicos & empreender & mercado \\
Redução de riscos & Motivos sociais & Construção de relações \\
e responsabilidades & & benéficas \\
Benefícios ambientais & & \\
\hline
\end{tabular}

Tabela 1: Motivos para engajamento em serviços do consumo colaborativo

Fonte: Elaboração própria. Adaptado de Benoit et al. (2017)

Para o consumidor, os motivos econômicos, relacionados à redução de custos, exercem um importante papel na decisão em usar um serviço de consumo colaborativo. Os motivos sociais são associados ao pertencimento, à criação de laços sociais. Os valores hedônicos referem-se a oportunidades de satisfação de necessidades hedônicas, como por exemplo, o desejo por status. A redução de riscos e responsabilidades está associada à não propriedade, considerando, por exemplo, que possuir um carro acarreta riscos e responsabilidades. E, por fim, os benefícios ambientais estão associados ao impacto positivo que sua decisão terá sobre o ambiente (BENOIT et al., 2017).

Bardhi e Eckhardt (2012) denominam de consumo baseado no acesso (acess-based consumption), a modalidade de consumo mediada pelo mercado onde não há transferência de propriedade, contrapondo esse conceito ao conceito de propriedade e ao de compartilhamento, ampliando a utilização desse último.

O consumo baseado no acesso é delineado por seis dimensões: a temporalidade, o anonimato, a mediação pelo mercado, o envolvimento do consumidor, o tipo de objeto acessado e a motivação política para consumir. $\mathrm{O}$ objeto do estudo, uma plataforma de compartilhamento de carros (car sharing) estaria enquadrado nessa modalidade de consumo, distinta do compartilhamento e também da propriedade (BARDHI; ECKHARDT, 2012).

Para Belk (2010), o acesso é similar ao compartilhamento, uma vez que não há a transferência de propriedade. Os conceitos se diferenciam quanto ao sentimento de propriedade percebido. Enquanto no conceito de compartilhamento, há sentimento de propriedade compartilhada por um determinado bem, no conceito de acesso isso não ocorre, uma vez que o bem é apenas usufruído, e quem o utiliza não tem o sentimento de que aquele bem é uma posse sua. Ele apenas "ganha o direito" de usá-lo sob alguma forma de compensação. $O$ acesso também pode ser obtido mediante uma troca econômica, quando o usuário paga uma taxa ao provedor do serviço para utilizar o bem (BARDHI; ECKHARDT, 2012).

Relacionando o consumo colaborativo ao conceito de não-propriedade, Lindblom e Lindblom (2017) definem como orientação à não propriedade (de- 
ownership orientation) a importância que um indivíduo dedica ao ato de compartilhar produtos e serviços em vez de comprá-los ou de possuí-los. $\mathrm{Na}$ orientação à não propriedade, os consumidores atribuem mais valor ao acesso aos recursos e preferem aproveitar os produtos e as experiências sem os riscos e aborrecimentos da propriedade permanente.

Tal orientação estaria relacionada positivamente ao consumo colaborativo, ou seja, o quanto mais forte é a orientação à não propriedade, mais propenso o indivíduo está a praticar o consumo colaborativo. Contraditoriamente, os achados da pesquisa indicam ainda que as gerações mais jovens, com 45 anos ou menos, tendem a possuir uma maior inclinação à não propriedade e que, embora considerem o ato de colaborar relevante, poucos o praticam de fato (LINDBLOM; LINDBLOM, 2017).

John (2012) relaciona o compartilhamento e o consumo colaborativo à tecnologia, especificamente à internet, aos dispositivos móveis (smartphones) e às redes sociais. Formas não institucionalizadas de compartilhamento são observadas há bastante tempo, coexistindo com o capitalismo tradicional - vide os brechós de roupas usadas, os jornais especializados em vendas de produtos usados, as comunidades hippies da década de 60. O que distingue o consumo colaborativo praticado no século XXI é sua afinidade com as tecnologias de comunicação. A tecnologia atua como viabilizador e também como direcionador para a prática.

Como viabilizador, observa-se que a internet é o principal canal de comunicação para as plataformas, comunidades e práticas de consumo colaborativo. A tecnologia também possui a capacidade de acelerar projetos relacionados ao tema que tenham sido iniciados de forma off-line. Como direcionador, nota-se que as pessoas estão reproduzindo comportamentos online em comportamentos off-line. $O$ ato de compartilhar na rede está fazendo com que as pessoas tenham comportamentos semelhantes fora dela, fazendo com que mudem seus modos de consumo, retomando hábitos antigos. As redes sociais trazem de volta a importância do conceito de comunidade (JOHN, 2012).

A tecnologia também é considerada viabilizadora na perspectiva de Piscicelli, Cooper e Fisher (2015) que definem o consumo colaborativo como um modelo socioeconômico emergente baseado na partilha, no aluguel, na doação, nas trocas, permutas e empréstimos que se torna possível através da interação de comunidades e do uso de tecnologias em rede. Para os autores, trata-se de uma modalidade mais sustentável de consumo uma vez que tem o potencial de 
evitar novas compras, intensificar o uso do que está ocioso e promover a reutilização de produtos que seriam descartados.

Barnes e Mattson (2016) consideram o consumo colaborativo uma alternativa ao hiperconsumo e à propriedade tradicional, onde a lógica do uso e do acesso se sobrepõe à da posse. Os autores previram que o crescimento da economia compartilhada vai provocar uma mudança radical nas compras e no consumo dos indivíduos, tanto online como off-line. Eles apontam, no entanto, que o sucesso das empresas de consumo colaborativo depende da formação de comunidades leais e com afinidade à atividade de compartilhamento, reforçando o que já havia sido postulado por Botsman e Rogers (2010): que o compartilhamento entre pares promove o ressurgimento da comunidade, onde as pessoas podem confiar umas nas outras.

O senso de comunidade também é destaque no conceito de consumo colaborativo de Vaquero e Calle (2013) uma vez que, segundo as autoras, tal forma de consumo promove a cooperação entre pessoas e reforça o sentimento de compromisso, tornando o aspecto social mais relevante e importante.

Albinsson e Perera (2012) denominam de consumo alternativo, as atividades de colaboração, compartilhamento e de não consumo que não envolvem a troca monetária, explorando os espaços RRFMs (really, really, free markets) inicialmente criados como forma de resistência ao capitalismo, mas hoje usados por comunidades e até por cidades para promover a conscientização sobre sustentabilidade e consumo excessivo. Seu estudo busca responder a questionamentos propostos por Belk (2010) sobre o que pode ser feito para encorajar o compartilhamento de recursos que são desperdiçados, por que e como os indivíduos resistem a práticas de consumo, quem são esses indivíduos e quais os significados que dão a essa prática, explorando o consumo colaborativo em ambientes onde, além de não haver a troca monetária, há interação física entre os participantes.

O conceito de comunidade, que pressupõe relações de confiança entre seus membros, foi encontrado com frequência na literatura pesquisada. Outros conceitos encontrados foram o de inovação, o de confiança, o de reciprocidade $e$ o de não-propriedade. A Tabela 2 exibe um resumo das definições ou discussões encontradas durante a revisão de literatura, bem como os conceitos presentes nas discussões. 


\begin{tabular}{|c|c|c|c|c|}
\hline Autor & $\begin{array}{l}\text { Termo } \\
\text { Usado }\end{array}$ & Definição ou discussão & $\begin{array}{l}\text { Mediação } \\
\text { pelo } \\
\text { mercado }\end{array}$ & $\begin{array}{l}\text { Conceitos } \\
\text { evidentes }\end{array}$ \\
\hline $\begin{array}{l}\text { FELSON; } \\
\text { SPAETH } \\
(1978)\end{array}$ & $\begin{array}{l}\text { Consumo } \\
\text { colaborativo }\end{array}$ & $\begin{array}{l}\text { Eventos onde uma ou mais } \\
\text { pessoas consumiam bens e } \\
\text { serviços, engajadas em atividades } \\
\text { conjuntas com uma ou mais } \\
\text { pessoas. }\end{array}$ & Não & Engajamento \\
\hline $\begin{array}{l}\text { BELK } \\
(2007)\end{array}$ & $\begin{array}{l}\text { Compartilha } \\
\text { mento }\end{array}$ & $\begin{array}{l}\text { O ato e o processo de distribuir o } \\
\text { que é nosso para outros para seu } \\
\text { uso e/ou o ato e o processo de } \\
\text { receber ou tomar algo de outros } \\
\text { para nosso próprio uso. }\end{array}$ & Não & Comunidade \\
\hline $\begin{array}{l}\text { BELK } \\
(2014)\end{array}$ & $\begin{array}{l}\text { Consumo } \\
\text { colaborativo }\end{array}$ & $\begin{array}{l}\text { Pessoas coordenando a aquisição } \\
\text { e distribuição de um recurso por } \\
\text { um valor ou outra compensação, } \\
\text { abrangendo permuta, negociação } \\
\text { e troca, envolvendo a concessão e } \\
\text { recebimento de compensações } \\
\text { não monetárias. }\end{array}$ & Sim & Reciprocidade \\
\hline $\begin{array}{l}\text { BOTSMAN; } \\
\text { ROGERS } \\
(2010)\end{array}$ & $\begin{array}{l}\text { Consumo } \\
\text { colaborativo }\end{array}$ & $\begin{array}{l}\text { Envolve o compartilhamento, as } \\
\text { trocas, os empréstimos, } \\
\text { negociações, aluguéis, doações e } \\
\text { permutas, com ou sem } \\
\text { compensação monetária. }\end{array}$ & Sim & $\begin{array}{l}\text { Comunidade } \\
\text { Confiança } \\
\text { Inovação }\end{array}$ \\
\hline $\begin{array}{l}\text { ALBINSSON; } \\
\text { PERERA } \\
(2012)\end{array}$ & $\begin{array}{l}\text { Consumo } \\
\text { Alternativo }\end{array}$ & $\begin{array}{l}\text { Atividades de colaboração, } \\
\text { compartilhamento e de não } \\
\text { consumo que não envolvem a } \\
\text { troca monetária. }\end{array}$ & Não & Comunidade \\
\hline $\begin{array}{l}\text { BARDHI; } \\
\text { ECKHARD } \\
\text { (2012) }\end{array}$ & $\begin{array}{l}\text { Consumo } \\
\text { baseado no } \\
\text { acesso }\end{array}$ & $\begin{array}{l}\text { Modalidade onde não há } \\
\text { transferência de propriedade. }\end{array}$ & Sim & $\begin{array}{l}\text { Confiança } \\
\text { Não } \\
\text { propriedade }\end{array}$ \\
\hline $\begin{array}{l}\text { JOHN } \\
(2012)\end{array}$ & $\begin{array}{l}\text { Consumo } \\
\text { colaborativo }\end{array}$ & $\begin{array}{l}\text { Modalidade na qual a tecnologia } \\
\text { atua como viabilizador e também } \\
\text { como direcionador para a prática. }\end{array}$ & Sim & $\begin{array}{l}\text { Confiança } \\
\text { Inovação }\end{array}$ \\
\hline $\begin{array}{l}\text { VAQUERO; } \\
\text { CALLE } \\
(2013)\end{array}$ & $\begin{array}{l}\text { Consumo } \\
\text { colaborativo }\end{array}$ & $\begin{array}{l}\text { Forma de consumo que promove a } \\
\text { cooperação entre pessoas } \\
\text { desperta o senso de comunidade, } \\
\text { reforçando o sentimento de } \\
\text { compromisso. }\end{array}$ & Não & Comunidade \\
\hline $\begin{array}{l}\text { PISCICELLI; } \\
\text { COOPER; } \\
\text { FISCHER } \\
(2015)\end{array}$ & $\begin{array}{l}\text { Consumo } \\
\text { colaborativo }\end{array}$ & $\begin{array}{l}\text { Modelo baseado na partilha, no } \\
\text { aluguel, na doação, nas trocas, } \\
\text { permutas e empréstimos. E } \\
\text { possível através da interação de } \\
\text { comunidades e do uso de } \\
\text { tecnologias em rede. }\end{array}$ & Sim & $\begin{array}{l}\text { Comunidade } \\
\text { Inovação }\end{array}$ \\
\hline $\begin{array}{l}\text { LEVY } \\
(2015)\end{array}$ & $\begin{array}{l}\text { Compartilha } \\
\text { mento }\end{array}$ & $\begin{array}{l}\text { O compartilhamento familiar pode } \\
\text { envolver reciprocidade e troca } \\
\text { financeira. }\end{array}$ & Não & Reciprocidade \\
\hline $\begin{array}{l}\text { BARNES; } \\
\text { MATTSSON } \\
(2016)\end{array}$ & $\begin{array}{l}\text { Consumo } \\
\text { colaborativo }\end{array}$ & $\begin{array}{l}\text { Depende da formação de } \\
\text { comunidades leais e que possuam } \\
\text { afinidade com a atividade de } \\
\text { compartilhamento. }\end{array}$ & Não & Comunidade \\
\hline $\begin{array}{l}\text { BENOIT et al. } \\
(2017)\end{array}$ & $\begin{array}{l}\text { Consumo } \\
\text { colaborativo }\end{array}$ & $\begin{array}{l}\text { Trata-se de uma relação de troca } \\
\text { que envolve três atores: o } \\
\text { provedor do serviço, o provedor da } \\
\text { plataforma e o consumidor. }\end{array}$ & Sim & Reciprocidade \\
\hline $\begin{array}{l}\text { LINDBLOM; } \\
\text { LINDBLOM } \\
(2017)\end{array}$ & $\begin{array}{l}\text { Consumo } \\
\text { colaborativo }\end{array}$ & $\begin{array}{l}\text { O quanto mais forte é a orientação } \\
\text { à não propriedade, mais propenso } \\
0 \text { indivíduo está a praticar o } \\
\text { consumo colaborativo. }\end{array}$ & Sim & $\begin{array}{l}\text { Não } \\
\text { propriedade }\end{array}$ \\
\hline
\end{tabular}

Tabela 2: Resumo das definições e discussões encontradas na literatura

Fonte: Elaboração própria 


\section{2.}

\section{A marca na perspectiva da semiótica francesa}

\subsection{1.}

\section{Semiótica discursiva de linha francesa}

A semiótica discursiva de linha francesa, ou semiótica greimasiana, foi desenvolvida na década de 1960 por pesquisadores franceses, reunidos ao redor de Algirdas Greimas (PESSÔA, 2013). A teoria semiótica é uma teoria da significação cuja preocupação inicial é explicitar, sob a forma de construção conceitual, as condições da apreensão e da produção de sentido (GREIMAS; COURTÉS, 2008).

Mick (1986) afirma que a semiótica analisa a estrutura de eventos produtores de significados, tanto verbais como não-verbais e Floch (1993) define semiótica como uma relação concreta com o sentido, dirigida a tudo que tem sentido. Pode ser um texto, um logotipo, um filme, um cartaz, um comportamento, todos considerados objetos de sentido.

Todo objeto de sentido é considerado um texto para a teoria semiótica, tornando-se seu objeto de estudo. Barros $(2005,2008)$ postula que a semiótica se preocupa com o texto com o objetivo de descrever o que o texto diz, o sentido, e explicar como o texto faz para dizer o que diz, ou seja, o que é usado no texto para construção do sentido.

Floch (2001) compreende que para a semiótica, o sentido é formado pela união de dois planos da linguagem, o plano de expressão, no qual as qualidades sensíveis da linguagem são selecionadas e articuladas entre si; e o plano de conteúdo, no qual surge a significação a partir das variações de cada cultura, que encadeia valores e discursos em prol da criação de sua visão de mundo.

O plano de conteúdo e o plano de expressão são interdependentes e é através de sua união que se forma o texto, um produto da manifestação de um plano de conteúdo através de um plano de expressão (FIORIN, 2016).

A semiótica busca explicar os sentidos do texto focando inicialmente em explicitar o plano de conteúdo desse texto, através do percurso gerativo da significação (BARROS, 2005), modelo proposto por Greimas e Courtés (2008), para analisar o sentido dos textos. Tal percurso pode ser considerado "um modelo teórico da significação em um nível de generalidade que permite abordar toda a produção humana significativa, verbal e não verbal" (PESSÔA; SANT'ANA; MELLO, 2015 p. 72) e definido como "um modelo que simula a produção e a interpretação do significado, do conteúdo" (FIORIN, 2016, p. 44). 
Barros (2005) apresentou o percurso de forma resumida, como se segue:

a) O percurso parte do nível mais simples e abstrato ao mais complexo e concreto. Os elementos que se manifestam na superfície do texto já estão enriquecidos e concretizados e provêm de relações semânticas mais simples e abstratas;

b) Formam-se três etapas no percurso, sendo que o sentido do texto depende da relação entre os níveis;

c) O primeiro nível, o mais simples e abstrato, é o nível fundamental e nele a significação se apresenta como uma oposição semântica;

d) O segundo nível, o narrativo, é onde a narrativa se constitui sob o ponto de vista de um sujeito que sai em busca de valores;

e) O último nível, o discursivo, é o mais complexo e concreto, onde a narrativa vai se tornar discurso, através dos procedimentos de temporalização, espacialização, actorialização, tematização e figurativização.

Cabe destacar ainda que, "em cada um dos níveis do percurso gerativo, há um componente sintático e outro semântico" (PESSÔA; SANT'ANA; MELLO, 2015 , p. 72). Fiorin (2016, p. 20) faz a distinção entre sintaxe e semântica postulando que "a sintaxe é mais autônoma que a semântica, na medida em que uma mesma relação sintática pode receber vários investimentos semânticos."

No nível discursivo, a sintaxe vai introduzir o tempo e o espaço e a semântica utilizará os procedimentos de tematização e figurativização, acrescentando sentido ao discurso (PESSÔA; SANT'ANA; MELLO, 2015).

O sentido do texto depende da relação entre os três níveis do percurso gerativo da significação, no entanto é possível observá-los de forma separada, já que cada um possui uma gramática independente. (PESSÔA, 2013).

O discurso é uma unidade do plano de conteúdo, na qual as formas narrativas abstratas são envolvidas por elementos concretos (FIORIN, 2016) e "a enunciação é o ato de produção do discurso" (FIORIN, 2016, p. 55).

\subsection{2.}

\section{A característica semiótica das marcas}

Semprini (2010, p. 96) define marca como "um conjunto de discursos relativos a ela pela totalidade dos sujeitos (individuais e coletivos) envolvidos em sua construção". E ainda, a marca é "uma instância semiótica, uma maneira de segmentar e de atribuir sentido de forma ordenada, estruturada e voluntária". Tal 
definição amplia e atualiza o conceito propostos por Aaker (1998), e a definição da Associação Americana de Marketing, apresentada por Kotler e Keller (2011):

\begin{abstract}
Uma marca é um nome diferenciado e/ou símbolo (tal como um logotipo, marca registrada, ou desenho de embalagem) destinado a identificar os bens ou serviços de um vendedor ou de um grupo de vendedores e a diferenciar esses bens e serviços daqueles dos concorrentes. Assim uma marca sinaliza aos consumidores a origem do produto e protege tanto 0 consumidor quanto 0 fabricante, dos concorrentes que ofereçam produtos que pareçam idênticos (AAKER, 1998, p. 7);

Uma marca é um nome, termo, sinal, símbolo ou design, ou uma combinação deles, destinada a identificar os bens ou serviços de um vendedor ou grupo de vendedores e diferenciá-los dos concorrentes. Um produto ou serviço cujas dimensões o diferenciam de outros produtos ou serviços projetados para satisfazer a mesma necessidade. Tais diferenças podem ser funcionais, racionais ou tangíveis relacionadas ao desempenho do produto ou podem ser mais simbólicas, emocionais ou intangíveis - relacionadas ao que a marca representa ou significa em um sentido mais abstrato (KOTLER; KELLER, 2011, p. 241).
\end{abstract}

Ao referir-se à marca como um conjunto de discursos, Semprini (2010) se aproxima do conceito apresentado por Sherry Jr. (2006, p. 42), que identifica a marca como um repositório de significados na cultura do consumidor e "como um empreendimento semiótico da empresa".

Para Semprini (2010, p. 47), "a marca é, de certa forma, a instância que fornece um contexto dotado de sentido a uma experiência ou a um imaginário que, sozinhos, tenderiam a ser imprecisos ou muito abstratos".

A natureza semiótica da marca para Semprini (2010), é a sua capacidade em construir e propagar significados que podem estar organizados em narrativas estruturadas, como as encontradas na publicidade, mas podem ser difundidos por outras manifestações da marca, que funcionam também como atos discursivos, encontrando-se aí a "verdadeira natureza da marca" (SEMPRINI, 2010, p. 98):

Como instância semiótica, a marca estabelece um projeto de sentido, capaz de estabelecer uma relação e um contrato com o consumidor. Este reage à capacidade da marca de criar mundos possíveis, congruentes com seus projetos de vida (PESSÔA; SANT'ANA; MELLO, 2015, p. 73).

O desafio para as marcas pós-modernas reside, então, em construir projetos que tenham coerência entre as suas narrativas estruturadas e todas as manifestações que ocorrem ao longo do tempo.

O modelo Projeto/Manifestações de marca proposto por Semprini (2010), e que serve de referência metodológica para esta dissertação, foi desenvolvido sob influência dos trabalhos de Jean Marie Floch, pioneiro na aplicação da semiótica francesa no campo do marketing.

O projeto de marca abrange elementos relacionados à estratégia da marca, decisões de produtos, canais, mercados. Ao se observar a marca em um contexto 
de mercado pós-moderno, é necessário ampliar e considerar que esse projeto deve "propor um horizonte de sentido, uma proposição de tipo semiótica e sociocultural que seja original, pertinente e atraente para um determinado público" e que faça sentido para esse público (SEMPRINI, 2010, p. 146).

Semprini (2010, p. 149) distingue cinco componentes no projeto de marca: "a enunciação fundamental, a promessa, a especificação da promessa, a inscrição de um território e os valores".

A enunciação fundamental é a razão de ser da marca, a justificativa de sua existência. É a partir daí que a marca edifica sua legitimidade no sistema semiótico. A enunciação transforma-se em promessa, quando a marca orienta sua enunciação para o público, destacando suas as vantagens. As competências da empresa, sua cultura, podem ser utilizadas na construção da promessa (SEMPRINI, 2010).

A especificação da promessa consiste em tornar a promessa única, diferente, original, de forma que consiga se diferenciar da concorrência. $\mathrm{Na}$ sequência inscreve-se a promessa em um território concreto, ou seja, gerando uma oferta concreta de produtos e serviços (SEMPRINI, 2010).

Por fim, o último componente do projeto de marca são os seus valores, as características que dão atitude à marca (SEMPRINI, 2010).

Ao analisar a publicidade francesa de automóveis da década de 1980, Floch (1993) organizou os valores da sociedade de consumo, construindo uma axiologia do consumo (Figura 2), a partir da definição de Greimas de valor de uso e valor de base (PESSÔA, 2013):

Por valor de base, entende-se um dos valores que correspondem ao plano das preocupações fundamentais do ser e cuja busca sustenta a vida e dá sentido a múltiplos programas de ação secundários, mais superficiais ou mais "práticos" (PESSÔA, 2013, p. 121).

No caso da publicidade de automóveis analisada, quando o carro representa a identidade de seu condutor, seu status social, sua virilidade, diz-se que ele está investido de um valor de base. Em contrariedade, quando são evidenciados na publicidade, aspectos relativos à dirigibilidade, à confiabilidade, ao conforto do automóvel, ele estaria investido de valores de uso. A partir daí, são definidos quatro grandes tipos de valorização, conforme descrito por Pessôa (2013, p. 123 e 124): 
$\checkmark$ Valorização prática: são os valores de uso concebidos como contrários aos valores de base. Podem ser denominados também de valores utilitários.

$\checkmark$ Valorização utópica: corresponde aos valores de base concebidos como contrários aos valores de uso. Também denominados valores existenciais. O termo utópico é utilizado no modelo com o sentido de "visão de um objetivo" ou do que é desejado, e não no sentido ilusório.

$\checkmark$ Valorização lúdica: são os valores de base que correspondem à negação dos valores práticos ou utilitários. O termo lúdico tem o sentido de "atividade livre por excelência".

Valorização crítica: valores de uso que correspondem à negação dos valores existenciais ou utópicos. Nesse tipo de valorização, estão presentes aspectos lógicos que permitem a objetividade.

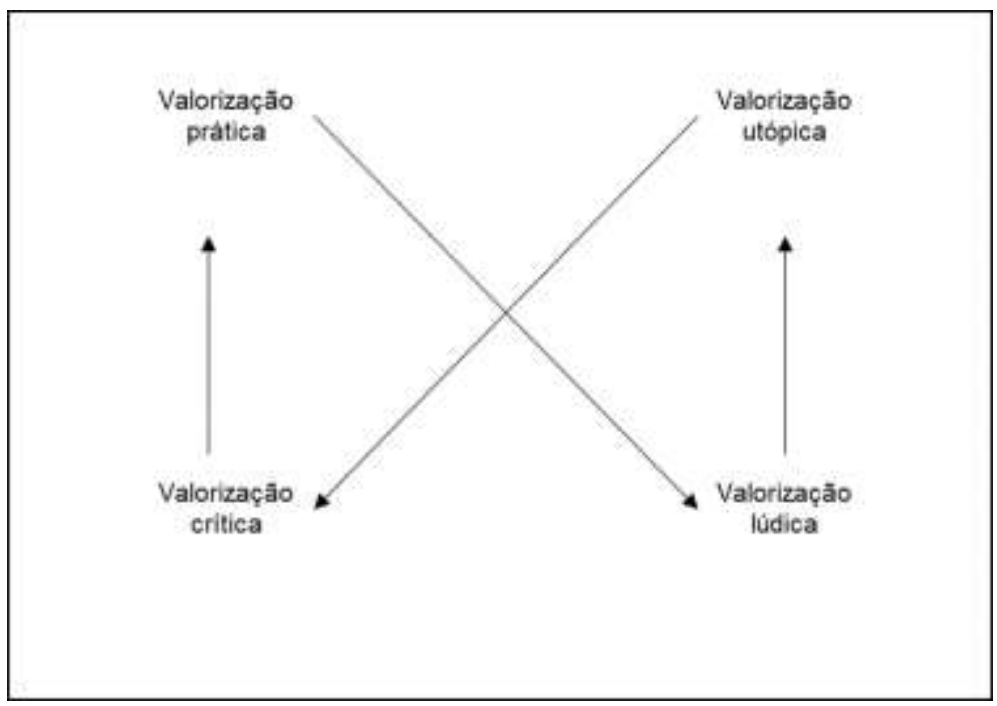

Figura 2: Axiologia do consumo Fonte: Floch (1983, p. 148)

É através dos valores que são escolhidas as manifestações da marca. As manifestações são os enunciados que concretizam o projeto da marca e compreendem as dimensões materiais e imateriais pelas quais a marca se torna perceptível aos destinatários e ao contexto (SEMPRINI, 2010). Como manifestações podem ser considerados o nome, a embalagem, a identidade visual, o ponto de venda, eventos, entre outros elementos do mix de marketing. Cada marca terá um conjunto de manifestações individuais que terão pesos diferentes ao serem utilizadas para explicitar o projeto da marca e em seu impacto concreto junto ao público. O projeto de marca está ligado à esfera do inteligível, enquanto que as manifestações estão vinculadas à esfera do sensível e é através 
da análise do conjunto de manifestações de uma marca, que é possível entender sua identidade manifesta (SEMPRINI, 2010).

O processo de construção semiótico de uma marca se dá em dois sentidos, o primeiro sob o ponto de vista do projeto de marca, no sentido descendente e o outro, sob o ponto de vista do público da marca, inverso e ascendente. Ao ser exposto às manifestações da marca, o público as interpreta e reconstitui o denominado projeto de marca manifesto, como mostra a Figura 3. É somente através das manifestações que o público conhece o projeto de uma marca (SEMPRINI, 2010).

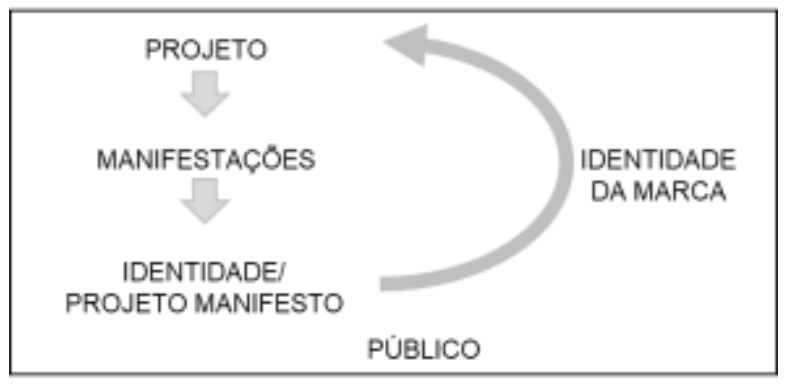

Figura 3: A identidade de marca

Fonte: adaptado de Semprini (2010, p. 162)

A descrição da identidade da marca é feita a partir da análise de cada manifestação da marca, de forma individual e posteriormente, da união dessas análises parciais. Cada manifestação é então considerada um enunciado, uma estrutura semiótica e, para compreendê-la, aplica-se o modelo de análise semionarrativo (SEMPRINI, 2010), conforme Figura 4.

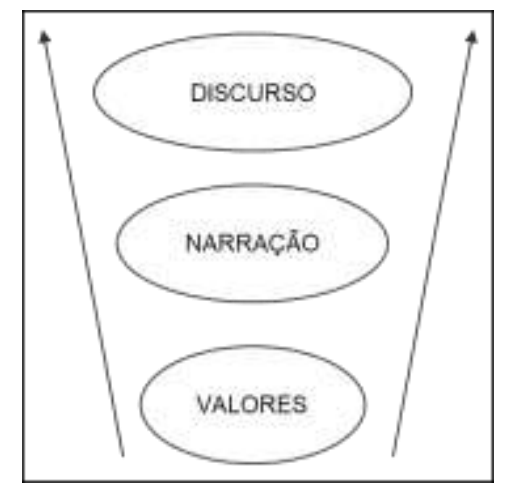

Figura 4: A organização semionarrativa do significado Fonte: Semprini (2010, p. 154)

Tal modelo segue o percurso gerativo de sentido descrito no tópico anterior. Os valores representam o nível mais profundo, e estariam relacionados aos valores que estruturam uma sociedade. É nesse nível que se encontram os valores fundadores da identidade, atribuindo à marca um projeto, um sentido e uma duração. São esses valores que vão assegurar a legitimidade da marca junto 
ao público-alvo. A narração representa o nível intermediário, narrativo, onde os valores são organizados sob a forma de relatos ou histórias. O terceiro nível é o do discurso ou das manifestações, onde se localizam os aspectos perceptíveis da marca, como a sua logomarca, suas embalagens, entre outras manifestações (SEMPRINI, 2010).

O processo de criação de significado para uma marca é modelado pelos contextos histórico e sociocultural, contexto de consumo, as ações da concorrência, contexto de comunicação e pelas informações que os receptores dispõem. Dessa forma, esses elementos influenciam os processos interpretativos e as atribuições de sentido às manifestações da marca (SEMPRINI, 2010).

Acredita-se que, ao adotar a característica semiótica da marca para a análise da marca Uber, por meio de seu projeto recomposto e de sua identidade manifesta, através dos discursos dos consumidores, este estudo leva em consideração as três dinâmicas distintas que compõem a marca pós-moderna, a produção, a recepção e o contexto, ajustando-se às perspectivas de Semprini (2010) e de Floch (1993). Como o consumo colaborativo é um fenômeno recente, faz-se justificada a adoção da semiótica na condução epistemológica e metodológica (PESSÔA, 2013). 


\section{3 \\ Método}

Este capítulo apresenta a metodologia escolhida para a pesquisa, definindo o tipo de estudo realizado e está dividido em quatro itens: o tipo de pesquisa, os passos metodológicos que foram seguidos, a composição do corpus de pesquisa e as limitações do método.

\section{1.}

\section{Perspectiva qualitativo-interpretativa}

Considerando a natureza do fenômeno ora estudado, optou-se pela abordagem qualitativo-interpretativa, de natureza exploratória, que se caracteriza pela versatilidade e flexibilidade (MALHOTRA, 2004). "O objetivo da pesquisa exploratória é explorar ou fazer uma busca em um problema ou em uma situação a fim de oferecer informações e maior compreensão" (MALHOTRA, 2004, p.59).

Aqui, cabe oferecer mais informações sobre a construção do problema de pesquisa do presente trabalho. Inicialmente, o objetivo estabelecido era analisar os significados do conceito de consumo colaborativo para os consumidores brasileiros. Entretanto, a pesquisa de campo conduzida por meio de entrevistas pessoais apontou para um grande volume de conteúdo acerca da marca Uber. Dentre as empresas citadas anteriormente na delimitação, a marca Uber destacou-se, sendo o foco principal das preocupações, da avaliação e dos próprios significados de consumo colaborativo dos entrevistados. Dessa maneira, julgou-se interessante ampliar o problema de pesquisa inicialmente estabelecido. Manteve-se a questão do significado de consumo colaborativo no contexto da questão central e esta foi complementada com o significado da marca Uber, em especial e das aproximações e afastamentos do projeto que esta marca enuncia, em relação às interpretações dos consumidores (estudo de recepção).

Para responder à pergunta central de pesquisa, bem como atingir os objetivos intermediários que dela derivaram, foram adotados os passos metodológicos descritos no próximo tópico. 


\section{2. \\ Passos Metodológicos}

Concluída a revisão da literatura, partiu-se para a coleta dos dados, que consistiu na estruturação do roteiro de entrevistas, na reunião de informações sobre as empresas Uber e Airbnb e na realização das entrevistas. As marcas foram escolhidas por atuarem no Brasil e por serem identificadas como protagonistas do consumo colaborativo, por alguns dos autores estudados. Após a ampliação do problema de pesquisa, descrita no tópico anterior, optou-se por manter o material sobre a Airbnb, para não caracterizar, para os entrevistados, que se tratava de um estudo dedicado a investigar a marca Uber, em particular.

Para entendimento do conceito de consumo colaborativo na perspectiva dos consumidores, foi utilizada a análise de conteúdo (BARDIN, 1977). A percepção encontrada foi difusa e a grade para categorização foi elaborada de forma a correlacionar as evidências com os conceitos presentes na literatura, sendo caracterizada como uma grade fechada (BARDIN, 1977).

Logo nas primeiras entrevistas, para as quais foram levados materiais de estímulo das marcas Uber e Airbnb, a marca Uber demonstrou ser um objeto de estudo que justificaria a ampliação do escopo da pesquisa.

O segundo passo foi a recomposição do projeto da marca Uber, aplicando o modelo Projeto/Manifestação de identidade de marca (SEMPRINI, 2010), sob a perspectiva teórica da semiótica discursiva de linha francesa (GREIMAS; COURTÉS, 2008), seguindo as reflexões sobre a contribuição da semiótica para os estudos de marketing propostas por Pessôa (2013).

Foram escolhidas como fontes para essa fase, as informações do site oficial brasileiro e a campanha publicitária "Confiança começa com o nome", a primeira campanha com o objetivo de construção de marca produzida e veiculada no Brasil pela empresa. Após identificação dos temas e as figuras presentes no filme publicitário, depreendeu-se a narrativa global e os valores lá presentes, seguindo modelo aplicado por Pessôa (2013), e, associado à análise dos textos do site da Uber, deu-se, então, o reconhecimento dos componentes do projeto de marca, a enunciação fundamental, a promessa, a especificação da promessa, o território onde a marca está inscrita e os valores, de acordo com o modelo de Semprini (2010). Para que o projeto recomposto estivesse mais aderente à realidade da Uber, a estruturação foi levada à julgamento por um executivo da empresa que, por questões estratégicas e de confidencialidade, não pode ser identificado aqui. Após apresentação pela pesquisadora, o executivo avaliou e complementou o 
portfólio de produtos que havia sido descrito, eliminando aspectos que eventualmente estivessem fora do escopo pragmático de operação da empresa, de modo a obter um resultado que estivesse próximo ao que de fato é o projeto da marca Uber. Tal conduta seguiu o procedimento adotado por Pessôa, Sant'Ana e Mello (2015), ao estudar o caso da marca de acessórios Chili Beans.

O terceiro passo consistiu na análise da percepção dos consumidores entrevistados, através de seus discursos acerca das manifestações da marca Uber. Foram selecionadas três manifestações para a análise: Manifestação 1 Serviço Uber X; Manifestação 2 - Aplicativo; Manifestação 3 - Campanha publicitária "Confiança começa com o nome".

Para as manifestações 1 - Serviço Uber X e 2 - Aplicativo, foram colocadas questões durante o roteiro da entrevista, abordando especificamente aspectos específicos de tais manifestações. Finalizadas as perguntas do roteiro, foram apresentadas as peças publicitárias da campanha "Confiança começa com o nome", veiculada em 2018: o filme de 1:00' e um conjunto de quatro anúncios veiculados em redes sociais e mobiliário urbano, compondo assim a apresentação da Manifestação 3 - Campanha publicitária "Confiança começa com o nome".

Para cada manifestação, foi feita uma análise individual do que foi depreendido da percepção dos consumidores, como propõe Semprini (2010) e, em seguida, uma análise conjunta, dando origem à identidade manifesta, permitindo recompor o projeto manifesto, conforme esquematizado na Figura 5. A análise foi feita seguindo o percurso gerativo de sentido, considerando os valores, o nível profundo, a narração, o nível intermediário, narrativo, onde surge o sujeito e por fim, o nível dos discursos ou discursivo, o mais superficial. Os valores encontrados foram ainda submetidos à axiologia do consumo de Floch (1993).

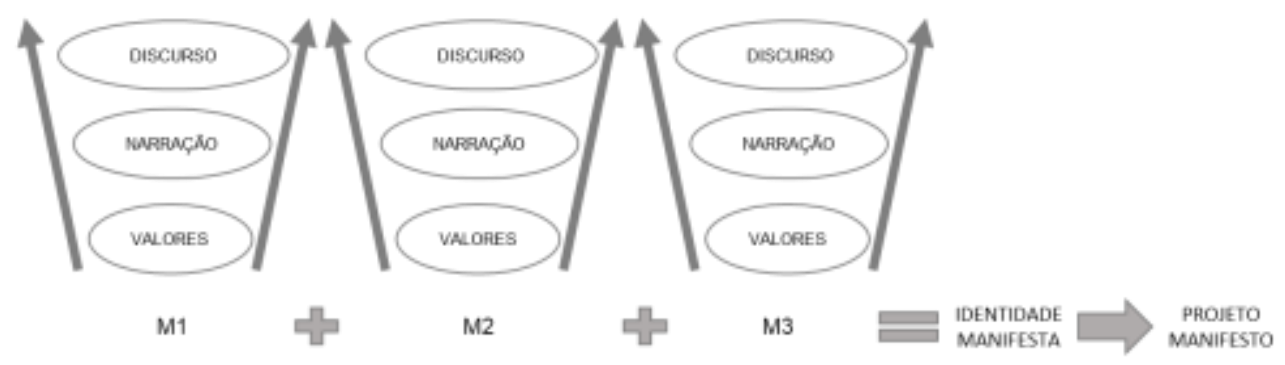

Figura 5: Identidade manifesta como somatório das manifestações da marca Fonte: adaptado de Semprini (2010, p. 160)

O último passo metodológico consistiu em comparar o projeto manifesto com o projeto de marca, identificando as aproximações e afastamentos entre eles e, em seguida, correlacionando-o com o contexto de consumo colaborativo, conforme Figura 1 apresentada no tópico 1.2. Objetivo. 


\section{3. \\ Composição do corpus de pesquisa}

A composição do corpus da pesquisa foi estruturada de acordo com a pergunta central e objetivos intermediários do estudo, sendo adequada à cada passo descrito anteriormente.

Para explorar os significados de consumo colaborativo, foi utilizado conteúdo gerado por meio de entrevistas individuais com consumidores brasileiros, tendo em vista suas experiências com as marcas Airbnb, Uber, OLX, eBay, apontadas pela literatura como marcas de consumo colaborativo.

Para a recomposição do projeto da marca Uber, foram utilizados o conteúdo do site oficial da empresa, anúncios publicitários veiculados no ano de 2018: peças de mobiliário urbano e filme publicitário veiculado na TV e na internet. As peças utilizadas encontram-se no Anexo 7.4.

Para análise das manifestações da marca Uber e aplicação do modelo de Semprini (2010) foi utilizado conteúdo gerado durante as entrevistas com os consumidores.

\subsection{1.}

\section{Realização das entrevistas}

Vergara (2009 p. 5) convenciona que as "entrevistas são úteis como um recurso em si mesmo ou como parte de um processo", o que se justifica aqui já que serão utilizadas também como complemento de pesquisa documental, quando os consumidores fazem observações sobre os anúncios e sobre trechos da comunicação no site da empresa.

Foi desenvolvido um formulário eletrônico com perguntas para préqualificação dos sujeitos para as entrevistas, conforme Anexo 7.1. O questionário foi publicado na página pessoal da pesquisadora no Facebook e distribuído em grupos de WhatsApp, recebendo respostas entre os dias 5 de outubro e 5 de novembro de 2018.

O convite era para responder a um questionário "cujo objetivo é investigar a utilização de serviços através de aplicativos tecnológicos entre consumidores brasileiros. " Optou-se por não revelar o tema do estudo, para tornar a seleção mais abrangente.

Foram recebidas 70 respostas ao questionário e todos os respondentes informaram serem ou terem sido usuários de aplicativos tecnológicos de transportes (Uber, 99, Cabify, TemBici, outros), conforme Figura 6 e, dentre eles, 
57 afirmaram haver utilizado um aplicativo de transportes na última semana (Figura 7).

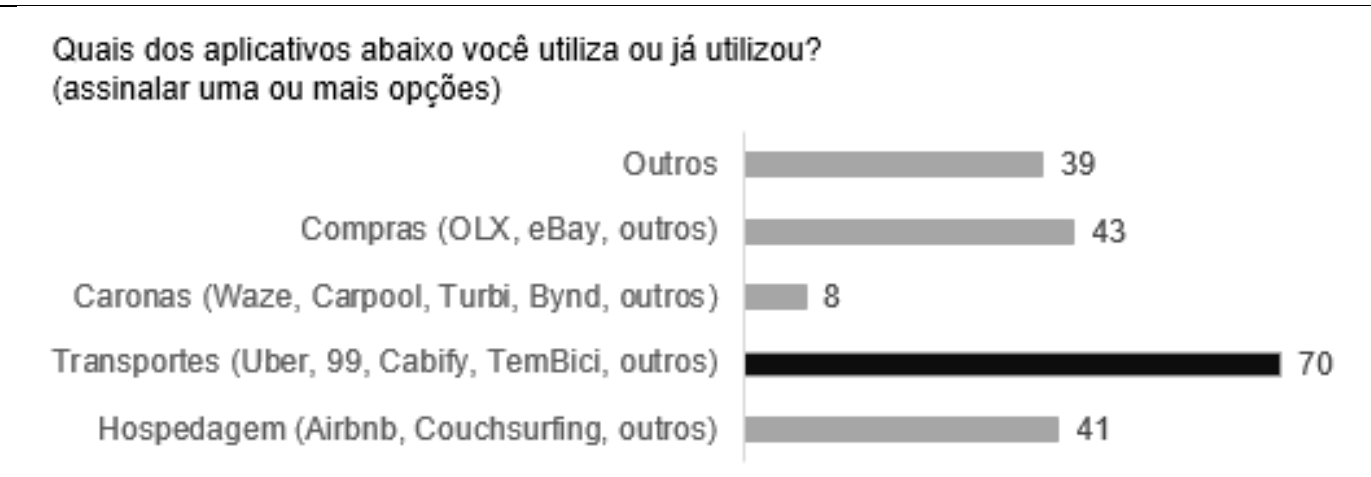

Figura 6: Identificação do tipo de aplicativo utilizado Fonte: Elaboração própria

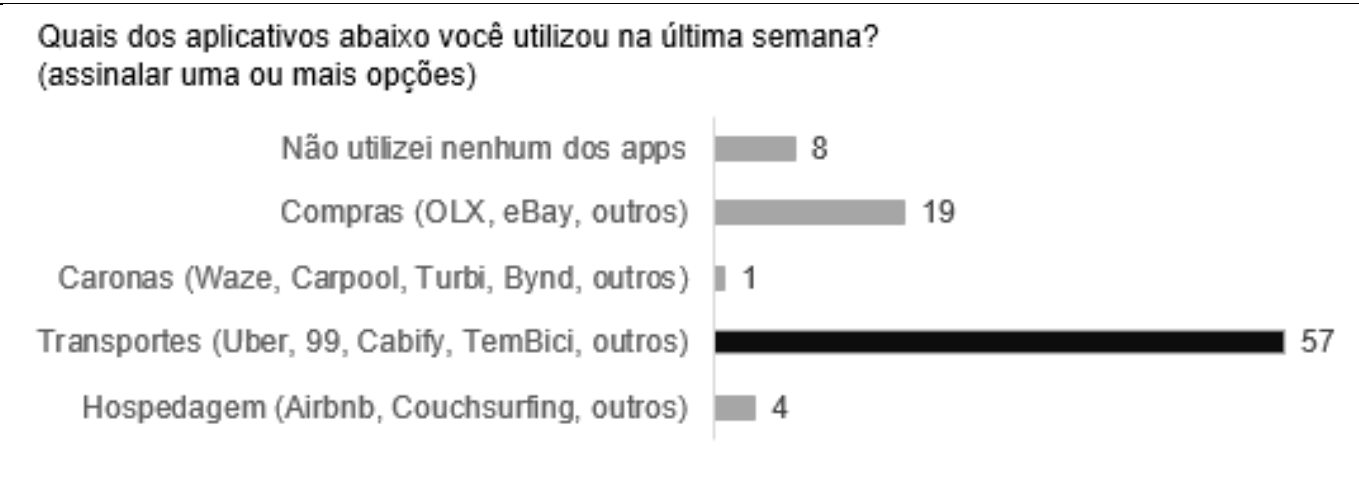

Figura 7: Identificação de utilização de aplicativos na última semana

Fonte: Elaboração própria

Entre os respondentes, trinta e dois prontificaram-se a participar de uma entrevista para investigar o uso de aplicativos e a seleção dos sujeitos que seriam convidados para a entrevista levou em consideração a utilização de pelo menos um aplicativo de transporte na última semana e que não possuíssem vínculos de proximidade com a entrevistadora.

Foram, então, enviados convites com a proposta de agendamento para vinte e oito pessoas. O envio foi feito por e-mail ou telefone, de acordo com a preferência indicada no questionário. Vinte e uma pessoas deram retorno, mas apenas quinze compareceram à entrevista. As entrevistas foram realizadas de forma presencial no período compreendido entre os meses de outubro de 2018 a janeiro de 2019. Foi escolhido um local de fácil acesso para o entrevistado, onde houvesse também aspectos positivos relacionados à segurança, bem como conforto térmico e acústico. Os entrevistados assinaram um termo de consentimento para que as entrevistas pudessem ser gravadas, conforme Anexo 7.3. 
Optou-se por um roteiro de estrutura semiaberta, para permitir inclusões, exclusões, mudanças nas perguntas e explicações ao entrevistado (Vergara, 2009). Foi elaborado um roteiro com as perguntas centrais, conforme Anexo 7.2 e, a partir dele, buscou-se encontrar evidências de práticas de consumo colaborativo, investigação sobre os serviços e aplicativos utilizados, disposição para se engajar em novas práticas, motivos para utilização do aplicativo Uber e suas impressões acerca das manifestações da marca a eles apresentadas. As peças de estímulo utilizadas nas entrevistas encontram-se no Anexo 7.4.

A Tabela 3 apresenta as características dos entrevistados. Os nomes foram modificados para preservar a identidade dos mesmos.

\begin{tabular}{|c|c|c|c|c|}
\hline Entrevistado & Idade & Formação & $\begin{array}{l}\text { Bairro de } \\
\text { residência }\end{array}$ & $\begin{array}{c}\text { Aplicativos } \\
\text { utilizados }\end{array}$ \\
\hline Joana & 22 & Ciências Sociais & Barra da Tijuca & Uber \\
\hline Miguel & 21 & Ciências Sociais & Recreio & Uber, Moovit, \\
\hline João & 42 & Publicidade & Laranjeiras & Uber, 99 \\
\hline Rebeca & 23 & Ciências Sociais & $\begin{array}{l}\text { Illha do } \\
\text { Governador }\end{array}$ & Uber, Moovit, 99 \\
\hline Lucas & 32 & Engenharia & Humaitá & EasyTaxi, 99, Uber \\
\hline Mateus & 28 & Economia & Recreio & iFood, Uber, 99 \\
\hline Luciana & 23 & Administração & Santa Tereza & $\begin{array}{l}\text { Uber, 99, Cabify, } \\
\text { Airbnb, BlaBlaCar }\end{array}$ \\
\hline Jonatan & 35 & Economia & Ipanema & Uber, 99, OLX \\
\hline Carina & 25 & $\begin{array}{l}\text { Relações } \\
\text { Internacionais }\end{array}$ & Copacabana & Cabify, Uber \\
\hline Hanna & 42 & Arquitetura & Alphaville-Manaus & Uber, 99 \\
\hline Raquel & 47 & Direito & Alphaville-Manaus & Uber, 99 \\
\hline Pompeu & 50 & Arquitetura & Barra da Tijuca & Uber, 99, eBay \\
\hline Camila & 35 & Administração & Copacabana & $\begin{array}{l}\text { 99, Uber, Cabify, } \\
\text { Airbnb }\end{array}$ \\
\hline Joaquim & 45 & $\begin{array}{l}\text { Comércio } \\
\text { Exterior }\end{array}$ & Copacabana & Uber, VA \\
\hline Clara & 47 & Fisioterapia & Jacarepaguá & Uber, Airbnb, 99 \\
\hline
\end{tabular}

Tabela 3: Perfil dos entrevistados

Fonte: Elaboração própria

A pesquisadora iniciou a entrevista agradecendo pela disponibilidade do entrevistado em participar e, de posse das informações preenchidas no questionário de qualificação, estabeleceu a abordagem com a afirmação "pela sua resposta ao questionário, observei que você utiliza um aplicativo de transporte, ou hospedagem, ou compras. Quais aplicativos você utiliza?"

A partir daí, seguiu-se o roteiro de perguntas, com algumas observações, ou ainda explorando pontos que poderiam trazer à luz informações relevantes para a análise. Foram observados cuidados para não interromper os depoimentos dos entrevistados, nem fazer nenhum tipo de julgamento sobre o que estava sendo falado. 
Em seguida, foram utilizados recursos audiovisuais, sobre os quais os entrevistados deveriam discorrer. A ordem apresentada foi: logo e peças publicitárias da marca Airbnb, logo e peças publicitárias da marca Uber, incluindo o filme publicitário da campanha "Confiança começa com o nome" (Anexo 7.4). Foi exibido também um slide contendo alguns trechos da página oficial da empresa, seção Fatos e dados sobre a Uber, conforme abaixo:

A Uber é uma empresa de tecnologia que está transformando a maneira como pessoas se movimentam. Ela conecta usuários e motoristas parceiros por meio de seu app.

\section{O que não fazemos}

$\checkmark$ A Uber não é uma empresa de transporte. A Uber é uma empresa de tecnologia. Nós desenvolvemos um aplicativo que conecta motoristas parceiros a usuários que desejam se movimentar pelas cidades.

$\checkmark$ A Uber não é um aplicativo de táxi. Nós conectamos usuários e motoristas parceiros, que prestam o serviço de transporte individual privado, por meio de nosso aplicativo.

$\checkmark \quad$ A Uber não é um serviço de carona paga ou remunerada. A Uber é uma empresa de tecnologia que possibilita, por meio de seu aplicativo, que motoristas parceiros encontrem pessoas que precisam de viagens acessíveis e confiáveis. O usuário chama um motorista parceiro, que o leva para o destino que ele deseja.

$\checkmark$ A Uber não emprega nenhum motorista e não é dona de nenhum carro. Nós oferecemos uma plataforma tecnológica para que motoristas parceiros aumentem seus rendimentos e para que usuários encontrem motoristas confiáveis e desfrutem de viagens confortáveis (UBER, 2018).

Por fim, dois conceitos de consumo colaborativo foram expostos aos entrevistados:

Consumo colaborativo é formado por pessoas coordenando a aquisição e distribuição de um recurso por um valor ou outra compensação. Por outra compensação, a definição também abrange permuta, negociação e troca, envolvendo a concessão e recebimento de compensações não monetárias. E exclui atividades de compartilhamento que não possuem compensação envolvida e o ato de presentear, onde há a transferência permanente de propriedade (BELK, 2014, p. 1597).

O compartilhamento forma comunidades, promove a economia de recursos e cria sinergias, definindo o que é "nosso", mais do que o que é "meu" ou "seu". Podem ser compartilhados não apenas os bens, mas também animais, ideias, valores, tempo. (BELK, 2007, p. 611).

As entrevistas tiveram duração entre trinta e cinquenta minutos. Ao final, a pesquisadora agradeceu novamente a contribuição e pediu permissão para novo contato, caso fosse necessário ratificar alguma informação.

Todas as entrevistas foram gravadas e posteriormente transcritas para facilitar a análise dos dados. 


\section{4.}

\section{Limitações do método}

Por ser de natureza qualitativo-interpretativa, o presente estudo apresenta algumas limitações. A primeira diz respeito à técnica escolhida para coleta dos dados, as entrevistas. Vergara (2009) postula que uma das limitações das entrevistas, diz respeito ao tempo a ela dedicado por parte do entrevistado. Alguns entrevistados dispunham de pouco tempo, o que pode ter limitado suas respostas. A outra limitação diz respeito à finalidade dos resultados. A pesquisa qualitativa não prevê resultados conclusivos nem generalizações (MALHOTRA, 2004). 


\section{4}

\section{Análise e interpretação dos dados}

A análise dos dados se iniciou a partir das transcrições das entrevistas, foi complementada com a análise do material sobre a marca Uber e será apresentada em duas etapas. A primeira dedica-se a explicitar o entendimento dos entrevistados sobre consumo colaborativo e a segunda é dedicada à marca Uber.

Os achados sobre consumo colaborativo serão agrupados em temas, da forma que Bardin (1977) recomenda, visando descobrir os núcleos de sentido que compõem os discursos dos entrevistados.

Serão apresentadas as informações levantadas sobre a marca Uber e, em seguida, serão expostas as percepções dos entrevistados acerca da marca, sua inserção no contexto de consumo colaborativo, os motivos para se engajar na plataforma e os sentimentos em relação às suas experiências com a marca.

$\mathrm{Na}$ sequência, será feita a aplicação do modelo Projeto/Manifestação de marca (SEMPRINI, 2010), em três fases: Inicia-se com a recomposição do projeto da Uber, realizada através do conteúdo do site da empresa e do filme publicitário da campanha "Confiança começa com o nome" e, em seguida, será encontrado o projeto manifesto através dos discursos dos entrevistados acerca das manifestações da marca Uber, organizados de acordo com o modelo Projeto/manifestação de marca (SEMPRINI, 2010) e da axiologia do consumo de Floch (1993).

Por fim, será realizada a verificação das aproximações e afastamentos entre o projeto de marca e o projeto manifesto da marca Uber, no contexto de consumo colaborativo.

\section{1.}

\section{Consumo colaborativo}

Assim como na literatura pesquisada, não há consenso sobre o conceito de consumo colaborativo entre os consumidores pesquisados. Os entrevistados foram questionados sobre o conceito e sobre suas práticas de consumo colaborativo. Seguindo o processo recomendado por Bardin (1977) foi utilizada a categorização para agrupar os dados encontrados, utilizando o critério semântico 
para classificá-las, dando origem a categorias temáticas. Os dados foram agrupados em três categorias:

\section{$\checkmark$ Conceito de consumo colaborativo \\ $\checkmark$ Práticas de consumo colaborativo \\ $\checkmark$ Disposição para o consumo colaborativo}

\subsection{1.}

\section{Conceito de consumo colaborativo}

A primeira categorização diz respeito ao conceito de consumo colaborativo. Ao serem questionados sobre seu entendimento acerca do conceito, poucos entrevistados tinham exemplos claros da prática. Alguns exemplos foram expressos:

Eu participei durante um tempo de uma rede de consumo colaborativo de orgânicos e eles traziam do produtor para um centro de distribuição e a gente era convidado a participar da distribuição, a gente fazia a alocação não só do nosso próprio consumo, mas a alocação dos outros também e com isso todos nós pagávamos menos taxas porque a gente entrava com uma parte do nosso salário (...) éramos pessoas coordenando aquisição e distribuição de recursos. (Lucas)

Tal exemplo alinha-se ao que Belk (2007) teoriza sobre compartilhamento, promovendo economia de recursos e sinergias e também ao conceito de consumo colaborativo de Vaquero e Calle (2013), pois sugere promover a cooperação entre as pessoas, despertar um senso de comunidade e reforçar o sentimento de compromisso.

O outro exemplo trazido por Lucas não encontra respaldo no protótipo de compartilhamento de Belk (2007), já que é uma troca, há compensação financeira, tornando-se um processo de compra e venda. Tal depoimento, no entanto, encontra sinergia na definição de Botsman e Rogers (2010) e é complementado pelo relato de Camila, que tem o mesmo entendimento:

Eu vejo isso acontecendo muito mais no momento que a gente vai pra uma feira de artesanato, de produtos artesanais, no momento que a gente vê aqui pessoas vendendo a comida que fazem em casa, como uma forma de complementar a renda. (Lucas)

Eu até prefiro pensar em consumo colaborativo como se fosse essa questão monetária mesmo. Esse negócio de você ter que fazer um favor pra alguém em troca de... eu prefiro assim, ter o serviço... ah a pessoa tem o carro me faz uma viagem do ponto $\mathrm{A}$ ao ponto $\mathrm{B}$, eu prefiro pagar do que ficar devendo a ela, (...) eu prefiro pensar consumo colaborativo sim, envolve essa questão monetária. (Camila) 
O depoimento de Mateus destaca que não deve haver compensação financeira nas práticas de consumo colaborativo:

No caso do consumo colaborativo eu colocaria, por exemplo, as caronas que tinham aqui na PUC, o efeito de carona de maneira geral, a pessoa não ganha nada com isso, tá dando só carona(...) pra mim, colaborativo é um ajudar o outro e essa corrente vai se estendendo. (Mateus)

Embora trate de cooperação quando cita "um ajudar o outro", adequando-se ao conceito de Vaquero e Calle (2013), há um ponto de divergência relacionado à compensação quando o entrevistado afirma que "não ganha nada com isso", alinhando-se à definição de Felson e Spaeth (1978). Tal entendimento também pode se encaixar na definição de Albinsson e Perera (2012). Por sua vez, os depoimentos de Jonatan e Pompeu também divergem no que tange à compensação, encaixando-se na forma mais abrangente conceituada por Botsman e Rogers (2010):

A casa para mim é um exemplo de consumo colaborativo. Eu já botei amigo pra morar lá em casa seis meses, porque ele morava em Niterói e trabalhava na Barra, e eu morava na Barra com a minha mãe. (Jonatan)

É você utilizar recursos que você já tenha ou bens que você já tenha, compartilhar com alguém, ceder o uso, fornecer o uso, sem a compensação financeira. (Pompeu)

Raquel usa o termo acesso, aproximando seu entendimento ao de Bardhi e Eckhardt (2012):

Consumo colaborativo é uma experiência de consumo onde as pessoas, em vez de as pessoas tão somente pagarem por um produto ou serviço, compartilham, e dessa forma, multiplicam a possibilidade de uso e o acesso ao serviço ou produto. (Raquel)

O depoimento de João sugere ser o mais alinhado ao conceito de Belk (2010), já que trata da troca de um recurso por uma compensação:

Pessoas que trocam um recurso que tá sobrando, por alguma remuneração ou algo do tipo. (João)

\subsection{2.}

\section{Práticas de consumo colaborativo}

A segunda categoria diz respeito às práticas de consumo colaborativo. Ao serem questionados sobre suas práticas, alguns entrevistados usaram também variações do verbo compartilhar para descrevê-las, sugerindo um entendimento de que os termos seriam sinônimos. 
A minha mãe tem um carro, a minha irmã não tem. Aí vira e mexe, "ah tô indo aí pegar o carro" ah beleza, ou tipo roupa com a minha irmã, ah eu preciso de uma roupa assim e tal, vou aí pegar na sua casa, eu calço a mesma coisa que a minha irmã, eu visto a mesma coisa que a minha irmã, então tipo, essa economia compartilhada na minha família é o tempo todo. (Camila)

Eu costumo compartilhar o notebook da minha filha. Ela está estudando e geralmente é ela quem usa, mas quando preciso, uso também. Ela reclama um pouco, mas cede. (Clara)

Eu uso o carro compartilhado com o meu pai. É um pouco ruim. Às vezes, nos finais de semana meu pai vai para a casa da namorada com o carro dele, fica meio ruim porque eu quero fazer alguma coisa e não posso porque estou sem carro. Aí eu pego Uber ou transporte público. (Joana)

Da forma que as variações do termo compartilhamento foram utilizadas por Camila, Clara e Joana, a prática sugere estar alinhada que Belk (2007 p. 126) define como "o ato de receber ou tomar algo de outros para nosso próprio uso".

Em outro depoimento, Joana descreve práticas que destacam o papel facilitador da tecnologia para o consumo colaborativo (JOHN, 2012; PISCICELLI; COOPER; FISHER, 2015). Miguel e Mateus complementam, descrevendo práticas semelhantes:

Eu tô usando o Spotify e recentemente pedi pra minha amiga compartilhar a lista dela de músicas comigo, pra eu baixar algumas músicas. Tenho também grupos no Whatsapp e Instagram com amigos, onde a gente compartilha notícias e coisas engraçadas. (Joana)

Eu uso o Spotify na conta família com minha mãe e minha irmã (...) mas não compartilho músicas com elas porque têm gostos diferentes (...) uso Netflix com meus amigos compartilhado. (Miguel)

Compartilho artigos publicados mesmo porque tá lá na rede e qualquer um pode mexer de graça, a maioria deles é de graça, qualquer um pode pegar e compartilhar sem problema nenhum. (Mateus)

O depoimento de Jonatan pode ser considerado uma prática de compartilhamento aberto (BELK, 2010) sem a mediação da tecnologia (JOHN, 2012) para a prática de compartilhamento por ele citada.

Eu abro a minha casa pra amigos meus do mundo inteiro né... mas não cobrando. Semana que vem está chegando uma amiga minha russa (...) eu já botei amigo para morar lá em casa seis meses. (Jonatan)

Já o depoimento de Luciana refere-se ao mesmo tipo de serviço, de hospedagem que, em seu caso, tornou-se um negócio, quando decidiu alugar quartos da sua casa através da plataforma tecnológica Airbnb: 
Quando eu fui pra Espanha em 2013, a pessoa que alugava o quarto pra mim, ela tinha vários imóveis e ela vivia disso, ela vivia alugando quartos e casas no Airbnb e em outros lugares. Quando eu voltei pro Brasil, meu pai estava se mudando, a gente foi pra uma casa vazia e eu falei: "pô, vamos fazer" aí a gente montou os quartos, eram seis quartos, e a gente começou a usar o Airbnb para oferecer os serviços. (Luciana)

Outro trecho da entrevista de Luciana pode encontrar uma alusão ao que Belk (2010) denominou de compartilhamento para fora, que se dá entre estranhos:

\begin{abstract}
Minha mãe começou a alugar um dos quartos de casa no Airbnb... o quarto que sobrava lá em casa, tipo pra carnaval e ano novo (...) que a gente conseguia ganhar um bom dinheiro, ela estava precisando e era uma semana no máximo, ela saia de casa as vezes, tipo ia pra casa da minha avó quando ela estava meio incomodada, porque bem ou mal é alguém na sua casa né... se você mora lá... então você tem que relevar um pouco. (Luciana)
\end{abstract}

Outra prática citada por Luciana, que também pode ser descrita como compartilhamento para fora é a de caronas através do aplicativo BlaBlaCar.

Eu estava indo pra Friburgo, na verdade estava indo pra São Pedro da Serra, e aí a gente ia passar por Friburgo na ida, a gente ia pelo outro lado, e aí você pode oferecer a carona pra deixar a pessoa pelo caminho, mas todo mundo ia ficar em Friburgo, a gente deixou todo mundo lá. E a pessoa paga em dinheiro pra você no carro, isso é bem estranho, mas aconteceu e foi tranquilo. (Luciana)

Ao utilizar os termos "meio incomodada" na experiência do Airbnb e "bem estranho" na experiência do BlaBlaCar, a entrevistada Luciana sugere não estar à vontade para compartilhar com estranhos, encontrando respaldo na afirmação de Belk (2010), de que o compartilhamento é menos frequente entre estranhos.

Os depoimentos de Mateus e João respondem o questionamento feito por Belk (2014 p. 1598): "por que possuir quando você pode alugar por hora?", destacando a vantagem do acesso em relação à posse, encaixando-se também no que Bardhi e Eckhardt (2012) denominaram de consumo baseado no acesso:

Tenho o aplicativo Itaú Bike Rio. Na verdade, eu moro próximo a praia e de vez em quando uso lá... (...) pra dar uma volta na ciclovia, mais pela área ali...(...) Só pego bicicleta de lá, até porque não uso muito então é mais pra final de semana ou pra dar uma voltinha, até porque o quarto lá de bagunça não dá espaço pra duas bicicletas, então isso daí é que me leva a pegar isso daí lá. (Mateus)

Já usei a bicicleta do Itaú, e foi interessante, usei na época que era novidade, para experimentar, para conhecer, (...) aí comecei a ter uma vida em que a bicicleta não se encaixava mais, eu abandonei. Mas cheguei a usar, gostei, não precisei comprar a bicicleta (João).

As entrevistadas Hanna e Rebeca descrevem experiências onde a prática de compartilhamento foi aprendida socialmente, na família, da forma como foi observado no estudo de Levy (2015) e que pode ser descrito como compartilhamento para dentro segundo Belk (2010). 
Quando era criança, compartilhava tudo, apesar de ser filha única, tudo, minha mãe sempre educou isso, de partilhar, de compartilhar com as primas, com as amigas, brinquedos, lanchinhos, experiências, formas de ver e perceber as coisas. (Hanna)

Já compartilhei o computador com a irmã, quando era mais nova e era chato, era ruim, porque minha mãe estipulava horário e era meio chato. (Rebeca)

As experiências de Hanna e Rebeca também se adequam ao que foi proposto por Botsman e Rogers (2010): aprende-se a compartilhar ainda na infância, quando os pais estimulam que a criança compartilhe seus brinquedos com amigos ou irmãos. Outros exemplos de compartilhamento para dentro, na família e com pessoas próximas, foram os citados por Carina.

A gente compartilha computador, a gente compartilha televisão, as coisas básicas. (Carina)

Quando eu viajo compartilho quartos, por exemplo, com meu namorado, (...) quando eu saio com meus colegas, por exemplo, no almoço, a gente compartilha comida. (Carina)

O entrevistado Lucas sugere ser orientado à não propriedade e utiliza os serviços de transporte público ou através de aplicativos para suprir suas necessidades de transporte depois que decidiu não ter carro (LINDBLOM; LINDBLOM, 2017).

Há alguns anos eu tomei a decisão de não ter carro (...) meu traslado é sempre curto, curta distância (...) A partir do momento que lançaram o primeiro aplicativo eu já estava embarcado nele. (Lucas)

Uma das entrevistadas demonstrou saudosismo ao se referir às experiências como anfitriã no Airbnb, destacando valores sociais que, segundo ela, no início da prática, eram evidentes.

Quando a gente começou a receber gente, era uma coisa, assim, muito mais íntima, as pessoas traziam presentes, te agradeciam, parecia que estava recebendo alguém em casa... tipo eu me sentia bem de conversar com a pessoa saber da vida dela e tal... eu adorava $O$ tempo passou (...) muita gente na cidade toda, começou a alugar também, (...) e as pessoas vinham tipo esperando que iam ficar num Hotel, que ia ter alguém ali pra te receber, que iam ficar ali, não queriam conversar, é o que eu sinto... tipo, você estava ali oferecendo um negócio, era isso e acabou. Eu não sinto mais essa relação próxima assim que tinha anteriormente. (Luciana)

\subsection{3.}

\section{Disposição para o consumo colaborativo}

Ao serem questionados se teriam disposição para praticar o consumo colaborativo e de que forma, os entrevistados trouxeram depoimentos que 
encontram respaldo na literatura estudada. O depoimento de Jonatan se encaixa no motivo social descrito por Benoit et al. (2017):

Teria disposição para abrir a casa como um espaço compartilhado para receber alguém (um estranho) não uma coisa contínua, mas assim, teria, teria, num feriado, numa coisa assim teria, porque eu morei fora, então eu gosto dessa troca. (Jonatan)

O depoimento de Mateus ilustra o que Albinsson e Perera (2012) denominaram de consumo alternativo, atividades de colaboração que não envolvem a troca monetária:

Uma coisa que eu acho muito legal, mas não foi muito pra frente lá no meu bairro foi biblioteca comunitária colaborativa, você levava livros pra lá e trocava livros, enfim, meio que doava livros e pegava outros livros pra ler, aquela biblioteca móvel, enfim, durou um pouco de tempo no Recreio e depois acabou. (Mateus)

Ao ser questionado se utilizaria um serviço de compartilhamento de carros se houvesse em sua cidade, o entrevistado Mateus se mostrou favorável, destacando a redução de riscos e responsabilidades (Benoit et al., 2017) como motivo para se engajar:

Se tivessem carros disponíveis... se eu peguei um carro pra gávea e tenho certeza que esse carro vai estar disponível pra eu voltar, eu não me incomodaria de pegar (...) então se eu tenho certeza que aquele carro vai estar disponível pra mim, no horário que eu preciso pra voltar... show. (Mateus)

João utiliza a palavra acesso, alinhando-se à proposta de Bardhi e Eckhardt (2012) e sugere um aproveitamento de recursos (PISCICELLI; COOPER; FISCHER, 2015):

\begin{abstract}
Algumas coisas eu gostaria de usar porque tem coisas que eu sei que são recursos mal aproveitados, que eu tenho acesso. Ou coisas que eu precisava ter acesso e não tenho, como se fosse uma biblioteca de coisas que você precise. Eu uso uma batedeira de vez em nunca, por que não tem uma batedeira para cada dez vizinhos, seria muito mais racional. (João)
\end{abstract}

Os entrevistados Joaquim, Clara, Camila e Pompeu ressaltam aspectos negativos para algumas práticas de compartilhamento, sugerindo baixa disposição para compartilhar.

Já usei a bicicleta Bike Rio e não gostei. Acho que bicicleta é algo muito pessoal, tem a questão da higiene. No Canadá, as bicicletas têm forros para os assentos. Aqui no Brasil, além de não ter isso, as pessoas não tomam cuidado. Como sabem que não é algo que lhes pertence, não se preocupam em cuidar. (Joaquim)

Quanto aos serviços compartilhados, eu não utilizaria, pois não gosto da ideia de viajar com estranhos. Jamais dormiria num albergue em quarto coletivo. Além da invasão de privacidade e até o risco de discussões acaloradas na viagem, no Brasil 
o risco de um dos passageiros ter um perfil falso no Uber e assaltar os demais é grande. E não gosto de compartilhar ou emprestar meus pertences. (Joaquim)

Eu não gosto de usar o Uber Pool, porque pode entrar uma pessoa estranha, ou mudar meu trajeto, posso me atrasar. (Clara)

Eu acho quando você compartilha alugando quarto na casa de alguém você não consegue manter seu espaço pessoal (...) na última viagem eu peguei um albergue na Espanha, tinha quatro camas, eu dividi com a minha amiga então fomos só nos duas e tiveram outras pessoas no quarto... é chato, é chato, eu não gosto não, mas foi assim, na Espanha estava tudo muito caro. (Camila)

Não uso o Uber Juntos pelo fator segurança, principalmente, e você nunca sabe, se você tem um compromisso e escolher o Uber Juntos, se você consegue chegar nesse compromisso, se você não vai se desviar muito do caminho original. (Pompeu)

Pompeu, que afirma já ter compartilhado quando criança, hoje alega não possuir essa disposição:

Hoje acho que não seria interessante, talvez na época de criança e adolescente, você não tivesse tantas ressalvas, e não pensasse tanto, talvez isso fizesse com que você tivesse esse costume mais naturalmente. Mas hoje não me sinto à vontade. (Pompeu)

Observa-se nos relatos que uma barreira para a adoção do consumo colaborativo é a segurança. Mesmo quem o pratica, sugere não estar confortável, em alguns relatos sobre suas práticas, como a entrevistada Luciana que usou palavras como "estranho" e "incomodada". No caso dessa entrevistada, tal desconforto parece ser específico a situações no Brasil, já que ela alega adotar as práticas em suas viagens para outros países.

Ao analisar a idade dos entrevistados que apontaram aspectos negativos, observa-se que três deles, possuem idade a partir de 45 anos, sugerindo que as gerações mais velhas não apresentam inclinação à não propriedade, o que reduz a sua disposição para compartilhar, alinhando-se aos achados de Lindblom e Lindblom (2017).

\section{2.}

\section{A Uber}

Fundada em 2009, em São Francisco, na Califórnia, pelos empreendedores digitais Travis Kalanick e Garret Camp, a Uber nasceu com o propósito de ser um serviço de alto valor percebido, que facilitaria a mobilidade urbana nas grandes cidades, conectando usuários a motoristas particulares de carros de luxo, através de um aplicativo para dispositivos móveis. Pressionada pela necssidade de escalar o negócio e pela concorrência das empresas de ridesharing ou viagens 
compartilhadas, que ofereciam preços inferiores, identificou a oportunidade de popularizar o serviço e gerar oportunidades de emprego e renda, criando as variações, Uber X, Uber Pool e Uber Select, nas quais poderiam se cadastrar proprietários de qualquer tipo de carro, facilitando a expansão para outras cidades e países (SLEE, 2017), Uber Pool, de viagens compartilhadas e Uber Select.

Em meio a controvérsias, conflitos com os provedores de serviços tradicionais, como o taxi, questões regulamentares com prefeituras das cidades onde atua e crises de confiança entre os usuários, a empresa cresceu e hoje, em sua página oficial na internet, afirma atuar em mais de seiscentas cidades, de sessenta e cinco países, efetivando em média, quinze milhões de viagens por dia, atendendo a mais de setenta e cinco milhões de usuários e reunindo mais de três milhões de motoristas parceiros. A marca se apresenta da seguinte forma:

"Quem somos: Criamos oportunidades ao colocar o mundo em movimento: Quando as pessoas têm mobilidade, tudo é possível. As oportunidades surgem, as portas se abrem e os sonhos se tornam realidade. A tecnologia que começou como uma forma de pedir uma viagem com o toque de um botão já possibilitou bilhões de conexões entre pessoas no mundo todo" (UBER, 2018).

No Brasil, a empresa informa estar presente em mais de cem cidades, conectando mais de quinhentos mil motoristas parceiros a mais de vinte milhões de usuários. São Paulo é a cidade com o maior número de viagens no mundo, seguida pelo Rio de Janeiro. O portfólio brasileiro é composto por nove produtos principais que podem ser adaptados a diferentes cidades (Tabela 4).

Em algumas cidades dos Estados Unidos há ainda os serviços de bicicletas elétricas (Jump) e patinetes elétricos. Há também o Uber Freight, dedicado ao transporte de cargas e Uber Health, que conecta pacientes a provedores de serviços de saúde, oferecendo transporte para consultas médicas e exames. Em outros países, a empresa possui modalidades distintas de ridesharing, como o Uber Tuk Tuk, na Índia, e o Uber XL, em Londres, oferecendo veículos com capacidade para seis ou mais passageiros. Além disso, a empresa pretende lançar a modalidade Uber Air, transporte urbano aéreo e realiza testes de serviços utilizando veículos semiautônomos.

Embora tenha enfrentado prejuízos milionários em 2017, perdendo cerca de US\$ 20 bilhões em seu valor de mercado, o novo CEO da empresa, Dara Khosrowshahi, atua num programa de mudança de cultura e operações, atraindo novos investidores para a marca, com planos de abrir o capital em 2019.

É considerada a empresa de tecnologia mais valiosa do mundo, conforme artigo publicado no site Business Insider, em maio de 2018. Outro artigo, publicado em outubro de 2018 pelo Wall Street Journal, anuncia que a empresa recebeu 
ofertas propostas de bancos de Wall Street, avaliadas em US $\$ 120$ bilhões, valor que representa mais que o dobro do apresentado na avaliação recebida dois meses antes, e superior à soma dos valores das empresas General Motors Co., Ford Motor Co. e Fiat Chrysler Automobiles.

\begin{tabular}{|c|c|c|c|}
\hline Serviço & Categoria & Apresentação & Característica \\
\hline Uber X & $\begin{array}{l}\text { Ridesharing } \\
\text { Transporte de } \\
\text { passageiros }\end{array}$ & $\begin{array}{l}\text { Ideal para sua } \\
\text { locomoção } \\
\text { cotidiana }\end{array}$ & $\begin{array}{l}\text { Carros compactos, } \\
\text { com ar } \\
\text { condicionado e } \\
\text { quatro portas }\end{array}$ \\
\hline $\begin{array}{l}\text { Uber X VIP } \\
\text { Variação do Uber X } \\
\text { para passageiros } \\
\text { frequentes, } \\
\text { disponível em } \\
\text { algumas cidades. }\end{array}$ & $\begin{array}{l}\text { Ridesharing } \\
\text { Transporte de } \\
\text { passageiros }\end{array}$ & $\begin{array}{l}\text { Vantagens para os } \\
\text { usuários mais } \\
\text { frequentes }\end{array}$ & $\begin{array}{l}\text { Modalidade que } \\
\text { conecta os usuários } \\
\text { que mais viajam } \\
\text { com os motoristas } \\
\text { parceiros mais bem } \\
\text { avaliados na } \\
\text { plataforma }\end{array}$ \\
\hline Uber Select & $\begin{array}{l}\text { Ridesharing } \\
\text { Transporte de } \\
\text { passageiros }\end{array}$ & $\begin{array}{l}\text { Mais conforto, sem } \\
\text { pesar no bolso }\end{array}$ & $\begin{array}{l}\text { Carros } \\
\text { selecionados, mais } \\
\text { confortáveis e } \\
\text { espaçosos, com } \\
\text { bancos de couro e } \\
\text { ar condicionado }\end{array}$ \\
\hline Uber Juntos & $\begin{array}{l}\text { Ridesharing } \\
\text { Transporte de } \\
\text { passageiros }\end{array}$ & $\begin{array}{l}\text { Compartilhando } \\
\text { viagens e } \\
\text { economizando }\end{array}$ & $\begin{array}{l}\text { Carros compactos, } \\
\text { com ar } \\
\text { condicionado e } \\
\text { quatro portas }\end{array}$ \\
\hline Uber Black & $\begin{array}{l}\text { Ridesharing } \\
\text { Transporte de } \\
\text { passageiros }\end{array}$ & $\begin{array}{l}\text { Viagens exclusivas } \\
\text { em veículos de alto } \\
\text { nível }\end{array}$ & $\begin{array}{l}\text { Carros pretos de } \\
\text { luxo, motoristas } \\
\text { profissionais }\end{array}$ \\
\hline $\begin{array}{l}\text { Uber Bag } \\
\text { apenas na cidade } \\
\text { de em São Paulo }\end{array}$ & $\begin{array}{l}\text { Ridesharing } \\
\text { Transporte de } \\
\text { passageiros }\end{array}$ & $\begin{array}{l}\text { Mais espaço para } \\
\text { suas malas ou } \\
\text { pertences }\end{array}$ & $\begin{array}{l}\text { Carros que } \\
\text { usualmente operam } \\
\text { no Uber X ou Uber } \\
\text { Juntos, com porta } \\
\text { malas maior, para } \\
\text { transporte de } \\
\text { bagagens }\end{array}$ \\
\hline $\begin{array}{l}\text { Uber Bag Black } \\
\text { apenas na cidade } \\
\text { de em São Paulo }\end{array}$ & $\begin{array}{l}\text { Ridesharing } \\
\text { Transporte de } \\
\text { passageiros }\end{array}$ & $\begin{array}{l}\text { Mais espaço para } \\
\text { suas malas ou } \\
\text { pertences }\end{array}$ & $\begin{array}{l}\text { Carros que } \\
\text { usualmente operam } \\
\text { no Uber Black com } \\
\text { espaço dedicado } \\
\text { para o transporte de } \\
\text { bagagens. }\end{array}$ \\
\hline $\begin{array}{l}\text { Uber para } \\
\text { Empresas }\end{array}$ & $\begin{array}{l}\text { Ridesharing } \\
\text { Transporte de } \\
\text { passageiros }\end{array}$ & $\begin{array}{l}\text { Transporte } \\
\text { descomplicado para } \\
\text { a sua empresa }\end{array}$ & Indiferente \\
\hline Uber Eats & Comida & $\begin{array}{l}\text { Levando seus } \\
\text { pratos favoritos até } \\
\text { você }\end{array}$ & $\begin{array}{l}\text { Veículos para } \\
\text { delivery }\end{array}$ \\
\hline
\end{tabular}

Tabela 4: Tipos de Serviço oferecidos no Brasil pela Uber

Fonte: Elaboração própria. Adaptado de: www.uber.com/about 


\subsection{1.}

\section{Uber no contexto do consumo colaborativo}

Os entrevistados foram questionados se, ao utilizarem o serviço prestado pela Uber, estariam inseridos numa prática de consumo colaborativo ou compartilhamento e as opiniões foram divergentes. Os depoimentos de João e Joaquim se adequam ao que foi proposto por Belk (2007, 2010):

Acredito que quando uso Uber, estou recebendo algo que é de outro, o carro que é do motorista, para o meu uso. (João)

Eu acho que é sim. O mesmo carro está sendo usado por várias pessoas. Todas essas pessoas que usam, estão deixando de usar um carro a mais, o que é bom pro meio ambiente. O carro está sendo usado durante todo tempo, ele não fica parado. (Joaquim)

Joaquim, contudo, afasta-se do conceito quando se refere à compensação monetária e alinha-se ao entendimento de Miguel.

E o motorista ainda consegue ganhar uma renda extra ou mesmo, tirar o seu sustento dali. (Joaquim)

Considero o Uber uma atividade de compartilhamento porque acho que ele compartilhar o veículo dele pra atribuir renda, uma renda a mais, para as contas do final do mês, acho que sim (Miguel).

Tais relatos encontram respaldo no conceito de consumo colaborativo de Botsman e Rogers (2010), que prevê compensação monetária na modalidade.

O depoimento de Luciana está em linha com a definição de consumo baseado no acesso defendida por BARDHI e ECKHARDT (2012), onde não há a transferência de propriedade e nem o sentimento de propriedade do bem.

Eu acho que o Uber é consumo colaborativo sim, mas não me sinto fazendo parte de uma comunidade e nem sinto que o carro é meu. (...) às vezes o carro não é nem da pessoa que está dirigindo, as vezes eles alugam o carro, não sei se eles sentem que é nosso ou deles, ou só deles não sei. (Luciana)

Em oposição, os entrevistados que não se sentem compartilhando ao usar Uber, justificam suas respostas. Os depoimentos de Joana, Jonatan, Mateus e Rebeca e Raquel estariam alinhados ao que Belk (2010) definiu como troca de bens, que é diferente do compartilhamento ou do consumo colaborativo, uma vez que há compensação financeira, o pagamento pelo uso do serviço:

Não me sinto compartilhando ao usar o Uber porque eu tô indo pra um lugar, sou só eu que estou indo praquele lugar, tô pagando e não me sinto compartilhando nada. Me sinto compartilhando só o ambiente que é o carro, mas estou pagando por isso (Joana). 
Não sinto que estou compartilhando ao usar o Uber, estou consumindo, não...estou comprando (Jonatan).

Eu não acho que Uber seja considerado compartilhamento, porque existe compensação envolvida (...) não sinto que estou compartilhando com aquele motorista que é dono daquele carro, eu acho que está prestando um serviço só, tá recebendo por isso. (Mateus)

Não sinto que estou compartilhando quando uso o Uber, não sinto como se o carro fosse meu. Uso como um táxi mesmo, não me sinto compartilhando, não tenho esse sentimento. (Rebeca)

Não. Inclusive eles dizem que não são serviço de carona remunerada. (Lucas)

Pra mim é um serviço, que estou comprando, pagando por ele. (Pompeu)

Como que pode ser consumo colaborativo se quem não tem um carro, aluga um carro para prestar um serviço? Pra mim, Uber hoje no Brasil é prestação de serviços. Quando uso o Uber, me sinto consumindo um serviço, comprando, pagando por ele. (Raquel)

A entrevistada Carina também não se sente compartilhando ao usar Uber, sugerindo estar pouco predisposta a compartilhar nesse tipo de experiência na modalidade ofertada pela empresa, Uber Juntos:

E se eu não uso transporte público porque eu não me sinto segura de estar perto de outras pessoas, especialmente homens, imagina de pedir um Uber Pool (Uber Juntos) e dividir com outros homens... então eu prefiro não fazer esta opção. (Carina)

\subsection{2. \\ Motivos para se engajar na plataforma Uber}

Na revisão de literatura, Benoit et al. (2017) identificaram os motivos de engajamento em serviços do consumo colaborativo entre os consumidores: motivos econômicos, motivos sociais, valores hedônicos, redução de riscos e responsabilidades, benefícios ambientais. Nos depoimentos dos entrevistados, foram encontradas evidências de todos os motivos, sendo mais citados, os que indicavam evidências de redução de riscos e responsabilidades.

\section{$\checkmark$ Motivos econômicos}

Eu me apeguei ao Uber por causa do preço. Depois de usar bastante que eu fui criando outros vínculos com o aplicativo, com a empresa e tal. A porta de entrada foi o preço. (Miguel)

Basicamente eu uso o Uber por causa do preço, ele é mais barato que o taxi. (Clara)

O Uber, substituindo um pouco o táxi, ele gerou uma economia muito grande de custo por questão de bandeira dois. (Mateus) 
Comecei a usar Uber pelo preço do táxi, por ser mais barato (...) eu acho que cumpre a minha expectativa, eu quero um preço, não preciso estar num carro melhor. (Jonatan)

Eu comecei a usar o Uber porque era mais barato. (Camila)

Eu comecei a usar o Uber porque é mais fácil, não preciso estar com dinheiro, (...) mais confortável mesmo e também saía mais barato. (Carina)

Posteriormente ao começar a usar, notei a diferença no preço. (Joaquim)

Comecei a usar porque é mais prático, tem acesso você estando em qualquer lugar e pelo valor. (Pompeu)

$\checkmark$ Motivos sociais

Ao usar Uber e Airbnb, me sinto fazendo parte de uma tribo, pois é uma forma diferente de consumir. (Jonatan)

Sigo o Uber no Instagram. Comecei a seguir na parada gay do ano passado, que o Uber tinha um trio elétrico. (Miguel)

Baixei o aplicativo porque as minhas amigas disseram que poderíamos compartilhar o preço e ir para casa juntas. (Joana)

Também é bacana o fato de a maioria dos motoristas terem um nível cultural e sócio econômico compatível com a gente, o que permite diálogos construtivos. Pra mim, o motorista do Uber é como se fosse um amigo. Ele tem uma formação, um perfil sócio cultural parecido com o meu, ele é interessado em conversar com você. Não sinto isso com o motorista de taxi, que está ali prestando um serviço. (Joaquim)

Normalmente converso (com o motorista) Gosto de manter o contato, gosto de saber o que ele faz, eu gosto de saber o que ele tem pra oferecer e gosto de sentir se ele está contente ou não com o que ela está fazendo (...) pra mim é satisfatório, eu gosto, acho bacana. Pra mim e como se fosse uma troca. (Hanna)

\section{$\checkmark$ Valores hedônicos}

Eu não conhecia, aí um amigo disse que tinha chamado o Uber, e chegou um carro preto, de luxo, ele embarcou a mulher dele e o filho num carro com motorista... eu falei: "nossa, é assim que funciona!?". (Jonatan)

Eu peço o Black quando quero fazer uma presença, chegar num carro bacana, com um motorista particular. Também é bacana não ter que disputar um carro sendo que ele vem exclusivamente pra mim. (Joaquim)

\section{$\checkmark$ Benefícios Ambientais}

O mesmo carro está sendo usado por várias pessoas. Todas essas pessoas que usam, estão deixando de usar um carro a mais, o que é bom pro meio ambiente. (Joaquim)

O principal motivo alegado pelos entrevistados está relacionado à redução de riscos e responsabilidades. Tal achado retifica o que Benoit et al. (2017) postulam já que o consumo colaborativo promove um acesso temporário a um 
determinado recurso, reduzindo os riscos e responsabilidades envolvidos. No caso da utilização da Uber, estaria associado à aquisição e manutenção de um carro, à dificuldade de locais para estacionar nas cidades e a aspectos relacionados à segurança.

O benefício ambiental, por outro lado, citado por apenas um dos entrevistados mostra-se controverso, já que no Brasil, dirigir um carro para a Uber ou para outro aplicativo, tornou-se uma importante fonte de renda para muitas famílias, mesmo para quem não possui carro. Em seu site oficial, a Uber divulga parcerias firmadas com locadoras de veículos e estimula os motoristas-parceiros a utilizarem carros alugados, o que pode significar uma quantidade maior de veículos em circulação.

A comparação com o serviço de táxi é o principal fator quando se trata de motivos econômicos. Os motivos sociais apontados por alguns entrevistados indicam o senso de comunidade que se propõe no consumo colaborativo. Os valores hedônicos, identificados por dois entrevistados, adequam-se ao modelo de Benoit et al (2017), já que os entrevistados se referiram a situações onde desejavam possuir status.

A Tabela 5 indica os motivos para engajamento citados pelos entrevistados.

\begin{tabular}{|c|c|c|c|c|}
\hline $\begin{array}{c}\text { Motivos } \\
\text { econômicos }\end{array}$ & $\begin{array}{c}\text { Motivos } \\
\text { sociais }\end{array}$ & $\begin{array}{c}\text { Redução de } \\
\text { riscos e } \\
\text { responsabilidades }\end{array}$ & $\begin{array}{c}\text { Valores } \\
\text { hedônicos }\end{array}$ & $\begin{array}{c}\text { Benefícios } \\
\text { ambientais }\end{array}$ \\
\hline $\begin{array}{c}\text { Miguel } \\
\text { Mateus }\end{array}$ & $\begin{array}{c}\text { Miguel } \\
\text { Jonatan } \\
\text { Joana }\end{array}$ & $\begin{array}{c}\text { Joana } \\
\text { Carina }\end{array}$ & $\begin{array}{c}\text { Jonatan } \\
\text { Joaquim }\end{array}$ & Joaquim \\
Camilan & Joaquim & Rebeca & \\
Carina & Hanna & Lucas & \\
Joaquim & & Raquel & \\
Pompeu & & Luciana & & \\
& & João & & \\
& & Hanna & & \\
& & Jonatan & & \\
& & Pompeu & & \\
\hline
\end{tabular}

Tabela 5: Motivos para engajamento na plataforma Uber

Fonte: Elaboração própria. Adaptado de Benoit et al. (2017)

\subsection{3.}

\section{Sentimentos em relação às experiências na Uber}

De forma geral, as experiências relatadas pelos entrevistados foram relacionadas à sentimentos positivos, e a palavra tranquilidade e suas variações foram observadas em alguns depoimentos:

Tava voltando de uma festa com meu primo, e foi tranquilo, o rapaz fez um bom serviço, pegou a gente rapidinho, sabia onde a gente estava exatamente e me deixou onde eu pedi. (Rebeca) 
A Uber eu já utilizo há dois-três anos, e eu nunca tive nenhuma experiência negativa com o Uber. A última experiência foi boa, eu esperava demorar mais eu até fiquei preocupada de vir, mas foi um trajeto tranquilo, o motorista é muito simpático, não era muito de conversa, mas foi bem tranquilo, (...) foi uma viagem tranquila, demorou bem menos do que eu pensava. (Carina)

Eu pego o Uber com a maior tranquilidade pra não ter dor de cabeça de estacionar, um dos principais problemas aqui na zona sul pra mim, particularmente, é estacionar. (Mateus)

Eu já tive casos de amigas que perderam celular, perderam remédios, perderam bolsa no Uber, e fizeram uma ligação pro Uber e obtiveram resultado, as suas coisas de volta. (Hanna)

Quando esqueci uma carteira dentro do Uber e me devolveram com tudo dentro, sem estresse nenhum, foi bem rápido. (Rebeca)

Eu usei Uber Pool uma vez só. Porque eu vi que tinham duas mulheres no carro. Porque quando você pede aparece se já tem alguém, nesse caso já tinham duas pessoas, duas mulheres.... "ah tá, vou testar" e fui (...) a experiência foi tranquila, eram duas amigas, elas foram conversando, eu fui no banco da frente e foi tranquilo. Não teve nenhum problema não. (Luciana)

Já usei Uber Pool, foi tranquilo, porque era um menino, era gay, morávamos perto, a gente veio conversando, foi tranquilo, não tive muito estresse (Rebeca).

Mesmo tendo vivido uma experiência positiva na modalidade Uber Juntos, Rebeca alega ter medo ao usar o serviço e Mateus expôs o incômodo que sentiu ao compartilhar uma corrida com um estranho:

\section{Eu não uso por medo de quem possa entrar no Uber. (Rebeca)}

Em alguns casos eu usava a modalidade pool porque é mais barato, mas nunca tive o azar de cair alguém junto comigo, mas uma vez, particularmente, eu estava com pressa até de ir pro centro (...), o cara pediu o pool e o Uber deu uma desviada violenta pra ter que pegar o cara aí me atrasou e eu não gostei dessa experiência de ter que ir pra um lugar que na verdade não foi um lugar muito agradável que ele foi buscar o cara eu fiquei um pouco incomodado com a situação (...) achei perigoso. (Mateus)

Alguns entrevistados relataram experiências negativas relativas às atitudes do motorista.

Quando é motorista homem, eles são abusados e acabam interferindo na nossa vida e acabam "chegando" em mim ou nas minhas amigas. (...) foi desesperador, não sabia o que fazer naquela situação, eu voltei, tava conversando (...) me senti vulnerável (...) quando percebi, cortei o assunto e fiquei na minha, mexendo no celular, não falei mais nada. Mas você se sente mal porque não sabe (...) a pessoa, ela tá meio que no comando, no poder, você tá dentro do carro não sabe o que vai acontecer (...) Já aconteceu comigo e com amigas minhas. (Rebeca)

Outro dia digitei uma estação de metrô e estávamos perto da entrada e o motorista deu uma mega volta para atravessar a avenida e me deixar na entrada do metrô do outro lado da avenida. (Joaquim) 
Já teve um motorista que tava falando comigo pelo chat e mandou eu cancelar a corrida que ele não ia fazer. A partir do momento que você cancela a corrida, você paga. (Rebeca)

Uma vez eu estava em Jacarepaguá, e pedi um Uber, o motorista aceitou e demorou uns 10 minutos, o carro ficou parado. Percebi que ele estava demorando pra eu cancelar a viagem. (Clara)

O motorista decidiu ir por um caminho diferente do que o aplicativo estava sugerindo e deu errado, não foi muito legal. Eu me posicionei, fazendo com que ele entendesse que ali havia uma passageira, usuária do serviço, que ele precisava atender as minhas necessidades. (Raquel)

A entrevistada Camila descreveu uma experiência negativa vivida por sua mãe:

Á noite, ela saiu de um evento no centro, pediu Uber, aí ele não chegou e também não cancelou a corrida, então quer dizer, o celular dela ficou preso naquela corrida (...). Teve a cobrança, aí teve que ligar pra Uber e pedir para estornar no cartão (Camila).

\subsection{4. \\ O projeto da marca Uber}

Para recompor o projeto da marca Uber neste trabalho, foram utilizados o site oficial da empresa e o filme publicitário da campanha "Confiança começa com o nome", veiculada em 2018.

Segundo fontes na empresa, a campanha "Confiança começa com o nome" foi a primeira realizada no Brasil voltada para a construção da marca. Até então, as campanhas não tinham esse objetivo, eram meramente transacionais, não visavam a conexão com a marca.

\subsubsection{1. \\ Informações do site da empresa}

A marca Uber é descrita em seu site oficial brasileiro como "A mobilidade que você deseja". A comunicação no site é direcionada aos usuários e às pessoas interessadas em dirigir, conforme trechos apresentados abaixo, respectivamente:

Dirija

Dirija quando quiser. Encontre oportunidades perto de você.

Oportunidades em todo lugar. Ganhe o seu dinheiro, dirija no seu tempo e conquiste seus objetivos.

Viaje

Peça uma viagem para onde quiser, com um toque no seu telefone.

$A$ viagem que você deseja. Solicite uma viagem, entre no carro e relaxe. 
Nas seções quem somos, o que oferecemos e como a Uber funciona, a marca se apresenta da seguinte forma:

QUEM SOMOS Criamos oportunidades ao colocar o mundo em movimento Quando as pessoas têm mobilidade, tudo é possível. As oportunidades surgem, as portas se abrem e os sonhos se tornam realidade. A tecnologia que começou como uma forma de pedir uma viagem com o toque de um botão já possibilitou bilhões de conexões entre pessoas no mundo todo.

O QUE OFERECEMOS Viagens e muito mais

Além de ajudar você a se locomover, estamos trabalhando para trazer o futuro até você com a tecnologia de carros semiautônomos e com o transporte aéreo urbano, ajudando as pessoas a pedir entrega de comida de forma rápida e econômica, facilitando o acesso à assistência médica, criando novas soluções para o transporte de cargas e possibilitando que as empresas simplifiquem as viagens de colaboradores.

COMO A UBER FUNCIONA Nosso principal serviço é uma tecnologia de transporte sob demanda, e o que torna isso possível é o app que conecta motoristas parceiros e usuários.

Na seção Fatos e Dados sobre a Uber (Uber Newsroom), há ainda o texto:

A Uber é uma empresa de tecnologia que está transformando a maneira como pessoas se movimentam. Ela conecta usuários e motoristas parceiros por meio de seu app.

\subsubsection{2.}

\section{Filme publicitário campanha "Confiança começa com o nome"}

O filme publicitário, integrante da campanha "Confiança começa com o nome"1, veiculado em 2018, possui sessenta segundos e apresenta sete discursos distintos.

Tais discursos serão analisados em separado, através das cenas que os compõem (Figuras 8 a 14) e, para cada discurso, serão identificados os elementos presentes: temas e figuras e, a partir daí a narrativa global, bem como os valores, de acordo com a organização semionarrativa do significado (SEMPRINI, 2010).

\footnotetext{
${ }^{1}$ Filme publicitário disponível no Youtube: $w w w . y o u t u b e / w a t c h ? v=K k A u 6 w N g 31 Y$
} 
$\checkmark$ Discurso 1 - cenas 1 a 4

Cena 1

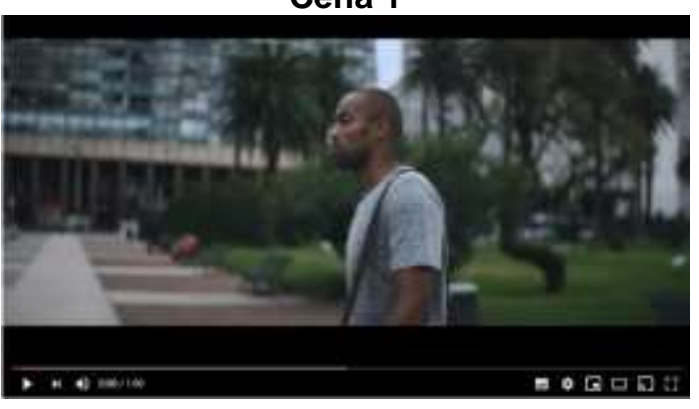

Cena 3

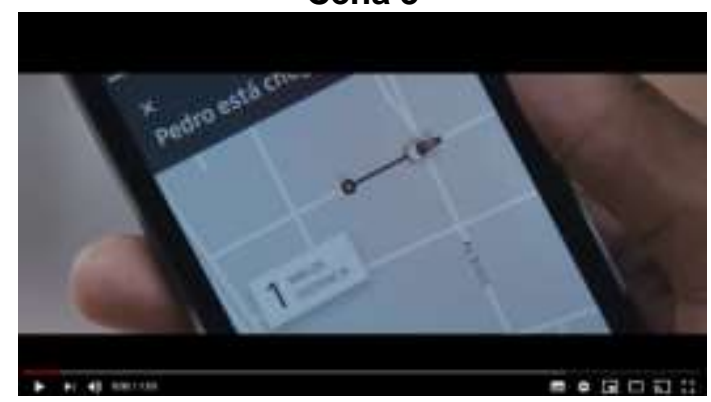

Cena 2

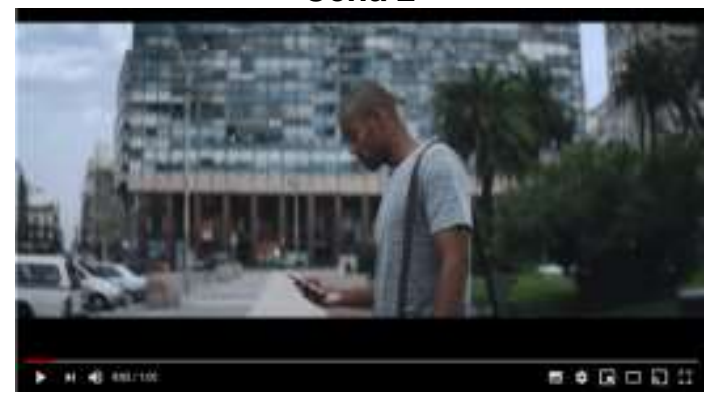

Cena 4

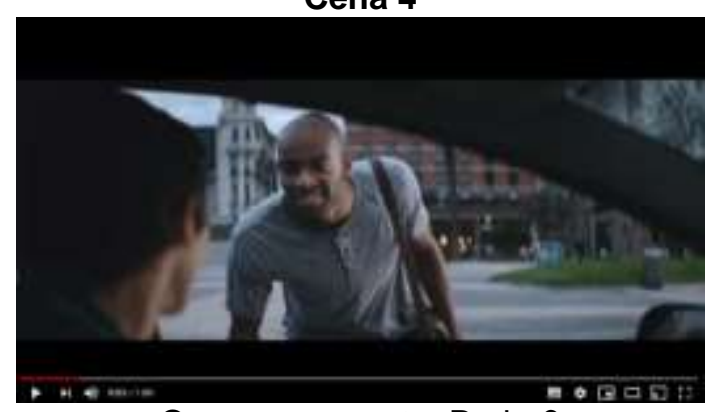

O rapaz pergunta: Pedro?

O motorista pergunta: Pedro?

Os dois riem da coincidência.

Figura 8: Cenas 1 a 4 do filme publicitário "Confiança começa com o nome"

Fonte: Elaboração própria. Adaptado de: https://www.youtube.com/watch?v=KkAu6wNg31Y

$\checkmark$ Discurso 2 - cena 5

\section{Cena 5}

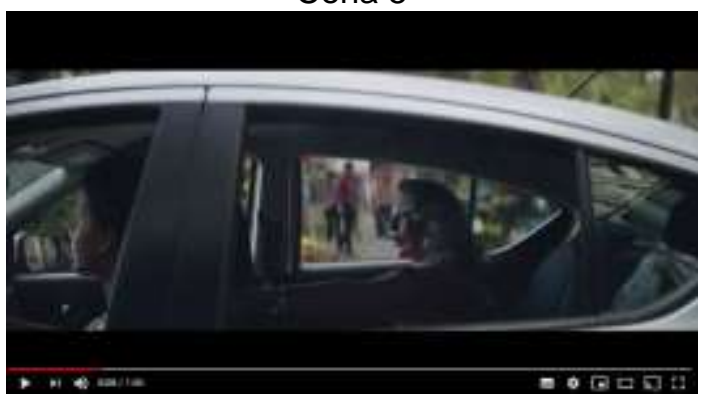

A passageira diz: Até logo Fernanda!

A motorista responde: Tchau, tchau, Helena.

Figura 9: Cena 5 do filme publicitário "Confiança começa com o nome"

Fonte: Elaboração própria. Adaptado de: https://www.youtube.com/watch?v=KkAu6wNg31Y 
$\checkmark$ Discurso 3 - cena 6

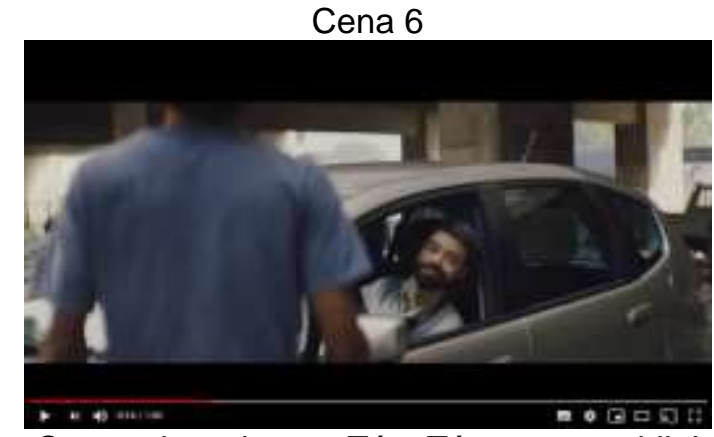

O motorista chama: Téo, Téo, sua mochila!

Téo responde: Noooossa, obrigado Luis!

Figura 10: Cena 6 do filme publicitário "Confiança começa com o nome"

Fonte: Elaboração própria. Adaptado de: https://www.youtube.com/watch?v=KkAu6wNg31Y

\section{Discurso 4 - cenas 7,8 e 9}

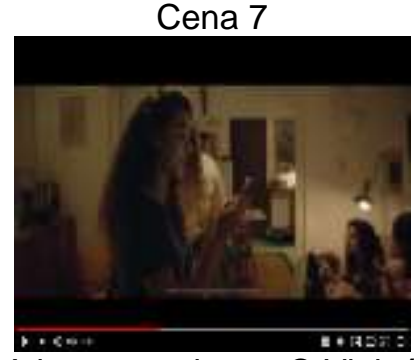

A jovem exclama: O Vini tá chegando!!!!

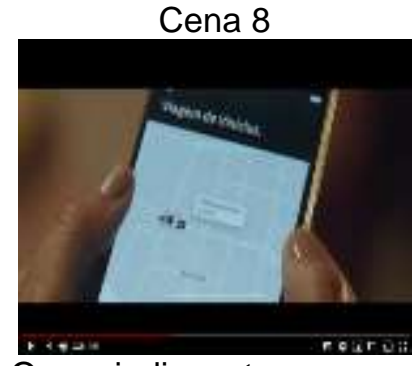

O app indica o tempo para chegada

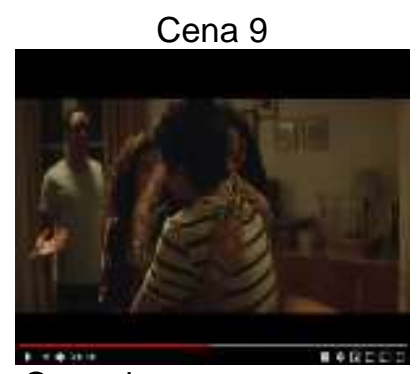

Os amigos comemoram: Vini!!!!!

Figura 11: Cenas 7 a 9 do filme publicitário "Confiança começa com o nome"

Fonte: Elaboração própria. Adaptado de: https://www.youtube.com/watch?v=KkAu6wNg31Y

$\checkmark$ Discurso 5 - cenas 10, 11 e 12

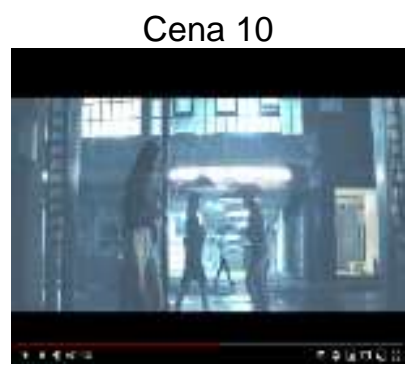

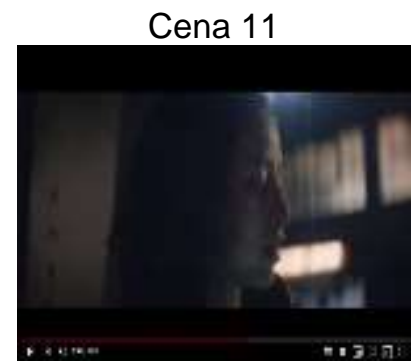

A mulher olha para cima e diz: Jesus, Maria

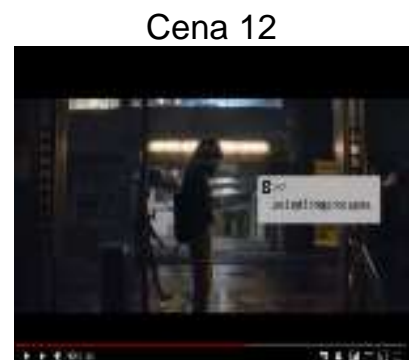

Ela lê o nome do motorista no app: José?!?!?

Figura 12: Cenas 10 a 12 do filme publicitário "Confiança começa com o nome"

Fonte: Elaboração própria. Adaptado de: https://www.youtube.com/watch?v=KkAu6wNg31Y 
$\checkmark$ Discurso 6 - cenas 13 a 18
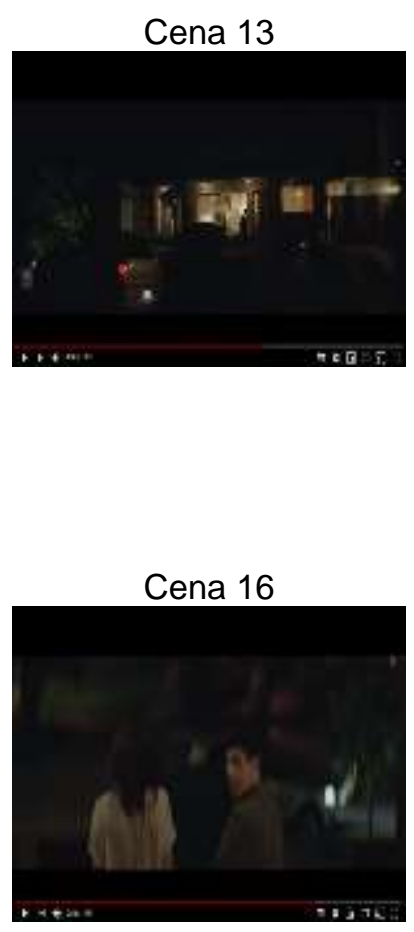

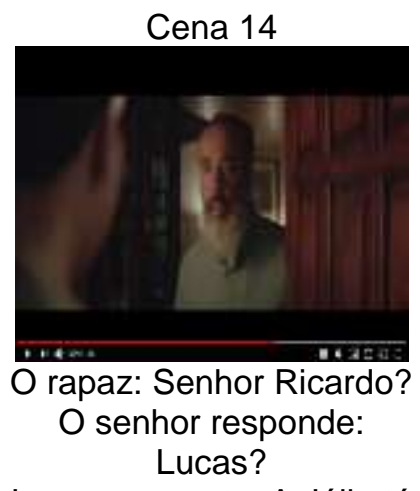

Lucas pergunta: A Júlia tá aí?

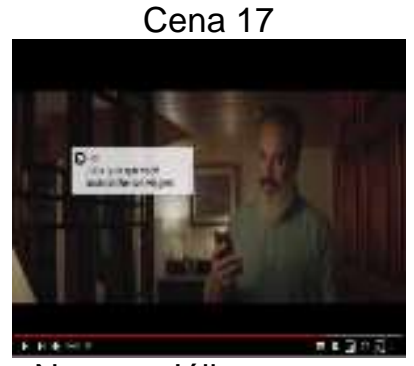

$$
\begin{gathered}
\text { No app: Júlia quer que } \\
\text { você acompanhe sua } \\
\text { viagem }
\end{gathered}
$$

Figura 13: Cenas 13 a 18 do filme publicitário "Confiança começa com o nome" Fonte: Elaboração própria. Adaptado de: https://www.youtube.com/watch?v=KkAu6wNg31Y

\section{$\checkmark$ Discurso 7 - cenas 19 a 23}

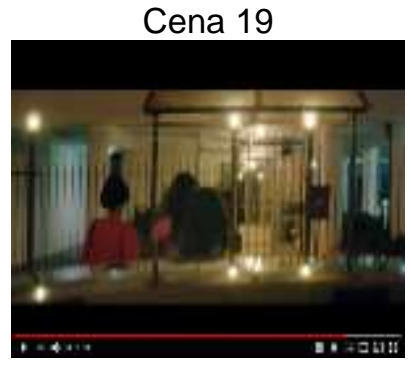

Cena 22

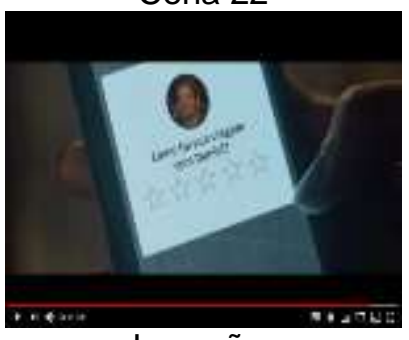

Locução:

Confiança começa com um nome

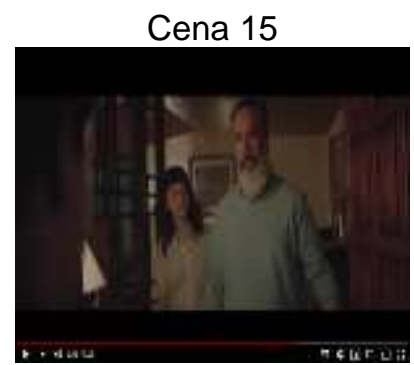

O pai responde: Não! Júlia surge e diz: Pai?!?!?

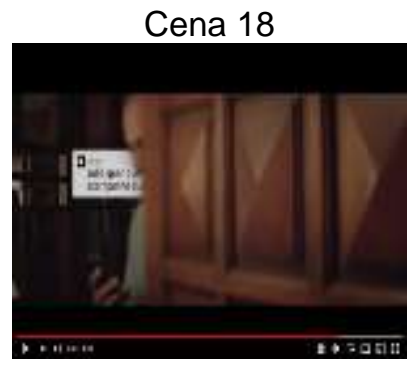

Figura 14: Cenas 19 a 23 do filme publicitário "Confiança começa com o nome"

Fonte: Elaboração própria. Adaptado de: https://www.youtube.com/watch?v=KkAu6wNg31Y 
A Tabela 6 exibe as evidências encontradas para cada discurso presente no filme publicitário da campanha "Confiança começa com o Nome", seguindo a organização semionarrativa do significado (SEMPRINI, 2010).

\begin{tabular}{|c|c|c|c|}
\hline Discurso & Tema & Figuras & Valores \\
\hline 1 & Atendimento amigável & $\begin{array}{l}\text { Rapaz se deslocando } \\
\text { Cidade, prédios } \\
\text { Aplicativo } \\
\text { Motorista amigável } \\
\text { O nome }\end{array}$ & Conveniência \\
\hline 2 & Inclusão & $\begin{array}{l}\text { Idosa } \\
\text { Motorista mulher, negra } \\
\text { Os nomes }\end{array}$ & $\begin{array}{l}\text { Confiança } \\
\text { Conveniência }\end{array}$ \\
\hline 3 & Honestidade & $\begin{array}{l}\text { Mochila devolvida } \\
\text { O nome }\end{array}$ & $\begin{array}{l}\text { Confiança } \\
\text { Segurança }\end{array}$ \\
\hline 4 & $\begin{array}{l}\text { Eficiência } \\
\text { Tecnologia }\end{array}$ & $\begin{array}{l}\text { Festa surpresa } \\
\text { Aplicativo } \\
\text { Amigos esperando } \\
\text { O nome }\end{array}$ & $\begin{array}{l}\text { Confiança } \\
\text { Conveniência }\end{array}$ \\
\hline 5 & Imprevisibilidade & $\begin{array}{l}\text { Chuva à noite } \\
\text { Cidade } \\
\text { Mulher sozinha } \\
\text { Aplicativo } \\
\text { "Milagre" } \\
\end{array}$ & $\begin{array}{l}\text { Confiança } \\
\text { Segurança } \\
\text { Conveniência }\end{array}$ \\
\hline 6 & Controle parental & $\begin{array}{l}\text { O pai } \\
\text { A jovem e o namorado } \\
\text { Noite } \\
\text { Aplicativo } \\
\text { Os nomes }\end{array}$ & $\begin{array}{l}\text { Confiança } \\
\text { Segurança }\end{array}$ \\
\hline 7 & $\begin{array}{l}\text { Vulnerabilidade da } \\
\text { mulher }\end{array}$ & $\begin{array}{l}\text { Amigas alegres } \\
\text { Noite } \\
\text { Volta para casa } \\
\text { O nome } \\
\text { Avaliação no aplicativo }\end{array}$ & $\begin{array}{l}\text { Segurança } \\
\text { Conveniência } \\
\text { Confiança }\end{array}$ \\
\hline
\end{tabular}

Tabela 6: Organização semionarrativa do significado do filme da campanha publicitária "Confiança começa com o nome"

Fonte: Elaboração própria. Adaptado de Semprini (2010)

Embora o filme se desdobre em sete discursos com temas distintos, todos possuem o mesmo nível narrativo e trabalham os valores conveniência, confiança e segurança, na mesma proporção.

Depreende-se que a narrativa global do filme da campanha publicitária "Confiança começa com o nome" é: A Uber coloca o sujeito/consumidor em conjunção com transporte confiável e seguro em qualquer circunstância. 


\subsubsection{3.}

\section{Recomposição do projeto de marca}

Com base na exploração feita no conteúdo do site da análise do significado da narrativa do filme publicitário da campanha "Confiança começa com o nome", serão identificados os elementos do projeto de marca conforme o modelo Projeto/Manifestação (SEMPRINI, 2010):

\section{$\checkmark$ Enunciação Fundamental}

A enunciação da marca é a justificativa de sua legitimidade para existir (SEMPRINI, 2010). Com base no conteúdo analisado, pode-se entender que a enunciação fundamental da marca Uber consiste em oferecer mobilidade, conveniência e conforto, dando ao usuário possibilidades de escolha, oportunizando a realização de desejos e objetivos, através da tecnologia.

\section{$\checkmark$ Promessa}

A promessa é a transformação e direcionamento da enunciação ao contexto e ao público da marca. Nessa etapa, são encontradas as vantagens que o público pode obter através das competências da marca (SEMPRINI, 2010). Os trechos da página principal descritos anteriormente, bem como as narrativas extraídas do filme, ilustram essas vantagens e podem explicitar a promessa da marca Uber, tanto para o público de usuários como para o de interessados em dirigir.

Pode-se depreender que a promessa da marca Uber é ser uma marca confiável, conveniente e acessível, que oferece segurança e conforto no serviço (benefícios para os usuários) e que oportuniza ganhos financeiros, aliando liberdade, flexibilidade e à concretização de objetivos (benefícios para os interessados em dirigir).

$\checkmark$ Especificação da promessa

A especificação da promessa é a sua originalidade, seu caráter único (SEMPRINI, 2010), o que a diferencia da concorrência.

Peça uma viagem para onde quiser, com um toque no seu telefone.

Ganhe o seu dinheiro, dirija no seu tempo e conquiste seus objetivos. 
Viagens e muito mais. Além de ajudar você a se locomover, estamos trabalhando para trazer o futuro até você com a tecnologia de carros semiautônomos e com o transporte aéreo urbano, ajudando as pessoas a pedir entrega de comida de forma rápida e econômica, facilitando o acesso à assistência médica, criando novas soluções para o transporte de cargas e possibilitando que as empresas simplifiquem as viagens de colaboradores.

Pela análise do conteúdo do site conforme trechos acima transcritos e das cenas do filme, depreende-se que a Uber é competente em prover uma tecnologia simples e acessível para conectar pessoas interessadas na mobilidade a motoristas. Somado a isso, destaca-se a oferta de conveniência, dando aos usuários a possibilidade de escolher quando e para onde ir.

$\checkmark$ Inscrição da promessa em um ou vários territórios

É o momento da concretização da enunciação da marca, no qual a promessa torna-se uma oferta (SEMPRINI, 2010). Ao ser lançada em 2009, a marca propunha-se a prover um serviço de alto padrão, conectando usuários a motoristas particulares, através de um aplicativo para celular. Buscando viabilizar a plataforma e tornar-se mais competitiva, a empresa lançou novos serviços como - Uber $X$ e o Uber Juntos, com carros compactos e preços acessíveis, o que facilitou sua expansão para outros países e maior penetração no mercado. A marca chegou ao Brasil em 2014, com o produto original, o Uber Black, mas logo em seguida lançou os serviços Uber X, Uber Juntos e Uber Select. Ainda em ridesharing, a marca estuda lançar as modalidades com bicicletas e patinetes elétricos, já em teste no mercado americano. Há também o serviço Uber Eats, para transporte de comida.

Pela análise do trecho descrito na especificação da promessa, nota-se que a marca se inscreve em outros territórios de mobilidade, que não apenas o de passageiros, como o aéreo, de comida, de colaboradores de empresas, cargas, além do acesso à assistência médica. No filme, entretanto, é evidenciado apenas um território, o de viagens compartilhadas (ridesharing).

Outros territórios descritos no site brasileiro não são ofertados no país, como: serviços de transporte aéreo (UberAir), acesso à assistência médica (UberHealth), de cargas (Uber Freight) e iniciativas com veículos semiautônomos.

\section{$\checkmark$ Valores da marca}

Os valores da marca são os elementos que permitem à marca demonstrar sua atitude e que possibilitam que a marca se conecte aos valores do contexto e 
socioculturais (SEMPRINI, 2010). Pela análise realizada, torna-se possível identificar alguns valores presentes no projeto da marca Uber, conforme será visto a seguir.

\section{Valor Segurança}

Viagens e cidades mais seguras

A segurança de usuários e motoristas parceiros é essencial. Estamos comprometidos a fazer a nossa parte, utilizando a tecnologia para contribuir com a sua tranquilidade. Além disso, temos parcerias com organizações e autoridades e estamos desenvolvendo novas tecnologias e sistemas para ajudar a criar um mundo com mais mobilidade e segurança para todos.

Nosso compromisso é melhorar a segurança para todos usuários e motoristas. Estamos introduzindo novos recursos de segurança, que vão desde melhorar o processo de cadastro dos motoristas parceiros até oferecer tranquilidade dentro do carro, para que você se sinta seguro e conectado em cada viagem.

Não estamos mudando apenas o transporte com a nossa tecnologia. Estamos construindo uma cultura dentro da Uber que enfatiza fazer o que é certo, sem exceção, para usuários, motoristas parceiros e colaboradores.

Usamos a tecnologia para adicionar camadas de segurança antes, durante e depois de cada viagem

A campanha "Confiança começa com o nome", sugere a intenção de reforçar o valor segurança através de elementos presentes em algumas cenas do filme: o uso do nome dos motoristas e passageiros (Cenas 3, 4, 5, 6, 7, 8, 9, 12, 14 e 20), pessoas se deslocando a noite (Cenas 12, 16 e 19), o pai acompanhando a viagem da filha (Cena 17), a mulher sozinha, na chuva, à noite (Cena 10), as jovens voltando para casa à noite (Cena 19), o motorista que devolve a mochila esquecida (Cena 6).

\section{Valor Conveniência}

Todas as cenas nas quais surgem imagens do aplicativo (Cenas 3, 8, 12, 17 e 22) com a localização do motorista, tempo de espera, possibilidade de acompanhamento da viagem e avaliação do motorista, evidenciam o valor conveniência, representado pela facilidade em se usar o aplicativo, em qualquer lugar, a qualquer momento.

As cenas do filme que indicam o tempo de espera do motorista (Cenas 3, 8 e 12), a cena da mulher na chuva solicitando um carro (Cena 12), a cena na qual três amigas estão voltando à noite para casa (Cena 19) e a na qual a jovem Júlia sai com o namorado, também a noite (Cena 16), sugerem o reforço do valor conveniência. Tal valor é ainda ratificado no trecho do site:

Peça uma viagem para onde quiser. 


\title{
Valor Qualidade
}

Tal valor é ressaltado nos trechos do site abaixo, e está implícito nas figuras utilizadas em duas cenas do filme: na que indica a possibilidade de avaliação do motorista no aplicativo (Cena 22) e também na que demonstra a conduta correta do motorista ao devolver a mochila (Cena 6).

Nosso compromisso é melhorar a qualidade das suas viagens Como o nosso compromisso é sempre oferecer uma viagem 5 estrelas, agora ficou mais fácil dar feedback, reconhecer motoristas que prestam serviços excepcionais e muito mais.

Feedback constante entre usuário - motorista parceiro. O que garante o nível de qualidade da plataforma Uber é o sistema de avaliação mútua, onde usuários avaliam os motoristas parceiros e vice-versa.

\section{Valor Inovação}

O valor inovação é associado à tecnologia, conform trechos do site:

A Uber é uma empresa de tecnologia que está transformando a maneira como pessoas se movimentam.

\begin{abstract}
A Uber oferece uma plataforma tecnológica para que motoristas parceiros se conectem de forma fácil e descomplicada a usuários que buscam viagens acessíveis e confortáveis.
\end{abstract}

Nosso principal serviço é uma tecnologia de transporte sob demanda.

Estamos trabalhando para trazer o futuro até você com a tecnologia de carros semiautônomos e com o transporte aéreo urbano...

\section{Valor Diversidade (Inclusão)}

A marca também reforça o valor diversidade passagens do site e tal valor fica evidente através das figuras utilizadas no filme publicitário (mulheres, idosos, jovens, negros).

Compromisso com a diversidade. Nosso objetivo é criar um local de trabalho inclusivo e que represente a diversidade das cidades que atendemos, onde cada pessoa possa ser ela mesma e a autenticidade seja celebrada.

"A Uber representa o melhor avanço em mobilidade para pessoas com deficiências visuais da última década. " (Mike May, presidente da Lighthouse for the Blind)

"Para criar um ambiente onde todos possam ser quem realmente são, onde as pessoas se sintam engajadas e onde as melhores ideias sejam escolhidas, é preciso ter perspectivas diferentes que só podem se concretizar com diversidade, inclusão e reconhecimento. " (Amandine Aman, Diretora de Alinhamento de Marketing Global da Uber)

Temos um compromisso sólido com o futuro de todos. De que forma? Reimaginando cidades, colaborando com a segurança das comunidades, defendendo a inclusão e a diversidade e ajudando a oferecer novas oportunidades para todos. 


\section{Valor Confiança}

Embora a marca não utilize a palavra confiança com frequência nos textos do site, tal valor além de dar título à campanha "Confiança começa com o nome", está evidente nos discursos do filme publicitário. As cenas da mochila sendo devolvida ao passageiro (Cena 6), do pai que fecha a porta ao acompanhar a viagem da filha (Cena 18), das amigas que voltam juntas para casa à noite (Cena 20), da mulher que está na chuva a noite (Cena 12), demonstram isso.

A Cena 7, na qual os amigos esperam o "Vini" para a festa surpresa, reforça ainda a confiabilidade no aplicativo. A certeza de que as informações do aplicativo estão corretas, torna a celebração possível.

Outro recurso é a utilização do nome do motorista ou do passageiro na maioria das cenas. Tal construção pode indicar que, através de uma relação mais próxima, a utilização do serviço se torna mais segura e confiável.

Pela análise dos trechos do site e da narrativa global do filme publicitário da campanha Confiança começa com o nome, depreende-se que os valores nos quais a marca está fundamentada são: conveniência, confiança, inovação, qualidade, segurança e diversidade.

Ao aplicar tais valores à axiologia do consumo (FLOCH, 1993), observa-se que o valor segurança considerado valor de base, fica evidente no discurso da marca "A segurança de usuários e motoristas parceiros é essencial". Outro valor utópico encontrado é a diversidade. Em oposição, um valor crítico, que é a qualidade, surge no texto: "Como o nosso compromisso é sempre oferecer uma viagem 5 estrelas (...)". Passando aos valores práticos, que são conveniência, confiança e inovação. A inovação é representada pela tecnologia, que é a forma pela qual a Uber entrega seu serviço. Não foram encontradas evidências de valorização lúdica na recomposição do projeto da marca.

Os tipos de valorização encontrados no projeto da marca Uber, formam o quadrado semiótico da Figura 15. 


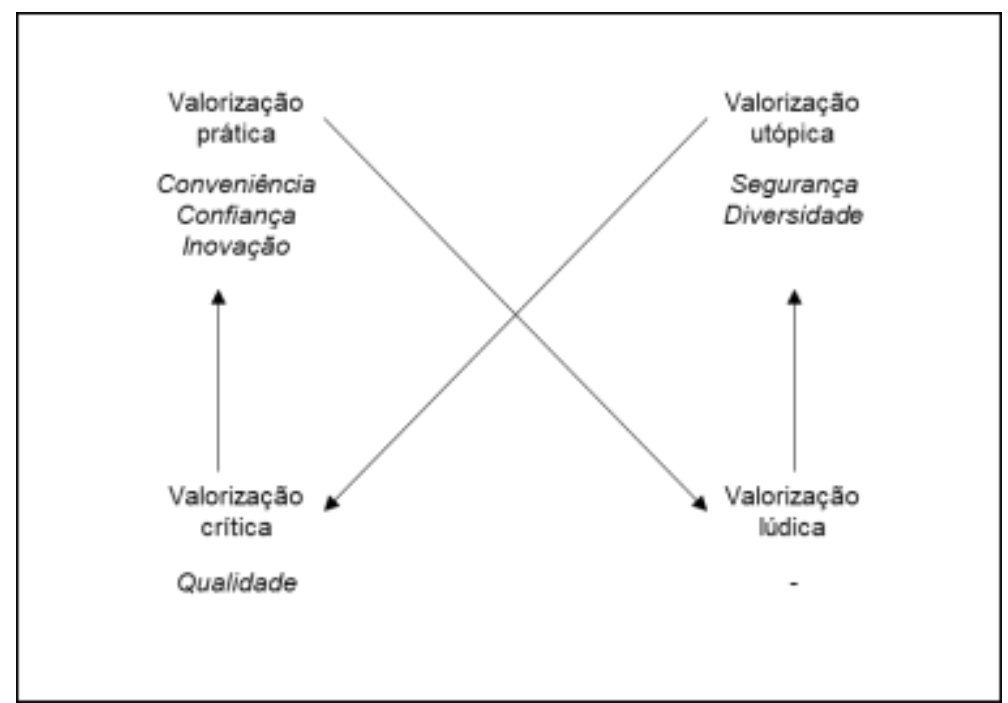

Figura 15: Tipos de valorização encontrados no projeto da marca Uber Fonte: Elaboração própria. Adaptado de Floch (1993, p. 148)

Após recompor o projeto da marca Uber através de seus cinco componentes, entende-se que tal projeto pode ser resumido da seguinte forma: ser uma marca segura e confiável, que cria oportunidades para todos (diversidade), oferecendo conveniência, através de viagens com qualidade, facilitadas pela tecnologia (inovação).

\subsection{5.}

\section{As manifestações da marca Uber na perspectiva do consumidor}

Foram três as manifestações da marca Uber selecionadas para análise pelos consumidores: o serviço Uber X, o aplicativo para dispositivos móveis e a Campanha publicitária "Confiança começa com o nome", composta pelo filme e por anúncios (Anexo 7.4). As observações dos entrevistados serão analisadas seguindo o modelo proposto por Semprini (2010), buscando a organização semionarrativa do significado, considerando cada manifestação como um enunciado em si. 


\subsubsection{1.}

\section{Manifestação Serviço Uber X}

\subsubsection{1. Nível do discurso na manifestação Serviço Uber $\mathbf{X}$}

O nível do discurso é "aquele no qual valores e narrações são enriquecidos pelas figuras do mundo: objetos, formas, cores, personagens, estilos, slogans, logos, etc." (Semprini, 2010 p. 154). Nesse nível, podem ficar evidenciados os atributos da marca.

$\mathrm{Na}$ manifestação serviço Uber $\mathrm{X}$, foram identificados alguns temas como: valor do serviço (preço), segurança, confiança, conveniência, qualidade e diversidade/inclusão.

Nos discursos relacionados ao valor do serviço (preço), a maioria dos entrevistados faz uma comparação, favorável ou desfavorável com outros serviços, sejam eles de transporte privado ou público, conforme trechos abaixo:

Baixei o aplicativo porque as minhas amigas disseram que poderíamos compartilhar o preço, ir para casa juntas. Se a gente compartilhasse o preço, saía mais barato que uma passagem de ônibus. (Joana)

Uso o Uber porque é mais barato que o taxi. (Raquel)

Comecei a usar Uber na época que se popularizou, pelo preço, que era mais competitivo do que o táxi, era mais barato, e desde então eu só uso o Uber. (Miguel)

Comecei a usar o Uber porque o valor do táxi estava muito caro (...) saía mais barato. (Carina)

Se eu estou pegando um prestador de serviços que não é profissional, que seja mais barato. (João)

O Uber, substituindo um pouco o táxi, ele gerou uma economia muito grande de custo por questão de bandeira dois. (Mateus)

Hoje em dia eu estou usando o (concorrente). Mas por questão de preço, porque tem mais promoção e eu acho que o serviço está bem parecido com o Uber. Até porque na maioria das vezes é o mesmo motorista que tem vários aplicativos pelo que eu entendo. (...) No início os carros chegavam mais rápido, então justificava pagar um pouco mais para usar Uber. (Luciana)

O Uber é bem mais barato que o táxi, mas está mais caro que o 99. (Clara)

Geralmente o (concorrente) apresenta um valor menor que o Uber, ele sempre tá fazendo mais promoções que o Uber, aí eu uso. Mesmo assim, eu ainda uso mais o Uber. (Rebeca)

Comecei a usar Uber pelo preço do táxi, por ser mais barato (...) eu acho que cumpre a minha expectativa, eu quero um preço, não preciso estar num carro melhor. (Jonatan)

Uso porque é muito mais barato que o táxi. (Joaquim) 
O preço é excelente, tranquilo. (Hanna)

Outro aspecto presente no discurso dos entrevistados foi o da segurança, conforme trechos destacados a seguir:

Me sinto segura porque ele de pronto me informa quem vai me buscar, em que carro vem, qual nome, qual a placa, então como eu moro num condomínio fechado, isso também me ajuda, porque eu me cerco de segurança pra mim e eu deixo o condomínio informado também pra onde eu vou e com quem eu vou. (Hanna)

Uso quando vou num lugar onde você não queira ir de carro porque é perigoso, acabo optando pelo aplicativo. (Mateus)

Eu comecei a usar o Uber, porque não tava mais me sentindo segura com transporte público, por conta de assédio e (...) nunca sofri nenhum tipo de assédio no Uber (...) Me sinto mais segura usando o aplicativo do que no transporte público. (Carina)

Eu sou homem, me sinto seguro, não me sinto vulnerável. (Joaquim)

Eu acho que o Uber é mais seguro. Eu não me lembro de ter acontecido uma situação abusiva com o Uber. (Joana)

A entrevistada Joana, contudo, embora tenha considerado o Uber mais

seguro", relatou sentimentos contrários em outros trechos de sua entrevista:

A questão dele ser um homem é o que preocupa mais. Você tá entrando no carro dele, um lugar fechado, é ele que tá monitorando prá onde que ele está indo, ele pode me sequestrar. Fico muito tranquila quando é uma motorista mulher. (Joana)

Porque existem situações em que o cara que tá dirigindo o carro pode ser completamente abusivo. A gente tem medo porque todo homem pode ser um estuprador em potencial. E aí, quando é uma mulher, a gente fica muito mais tranquila. A gente sabe que uma mulher não vai estuprar a gente. (Joana)

Rebeca compactua do mesmo desconforto e o relato do entrevistado Joaquim corrobora o sentimento das entrevistadas.

Quando é motorista homem, eles são abusados e acabam interferindo na nossa vida, acabam chegando em mim ou nas minhas amigas (...) principalmente quando você está vindo sozinha, parece estar mais vulnerável a esse tipo de constrangimento. (Rebeca)

Existem situações em que o cara que está dirigindo pode ser completamente abusivo, a gente tem medo. (Rebeca)

Mas penso que, para uma mulher, esse é um aspecto preocupante, porque ela nunca sabe quem vai encontrar. Ela pode estar exposta. (Joaquim)

Ao ser questionada se já havia passado por alguma situação do tipo, a entrevistada Rebeca relata: 
Sim, foi desesperador, não sabia o que fazer naquela situação, eu voltei, tava conversando (...) quando percebi, cortei o assunto e fiquei na minha, mexendo no celular, não falei mais nada. Mas você se sente mal porque não sabe (...) a pessoa, ela tá meio que no comando, no poder, você tá dentro do carro não sabe o que vai acontecer (...) Já aconteceu comigo e com amigas minhas. (Rebeca)

Lucas e Joaquim destacam aspectos negativos da segurança, na utilização do serviço:

Comparado ao Uber, eu tenho a impressão que o motorista de taxi ele passa por um processo de credenciamento mais profundo. As pessoas têm um back ground, elas têm que conseguir se filiar ao aplicativo, além disso, tem que conseguir a licença ou trabalhar para alguém que tenha a licença (Lucas).

Os motoristas do Uber não são profissionais do volante e não tem preparo de "direção defensiva, por exemplo, ou seguro diferenciado cobrindo terceiros.

Outro tema identificado nos discursos foi a confiança:

Tenho muita confiança no Uber, nunca tive grandes decepções com a empresa. (Miguel)

Confio sim, vejo a placa e pergunto o nome. Nunca tive problema. (Clara)

No final da corrida, peguei os dados do motorista e passei para a minha esposa, porque se em algum momento, ela vai bastante pra Brasília, se em algum momento ela precisar, tem agora uma pessoa que eu considero de confiança. (Lucas)

Para mim, os três (concorrentes) são confiáveis, não tem nenhum problema com os três, tenho cadastro nos três: Uber, 99 e Cabify, e o que aparecer primeiro, eu uso. (Mateus)

Eu confio mais no Uber. Eu tenho confiança no Uber porque eu acho que a marca pede um pouco mais das pessoas, pede um pouquinho mais de responsabilidade, de assiduidade, de comprometimento com o cliente, 99 eu acho meio solto. (Hanna)

Eu já tive casos de amigas que perderam celular, perderam remédios, perderam bolsa no Uber, e fizeram uma ligação pro Uber e obtiveram resultado, as suas coisas de volta. (Hanna)

Foram identificados ainda aspectos relacionados à qualidade do serviço, mais positivos que negativos. Dentre os positivos, a tangibilização da qualidade se dá através da postura do motorista-parceiro, de seu domínio e experiência, conforme relatos a seguir:

Chamei o Uber e tive a grata surpresa de ser um motorista simpaticíssimo, com um ótimo carro e como eu sabia que eu precisava voltar no dia seguinte eu combinei com ele, dele estar no horário pra me buscar e ele foi tão atencioso que ele se prontificou a chegar meia hora antes e ficar me esperando porque ele estava muito preocupado com o trânsito. Ele achava que tinha o risco de perder o avião de volta porque eu tinha marcado um horário muito apertado. A experiência foi maravilhosa, ele de fato estava lá no dia seguinte, meia hora antes e quando eu precisei ele estava pronto pra sair. (Lucas) 
Uma vez eu peguei o Uber no período de Natal, tava muito engarrafado, o Uber conhecia o local (...), conseguiu entrar pelas ruas e fugiu do engarrafamento $e$ poupar tempo. (Miguel)

A experiência foi boa, eu esperava levar mais tempo, mas foi um trajeto tranquilo, o motorista muito simpático, não era muito de conversa, mas foi bem tranquilo, ele perguntou qual a rota que eu queria e eu acho que isso é fundamental ter (...) nunca tive nenhuma experiência negativa com o Uber (Carina).

Eu já peguei Uber aí com aguinha, com balinha, super solícitos, dando dica de lugares, estava fazendo programa de visitas com turistas, enfim, então já tive pontos muito positivos com esse aplicativo de transporte com motoristas. (Mateus)

Uma outra forma encontrada para tangibilizar a qualidade do serviço é o carro como demonstram as falas da entrevistada Hanna:

Eu nunca tive nenhuma experiência ruim com o Uber, nunca vi carro sujo, só carros limpos. (Hanna)

Porque eu sei que a pessoa que tem o Uber, em outro tempo, vai estar pegando a esposa, levando ao mercado, pegando o filho, levando ao médico, indo ao banco pagar suas contas, (...) ele tem mais responsabilidade com aquilo, ele tem mais compromisso, não dissocia do dia a dia dele. $O$ taxi as vezes o cara deixa em casa, encostado e pega o outro carro e vai fazer as coisas. O Uber não, o cara faz tudo com aquele mesmo carro. Ele estende a empatia que ele tem com a família dele para as outras pessoas. (Hanna)

O entrevistado Jonatan, no entanto, ressalta que a qualidade para ele não está relacionada ao carro, mas sim ao conforto oferecido pelo serviço:

Eu acho que cumpre a minha expectativa, tem que ter no mínimo assim, o que eu exijo é um ar condicionado. Mas qualidade do carro não me interfere... eu quero é o preço e o ar condicionado, o conforto do ar condicionado, só. (Jonatan)

Dentre os aspetos negativos associados à qualidade, novamente surgem relatos que relacionam a falta de qualidade à postura dos motoristas-parceiros e comparações com os concorrentes:

No início os carros chegavam mais rápido, hoje em dia não (...) eu acho que o serviço (dos concorrentes) é meio parecido. Antes o do Uber era um pouco melhor, aí depois entrou o Cabify, os motoristas do Cabify eu achava que eram um pouco mais simpáticos (...) mas hoje em dia eu acho que eles são as mesmas pessoas sabe, eu sinto isso. (Luciana)

Eu vejo o cara do Uber mais preocupado em achar o caminho, ficar com a cara enfiada no GPS sem saber onde que vira, do que um cara que cumprimenta, que é gentil, não que isso seja fundamental pra mim. (João)

Já peguei um Uber que não se comportava como motorista de carro particular, colocava som alto, não se preocupava com a temperatura do local (...), ficar conversando no celular enquanto dirige, digitando no WhatsApp. (Miguel)

Já aconteceu de chegar para mim o motorista com um carro diferente do cadastrado. Recusei e chamei outro. (Joaquim) 
Como eu só uso o cartão, eu sinto que eles burlam o sistema para ludibriar e tentar chegar a forma de pagamento que eu estou utilizando e com isso eles acabam cancelando a viagem (...) Eles mandam mensagens perguntando se o meu dinheiro está trocado, para quanto eu quero troco, e quando eu digo que o pagamento é em cartão e não precisarei de troco, aparece depois "seu motorista precisou cancelar a viagem". (Raquel)

O carro também ilustra a qualidade de forma negativa:

Não uso mais o Uber com frequência primeiro, porque os carros começaram a ficar muito sujos, os carros ficaram muito ruins e depois porque o Uber foi criando aquela fama ruim, e aí você foi tendo aquelas experiências... ah demora muito, o cara aceita depois ele cancela, porque se forem trajetos muito curtos. $O$ Uber é um que é mestre em cancelar porque eles querem pegar trajetos mais longos aí você fica ali tentando conseguir, perdendo um tempo. (Camila)

Com relação à conveniência, destacam-se aspectos associados à praticidade de poder pagar diretamente no aplicativo, sem a necessidade de portar dinheiro em espécie e à agilidade que a prática confere:

Porque o taxi eu preciso de dinheiro pra pagar (...) Eu não sei em quanto tempo vai chegar, eu não sei quem vem. (Raquel)

O Uber você pode pagar com cartão de crédito, paypal, não precisa ter dinheiro na mão que o taxi muitas vezes exigia (...) era muito mais rápido que o transporte público, em 20-30 minutos eu tava no centro e acabei pegando como maneira de facilitar o transporte (...) mas aonde é difícil estacionar (...), opto pelo aplicativo, acho que é mais prático (...) eu pego o Uber com a maior tranquilidade pra não ter dor de cabeça de estacionar, um dos principais problemas aqui na zona sul pra mim, particularmente, é estacionar. Não tem vaga. (Mateus)

Uso Uber fora do Rio de Janeiro (...) o Uber tem em todo lugar. A partir do momento que lançaram o primeiro aplicativo, eu já estava embarcando nele, porque queria me livrar do transporte de dinheiro vivo. Pagar com cartão de crédito, para mim, é uma enorme conveniência. (Lucas)

Uso quando preciso chegar mais cedo no trabalho, e quando saio da faculdade muito tarde, volto sempre de Uber. Comecei a usar o Uber porque é mais fácil, eu não preciso estar com dinheiro. (Carina)

O momento que eu comecei a usar foi principalmente por questão de agilidade, pegar no lugar que eu precisava numa hora específica e o transporte público não estava me atendendo, então eu migrava pra ele. (Mateus)

Outra perspectiva relativa à conveniência diz respeito às vantagens percebidas em relação ao transporte público, ao conforto oferecido e até mesmo em usar o carro particular, como demonstram os relatos das entrevistadas Joana, Luciana, Miguel e Rebeca:

O ônibus passava muito cedo, antes da aula acabar (...), pra gente poder compartilhar o preço e ir pra casa de Uber, a ainda deixava a gente na porta de casa e no ônibus a gente tinha que andar um pouco. (Joana) 
Se eu quisesse ir pro centro eu pegava um Uber em vez de ir de carro ou ir de ônibus porque estava muito calor... comecei usando assim pra coisas perto de casa. Hoje em dia eu uso bem mais. (Luciana)

Uso para locomoções em longas distâncias, em que é inviável o transporte público, por exemplo, quando vou da minha casa para a casa do meu pai, não passa ônibus na rua do meu pai, aí eu pego Uber (...) Semana passada choveu e eu tava num bar, aí eu fui pra casa de Uber, porque tava chovendo e em frente ao bar não é um lugar que passe meu ônibus, teria que andar até o ponto de ônibus, esperar, sem cobertura, aí eu peguei o Uber. Era mais cômodo. (Miguel)

Geralmente meus pais me levam até a porta, mas como eu tô voltando de madrugada, eles não me trazem, e eu peço um Uber pra voltar. (Rebeca)

Duas entrevistadas fizeram observações relacionadas à diversidade:

Teve uma vez que peguei um Uber com um moço que tinha deficiência auditiva, foi um pouco complicado, mas a gente conseguiu se comunicar direitinho (...) fico muito tranquila quando é uma motorista mulher. (Joana)

Eu tenho uma experiência positivíssima com um senhor que me deixou em casa uma vez. Ele começou a me contar como a própria Uber mudou a vida dele. Ele não tinha mais nenhuma perspectiva depois de aposentado e com o Uber ele conseguiu guardar algum dinheiro, além da aposentadoria dele, pra visitar os filhos, pra viajar com a esposa, mas pra isso ele precisava acordar por volta de 4 da manhã e largar por volta das 9 da noite. Mesmo ele trabalhando esse período inteiro, ele conseguia programar os períodos pra que ele obtivesse aquela renda pra que fizesse uma determinada viagem. A Uber estava fazendo com que ele conseguisse guardar esse dinheiro pra ter essas experiências que ele nunca teve durante toda a vida com a esposa, depois dos filhos já criados e adultos. O filho dele mora fora do país e ele com o Uber já conseguiu viajar pra visitar o filho no Canadá. (Hanna)

\subsubsection{2.}

\section{Níveis da narração e dos valores na manifestação serviço Uber $X$}

Por meio da análise das entrevistas, depreende-se que a narrativa global da manifestação Uber X é a Uber coloca o sujeito consumidor em conjunção com os valores segurança, confiança, custo-benefício, conveniência e diversidade.

Segundo a axiologia do consumo proposta por Floch (1993 p. 148), os valores identificados na manifestação Uber $\mathrm{X}$, estariam assim categorizados:

- Valorização prática: conveniência, confiança

- Valorização crítica: custo-benefício

- Valorização utópica: segurança, diversidade

- Valorização lúdica: não foram encontrados valores nessa categoria 


\subsubsection{2.}

\section{Manifestação Aplicativo}

\subsubsection{1. \\ Nível do discurso na manifestação Aplicativo}

$\mathrm{Na}$ manifestação Aplicativo, foram encontrados discursos relacionados ao funcionamento do aplicativo, à simplicidade, facilidade, confiança, tecnologia, conveniência.

Nos discursos relacionados à confiança, os entrevistados referiam-se tanto em relação ao funcionamento do aplicativo, como em relação às características do aplicativo em si, como ter o nome do motorista, a foto, a placa do carro, o preço da corrida, a duração do trajeto:

Tenho muita confiança no Uber, nunca tive grandes decepções com a empresa, e com o funcionamento do aplicativo. (Miguel)

Além de ter a confiança no aplicativo, de ser um aplicativo bom, importante ter o preço também, qualidade e preço que a gente busca. (Mateus)

Eu espero que o serviço do aplicativo seja cumprido, se eu contratei para ele ir do ponto $A B$ eu confio que eu vou lá no menor caminho possível (João)

O aplicativo é fácil e amigável. (Joaquim)

O aplicativo é bom, amigável, tranquilo, fácil de usar. (Raquel)

Eu acho muito autoexplicativo, não tem dificuldade não. (Hanna)

Uber pra mim e algo prático, ao alcance da minha mão, que não vai me trazer problema, que vai me levar e buscar com segurança e que não vai falhar comigo. (Luciana)

Eu confio mais ou menos no aplicativo. Tem a foto da pessoa, mas depois que você acaba a viagem, não tem como voltar na última viagem e saber quem fez, eu nunca tentei fazer isso. Então quando você pega, você tem logo que tirar um print, pra se caso aconteça alguma coisa com você, você já tem todos os dados da pessoa. (Joana)

Alguns entrevistados referiram-se a aspectos tecnológicos do aplicativo:

Nunca deu problema pra mim o aplicativo, eu nunca tive que excluir e baixar novamente como alguns aplicativos geralmente travam, o Uber nunca deu esse tipo de problema o aplicativo em si. (Carina)

É a questão de costume, de sempre tá pedindo o Uber, até porque Uber foi o aplicativo que foi lançado primeiro, e eu já tinha mais acesso, é uma plataforma mais fácil de usar. (Luciana)

Eu considero um aplicativo simples, ele é bem fácil de você encontrar as funcionalidades dele, também as opções de pagamento em dinheiro ou cartão são bem fáceis, você não precisa entender muito de tecnologia pra você mexer no aplicativo. (Rebeca) 
Luciana menciona aspectos relacionados à conveniência:

Uber pra mim e algo prático, ao alcance da minha mão. (Luciana)

Foram citados ainda alguns aspectos negativos em relação ao aplicativo:

Às vezes não consegue pedir carro, mas aí não é a questão da funcionalidade do aplicativo. (Carina)

Ás vezes o Uber duplica o meu pagamento, eu boto no cartão e vem duas vezes uma viagem só. (Rebeca)

O Uber tem muito disso de cancelar a corrida. Já aconteceu algumas vezes. Da pessoa olhar a corrida, eu ficar um tempo esperando, e o motorista cancelar. Ou demorar muito, parece que o motorista tá parado muito tempo, parece que é um forma pra eu cancelar. (Rebeca)

Alguns entrevistados foram específicos em relação a algumas funcionalidades do aplicativo, que ressaltam alguns dos aspectos já mencionados, como conveniência e confiança.

Baixei o aplicativo porque as minhas amigas disseram que poderíamos compartilhar o preço. (Joana)

Uber tem a possibilidade de ratear o valor com outra pessoa, mas eu nunca utilizei (Joaquim).

Eu posso acompanhar as viagens da minha filha. (Clara)

Quando estou voltando pra casa de madrugada, peço o aplicativo e posso mandar a corrida pros meus pais. (Rebeca)

Eles têm uma plataforma que você pode solicitar, falar que esqueceu um pertence, fiz isso e eles me devolveram, foi super tranquilo, no dia seguinte, bem rápido. (Rebeca)

\subsubsection{2.}

\section{Níveis da narração e dos valores na manifestação Aplicativo}

Segundo a axiologia do consumo proposta por Floch (1993 p. 148), identificou-se os valores conveniência e confiança como sendo os mais evidentes nessa manifestação, depreendendo-se como narrativa global: o aplicativo da Uber coloca o sujeito consumidor em conjunção com os valores confiança $e$ conveniência”. Tais valores estariam assim categorizados:

- Valorização prática: conveniência, confiança

- Valorização crítica: não foram encontrados valores nessa categoria

- Valorização utópica: não foram encontrados valores nessa categoria

- Valorização lúdica: não foram encontrados valores nessa categoria 


\subsubsection{3.}

\section{Manifestação Campanha Publicitária "Confiança começa com o nome"}

Foram apresentadas aos entrevistados cinco peças publicitárias que compunham a campanha publicitária "Confiança começa com o nome", veiculada a partir de maio de 2018. As peças foram apresentadas na seguinte ordem:

$$
\begin{aligned}
& 1 \text { - Filme versão 60" } \\
& 2 \text { - Anúncio "Júlia passageira 4.9" } \\
& 3 \text { - Anúncio "José está chegando agora" } \\
& 4 \text { - Anúncio "Confiança começa com o nome" } \\
& 5 \text { - Anúncio "Laura, Ana, Vera, Daniel" }
\end{aligned}
$$

\subsubsection{1. \\ Nível do discurso na manifestação Campanha Publicitária "Confiança começa com o nome"}

Após apresentação das peças publicitárias aos entrevistados, ficaram evidenciados discursos relativos à: confiança, segurança e proximidade. Alguns entrevistados associaram a confiança a outros atributos como qualidade, comodidade, bom preço:

A primeira coisa realmente é confiança e qualidade de atendimento (...) ० cara sabe o teu nome, esqueceu a mochila o cara pega aí a mochila. Quem é que faz isso né? Em taxi ou em transporte de maneira geral é difícil né. (Mateus)

A confiança vem da comodidade que a pessoa sente em pegar o Uber, em poder contar que você em qualquer lugar vai ter um motorista que vá poder te transportar, eles reafirmam que a confiança vem com a comodidade, com um bom preço. (Miguel)

É claro que eles forçam um pouquinho esse negócio do mundo perfeito e tal, mas é interessante a proposta, vamos dizer que, como a própria campanha diz é questão de confiança, que se tem qualidade tem confiança. (Mateus)

Essas pessoas aqui estão falando de confiança né... do Uber, mas eu vejo que hoje em dia é mais ou menos a mesma coisa, não vejo muita diferença entre o Uber e os outros (...) até porque a gente vê que eles usam todos os aplicativos, eles estão ali andando com você dentro do carro aí apita o negócio de outro aplicativo, então você sabe que é a mesma pessoa, eu não vejo tanta diferença assim do Uber não. (Luciana)

Você tem a confiança não só no aplicativo, de que ele vai funcionar, o carro vai chegar, no horário combinado, mas também de que usando o Uber, você vai estar numa viagem segura. (Carina) 
Outro tema identificado foi o da segurança, representado por algumas características e funcionalidades do aplicativo.

Essa possibilidade de acompanhar, de saber quando a pessoa tá chegando, dá segurança, que é possível acompanhar o trajeto todo. (Raquel)

Quando você pede Uber, você tem todos os dados dele, então isso transmite uma segurança maior. (Miguel)

Eu também mando a placa do Uber para a minha mãe. (Carina)

Sentimentos relacionados à segurança também foram evidenciados nos discursos dos entrevistados Joana, Mateus, João, Carina e Jonatan:

Quando tem mais gente você fica mais tranquilo, principalmente quando é um homem que tá no Uber. (Joana)

Talvez eles até, lançaram essa campanha pra desmistificar um pouco a questão do Uber ser perigoso que é o que começou a se espalhar muito com fake news e alguns fatos também que foi a questão do pessoal estar assaltando por meio de Uber, o assaltante chamava o Uber, ficava dentro do Uber ia pegando passageiro e assaltando, coisa e tal, então gerou um pouco de desconfiança das pessoas mais velhas que pegariam o Uber. (Mateus)

Se a ideia era transmitir segurança, talvez essa ideia de chamar pelo nome comece um movimento de fazer isso. (João)

Como eu nunca tive experiências ruins, eu sempre assimilo Uber com qualidade e com segurança principalmente pra mim. (Carina)

Eu enxergo de uma forma racional, eles estão divulgando que o produto deles é seguro e mais barato que o taxi, não sinto segurança nem falta de segurança, não é uma coisa que associe a imagem do Uber. (Jonatan)

Os entrevistados destacaram a proximidade que pode ser estabelecida entre motorista e passageiro. Tal proximidade é ilustrada pelo uso do nome na campanha:

O nome pra mim é importante porque se torna mais pessoal e eu acho que cria um vínculo maior (...) Eu olho a placa, eu olho o nome, porque eu sempre trato as pessoas pelo nome, não gosto de tratar de outra forma. (Carina)

Sempre vejo antes o nome dele, chamo ele pelo nome, ele me chama pelo nome também, acho isso legal, essa quebra de impessoalidade. (Mateus)

O nome do motorista é fundamental. (Raquel)

Geralmente eu não olho o nome do motorista, não vejo foto, não vejo nada. Só vejo a placa, pra identificar a placa. Só reparo o nome quando sobre na tela pra classificar o motorista. (Rebeca)

O nome para mim é importante porque eu vejo a foto, mas nunca falo o nome do motorista, isso é uma questão minha, não gosto de estabelecer esse contato, é uma questão de segurança pra mim. Eu não gosto quando eles querem puxar papo, eu acho que isso não tem relevância nenhuma. (Joana)

Eu sempre pergunto o nome quando entro no carro. (Miguel) 


\begin{abstract}
Acho que essa campanha é voltada pra pessoa comum pra tornar o ato do transporte uma coisa agradável, cordial, íntima... eu gosto muito que o aplicativo, qualquer que seja, tenha o nome do motorista e gosto da possibilidade de conversar, dialogar com o motorista. (Lucas)
\end{abstract}

Essa coisa do nome, eu tive a sensação que eles estavam dizendo "o cara do Uber é gente como a gente, uma coisa assim mais no sentido humanista, de humanizar a figura do cara que tá ali no carro, porque na prática mesmo você é transportado como carga, não é amizade, ele não é seu amigo. (João)

O Uber começou com um público de mais alto nível e executivos, inclusive só tinham aqueles carros de luxo, era serviço quase que exclusivo. As pessoas que pegavam o Uber se sentiam sofisticadas de usar o Uber (...) e eu tenho certeza que essa campanha não é pra esse tipo de pessoa, eu não vejo executivo ou a pessoa de alto padrão financeiro tendo a intenção de fazer uma amizade com o motorista do Uber. (Lucas)

Eu não vejo nenhum fator que o Uber traga nessa propaganda que o aplicativo de taxi não me dê também. Eu tenho ali, também, nome do motorista, eu tenho o tempo que ele vai chegar, eu posso me comunicar com ele por mensagem, eu posso compartilhar minha corrida pra outra pessoa acompanhar. Tudo isso qualquer aplicativo me oferece. (Lucas)

\title{
4.2.5.3.2. \\ Níveis da narração e dos valores na manifestação Campanha publicitária "Confiança começa com um nome"
}

Como narrativa global da campanha publicitária analisada, identifica-se: a Uber coloca o sujeito consumidor em conjunção com os valores proximidade, segurança e confiança.

Segundo a axiologia do consumo proposta por Floch (1993 p. 148), os valores identificados na manifestação Campanha publicitária "Confiança começa com o nome", estariam assim categorizados:

- Valorização prática: confiança

- Valorização crítica: não foram encontrados valores nessa categoria

- Valorização utópica: segurança, proximidade

- Valorização lúdica: não foram encontrados valores nessa categoria

\subsubsection{4. \\ Identidade manifesta da marca Uber}

Conforme observado nos tópicos anteriores, cada manifestação foi analisada em separado, conforme modelo representado na Figura 4, resultando nos dados da Tabela 7 . 


\begin{tabular}{|c|c|c|c|}
\hline & $\begin{array}{c}\text { Manifestação } 1 \\
\text { Uber X }\end{array}$ & $\begin{array}{c}\text { Manifestação } 2 \\
\text { Aplicativo }\end{array}$ & $\begin{array}{c}\text { Manifestação } 3 \\
\text { Campanha } \\
\text { Confiança começa } \\
\text { com o nome }\end{array}$ \\
\hline DISCURSO & $\begin{array}{l}\text { Mais barato que o táxi } \\
\text { Ótimo carro } \\
\text { Conforto do ar } \\
\text { condicionado } \\
\text { Motorista simpático, } \\
\text { solícito }\end{array}$ & $\begin{array}{l}\text { A foto, o nome, a } \\
\text { placa } \\
\text { Tecnologia }\end{array}$ & $\begin{array}{l}\text { A foto, os nomes, a } \\
\text { placa } \\
\text { Mulheres, negros, } \\
\text { idosa }\end{array}$ \\
\hline NARRAÇÃO & $\begin{array}{l}\text { É seguro, confiável } \\
\text { Não precisa ter } \\
\text { dinheiro } \\
\text { Tem em todo lugar } \\
\text { É mais barato }\end{array}$ & $\begin{array}{l}\text { Não dá problema } \\
\text { Fácil de usar }\end{array}$ & $\begin{array}{l}\text { É amigável } \\
\text { Eu confio } \\
\text { Me sinto seguro }\end{array}$ \\
\hline VALORES & $\begin{array}{l}\text { Segurança } \\
\text { Confiança } \\
\text { Conveniência } \\
\text { Custo-benefício } \\
\text { Diversidade }\end{array}$ & $\begin{array}{l}\text { Confiança } \\
\text { Conveniência }\end{array}$ & $\begin{array}{l}\text { Proximidade } \\
\text { Confiança } \\
\text { Segurança }\end{array}$ \\
\hline
\end{tabular}

Tabela 7: Análise das manifestações da marca Uber

Fonte: Elaboração própria. Adaptado de Semprini (2010, p. 160)

Cada uma das manifestações é considerada uma "micronarrativa de marca" e permite remontar uma parte de sua identidade, denominada identidade manifesta (SEMPRINI, 2010, p. 156).

A identidade manifesta da marca é composta pelo somatório das manifestações da marca. Foram identificados: o valor confiança nas três manifestações e os valores conveniência e segurança em duas das três manifestações analisadas, observando-se coerência entre as manifestações.

Os nomes do motorista e do usuário são características presentes nas manifestações Uber $X$ e Aplicativo. No entanto, não foram evidenciados nos discursos dos entrevistados acerca dessas manifestações. A Campanha publicitária, por sua vez, traz o nome como elemento tangível dos valores proximidade e confiança, tornando-o evidente.

O valor custo-benefício é visível apenas na manifestação Uber X e está relacionado à percepção do preço do serviço, em relação à qualidade. $\mathrm{Na}$ manifestação Uber $X$ identificou-se também o valor Diversidade. $O$ valor Proximidade ficou evidente na manifestação Campanha publicitária.

O valor inovação não foi identificado nos discursos dos entrevistados.

A identidade manifesta da marca Uber está representada na Figura 16. 


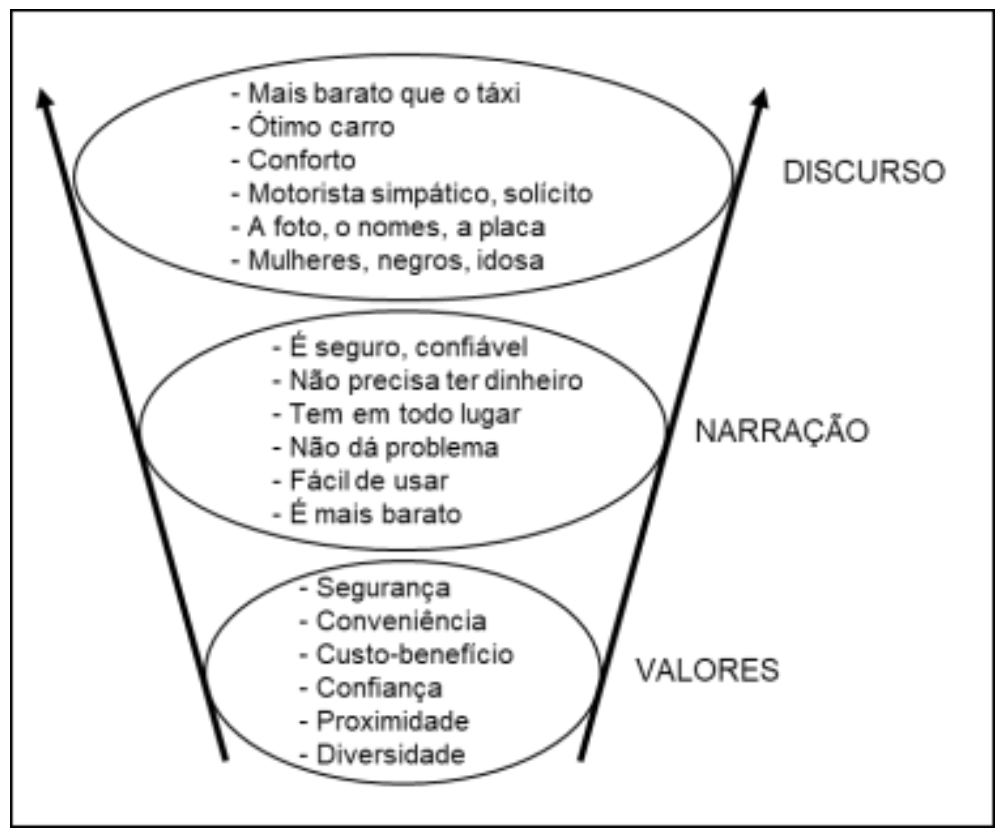

Figura 16: Identidade manifesta da marca Uber, obtida após análise das manifestações Fonte: Elaboração própria. Adaptado de Semprini (2010, p. 160)

Os tipos de valorização encontrados, de acordo com o modelo proposto por Floch (1993), estão indicados na Figura 17.

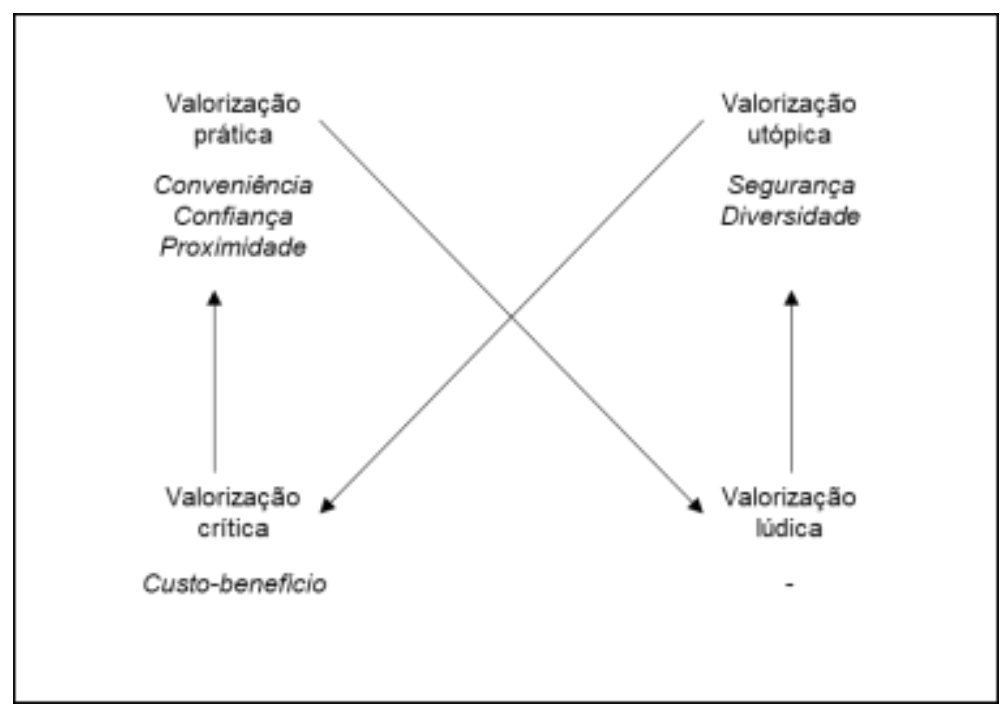

Figura 17: Tipos de valorização encontrados nas manifestações da marca Uber Fonte: Elaborado própria. Adaptado de Floch (1993, p. 148)

Os valores de uso são representados pela valorização prática. Na Uber esses valores seriam a conveniência, a confiança e proximidade. Em oposição, estaria a valorização lúdica. No entanto, não foram identificados indícios desse tipo de valorização nos discursos dos entrevistados.

A valorização utópica estaria representada por valores de base. $\mathrm{Na}$ Uber, foram evidenciados a segurança e a diversidade. Em oposição, estaria o valor crítico, custo-benefício. 


\subsection{6.}

\section{Aproximações e afastamentos entre o projeto de marca Uber e a identidade manifesta}

Conforme apresentado no tópico 4.2.4, o projeto da marca Uber pode ser resumido da seguinte forma: ser uma marca segura e confiável, que cria oportunidades para todos (diversidade), oferecendo conveniência, através de viagens com qualidade, facilitadas pela tecnologia (inovação).

A Figura 18 apresenta, de forma esquemática, os valores encontrados no projeto de marca recomposto e nas manifestações da marca, a identidade manifesta.

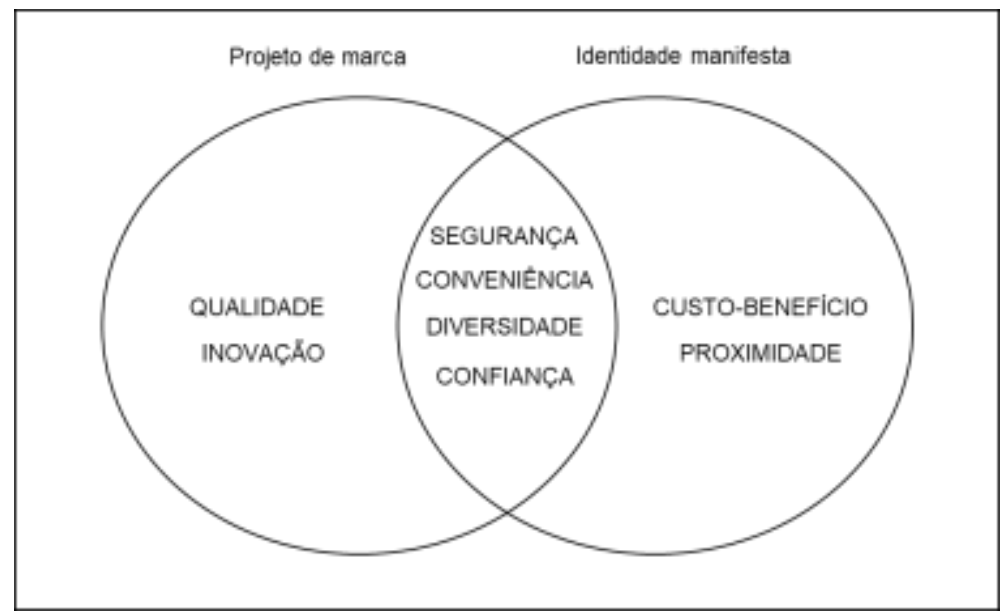

Figura 18: Valores encontrados no projeto da marca e na identidade manifesta da marca Uber Fonte: Elaboração própria. Adaptado de Floch (1993)

Os adjetivos segura e confiável presentes no projeto são encontrados na identidade manifesta, através da análise das três manifestações, nas quais ficam evidentes os valores segurança e confiança, sendo este último presente nos discursos acerca das três manifestações. Embora tenham se referido à segurança, alguns entrevistados, especialmente do sexo feminino, fizeram alusões à ausência de segurança, quando se referiram a situações de medo ou vulnerabilidade.

O valor confiança é o título da campanha publicitária analisada, sendo componente do projeto de marca. A materialização da confiança através do nome pode ter sido um recurso da marca para, através da campanha publicitária, aumentar a segurança em relação aos serviços, mitigando aspectos de falta de confiança. A campanha sugere que, através de uma relação mais próxima e amigável, há a possibilidade de se obter maior segurança e confiança.

O mesmo parece ocorrer com o valor proximidade, presente no discurso dos consumidores acerca da manifestação Campanha publicitária "Confiança 
começa com o nome". Tal valor não está saliente no projeto da marca e sua evidência pode ter sido consequência da mensagem da campanha.

A conveniência de poder pedir o carro, em qualquer lugar, de forma rápida e fácil e da forma como surge na identidade manifesta, enquadra-se como um valor de uso, já que traz aspectos meramente funcionais.

O valor inovação, representado pela tecnologia, é ressaltado apenas no projeto da marca, quando se apresenta como: "A Uber é uma empresa de tecnologia e não de transporte". Os consumidores discordam da afirmação e entendem que a marca é uma marca de transporte. Esse afastamento pode estar relacionado ao tipo de serviço ofertado e à concorrência estabelecida (taxis, transporte público).

O valor custo-benefício, presente na identidade manifesta, não é um valor totalmente saliente no projeto recomposto. O projeto da marca fala de qualidade que está relacionada ao benefício apontado pelos entrevistados já que a qualidade também está presente em seus discursos. No entanto, o projeto da marca não faz menção ao preço dos serviços.

O valor diversidade, componente do projeto de marca, encontra baixa ressonância entre os consumidores, sugerindo que a marca deva reforçar essas evidências nas manifestações.

\subsection{7. \\ Relação entre o projeto de marca Uber, a identidade manifesta e os conceitos de consumo colaborativo}

Dos conceitos encontrados com frequência na literatura pesquisada acerca do tema consumo colaborativo, apenas o conceito confiança foi encontrado como valor presente tanto no projeto reconstituído da marca Uber como na identidade manifesta. O conceito inovação é detectado no projeto de marca, mas não é observado na identidade manifesta. Parte dos consumidores entrevistados discorda que a Uber seja uma "empresa de tecnologia".

Os demais conceitos presentes no consumo colaborativo encontrados na literatura pesquisada como comunidade, engajamento, não propriedade e reciprocidade não foram observados no projeto recomposto e na identidade manifesta da marca Uber (Figura 19). 


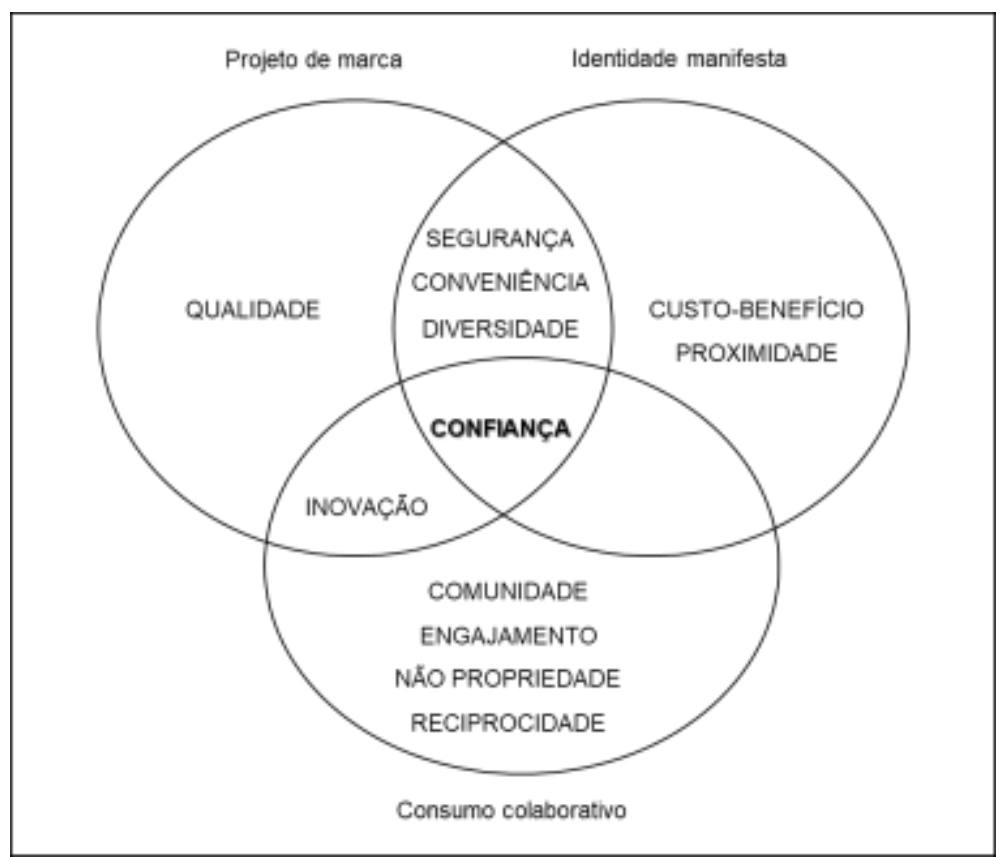

Figura 19: Conceitos encontrados na literatura sobre consumo colaborativo presentes no projeto e na identidade manifesta da marca Uber

Fonte: Elaboração própria

\section{3. \\ Discussão}

Ao explorar o significado de consumo colaborativo no discurso dos consumidores, foram encontrados entendimentos diversos, do mesmo modo que se observou na literatura pesquisada. Uma parte dos entrevistados possui uma visão utópica sobre a prática, associando a modalidade à vida em comunidade, à cooperação, ao dar e receber sem necessariamente esperar algo em troca, a momentos prazerosos, à atitudes positivas como dar carona, receber amigos em casa, doar livros para bibliotecas comunitárias, ofertar seu tempo livre para uma atividade coletiva.

Uma das entrevistadas demonstrou, em seu relato, o prazer que a prática de hospedar pessoas em sua casa pela plataforma Airbnb Ihe conferia. Embora existisse compensação, já que o hóspede estava pagando pela hospedagem, não foram citados aspectos financeiros, apenas aspectos relacionados ao convívio social, como se sentir bem ao conversar com o hóspede e receber presentes, podendo se depreender que, atualmente, o hóspede espera um serviço semelhante ao de um hotel, com menos proximidade, caracterizando uma relação mercantil.

Alguns entrevistados trataram do aproveitamento de recursos, da possibilidade de oportunizar o uso de um bem que estaria ocioso, através do 
consumo colaborativo. Nenhuma menção foi feita aos benefícios ambientais que tal prática poderia acarretar e, nem tampouco, em relação ao comportamento de compra, ou seja, de que o consumo colaborativo os levaria a comprar menos.

Uma outra parcela de entrevistados percebe que o consumo colaborativo é uma modalidade de troca, de compra e venda, que deve prever pagamento.

A maioria dos entrevistados sugere baixa disposição para o consumo colaborativo entre estranhos. Aspectos relacionados à segurança ou à sua ausência, bem como o desejo de preservar a individualidade, podem ser razões para tal. O mesmo não se observa quando a prática de consumo não envolve contato físico, como é o caso dos conteúdos compartilhados mediados pela tecnologia, como músicas, filmes, livros, opiniões.

Já o compartilhamento familiar é tratado como habitual, o que não significa que é sempre positivo, já que alguns compartilham por necessidade, como é caso da entrevistada que considera ser ruim o fato de precisar compartilhar o carro com pai.

Ao indicar a disposição para o consumo colaborativo, os entrevistados mais jovens sugeriram ter maior intenção em fazê-lo, mesmo com estranhos. Entretanto, ao serem questionados sobre a utilização do serviço Uber Juntos, alguns deles demonstraram reações negativas, reforçando a contradição que foi apontada por Lindblom e Lindblom (2017), sinalizando que tal disposição pode variar de acordo com o objeto que será compartilhado.

A experiência na utilização dos serviços da Uber reflete, para alguns entrevistados, uma prática de consumo colaborativo havendo, inclusive, a citação do benefício ambiental por um deles que entende estar contribuindo para o meio ambiente, ao deixar de usar seu carro. Outro fator associado ao consumo colaborativo, por esse mesmo entrevistado e por outros, é a renda que o motorista obtém ao colocar seu carro a serviço de terceiros, entendendo que a modalidade deve prever compensação monetária (BOTSMAN; ROGERS, 2010).

Entre os entrevistados que não consideram tal experiência como consumo colaborativo, as justificativas são de que estão comprando, pagando por um serviço. Contudo, mesmo entre eles, são destacados em alguns relatos, aspectos presentes no consumo colaborativo, como no da entrevistada que alega se sentir mais segura porque o motorista-parceiro usa o mesmo carro para suas atividades, sugerindo o aproveitamento do recurso, no de outro, que diz se sentir "fazendo parte de uma tribo", e ainda, no do entrevistado que percebe o motorista da Uber como "um amigo". Tais demonstrações sugerem evidências associadas aos conceitos de consumo colaborativo presentes na literatura. 
Dentre os motivos para utilização do serviço prestado pela Uber, destaca-se a redução de riscos e responsabilidades, o que pode ser atribuído a alguns fatores: à carência do transporte público brasileiro, à dificuldade de se estacionar nas grandes cidades, à faixa etária da maioria dos entrevistados ser inferior a 35 anos, demonstrando que as gerações mais jovens não consideram mais o carro como símbolo de status, e sim como um meio de transporte (PwC, 2015).

$\mathrm{Na}$ sequência, os motivos econômicos foram os mais alegados, seguidos dos motivos sociais. Alguns entrevistados narraram que, antes da decisão acerca de qual marca escolher, entre Uber, 99 e Cabify, comparam os preços, utilizando um aplicativo para isso, e optam pelo mais barato, por não perceberem diferença em relação ao serviço entregue pela Uber. No entanto, a maioria dos entrevistados destaca a vantagem de preço da Uber em relação ao táxi.

Entre os sentimentos em relação às experiências na Uber, foram citados aspectos positivos e o termo "tranquilidade" e a expressão "sem estresse" ilustraram alguns relatos. Os sentimentos negativos descritos foram relacionados à insegurança, às posturas inadequadas de motoristas e à vulnerabilidade, especialmente feminina.

A vulnerabilidade feminina surgiu como um tema recorrente nos relatos das entrevistadas e um dos entrevistados sugeriu que, por ser homem, se sentia mais seguro, o que talvez não acontecesse se fosse mulher. Outras entrevistadas alegaram medo e desconforto por estarem sendo conduzidas por um homem e uma das entrevistadas demonstrou uma reação acentuada, ao afirmar que "todo homem pode ser um estuprador em potencial".

Fundada há apenas dez anos, a marca Uber possui amplo portfólio de produtos que pode ser adaptado a cada região de atuação. Embora se apresente como uma empresa de tecnologia, a Uber oferta serviços tradicionais, como o de transporte de passageiros ou delivery de pratos prontos. Seu caráter inovador consiste na forma como provê tais serviços, através da tecnologia. Embora seja considerada pela grande mídia e pela literatura acadêmica, como uma das protagonistas do consumo colaborativo, e ser identificada por alguns consumidores entrevistados neste estudo como tal, pelas evidências aqui analisadas, a marca Uber não tenta se posicionar dessa forma.

A utilização do valor confiança na campanha publicitária veiculada em 2018 pode sugerir uma aproximação a esse contexto, já que explora um conceito chave para o consumo colaborativo (BOTSMAN; ROGERS, 2010). Entretanto, os recursos para construção de confiança utilizados pela Uber em seu discurso geram, para uma parte dos entrevistados, uma sensação de insegurança, já que 
alguns relataram situações de medo e de vulnerabilidade. O valor confiança esteve mais associado às funcionalidades do produto e à eficiência global do serviço. Pode ser notada, portanto, uma dissonância entre o projeto de marca e a identidade manifesta, no que tange ao valor confiança.

O valor custo-benefício, por sua vez, presente na identidade manifesta, sugere indicar uma fragilidade para a marca, levando-a a buscar a competição por preços. Como o consumidor não percebe a diferença e não identifica que a qualidade dos serviços da Uber seja superior aos das marcas concorrentes, opta pelo mais barato. Uma maneira de buscar a diferenciação poderia ser através da utilização de outros conceitos do consumo colaborativo como o de comunidade e o de engajamento, transformando-os em valores da marca.

O conceito de comunidade aparece, de forma sutil, em alguns relatos, como no do entrevistado, que se sente "fazendo parte de uma tribo" ao utilizar a Uber. Já o conceito de engajamento pode ser reforçado através da tecnologia, da presença e interação da marca nas redes sociais. $O$ valor diversidade, identificado na identidade manifesta, pode ajudar a reforçar esse conceito, à medida que cria nos consumidores um senso de pertencimento, de inclusão.

O potencial transformador da empresa também pode ser evidenciado nas manifestações da marca, para que seja percebido e valorizado pelos consumidores. O relato de uma das entrevistadas sobre um motorista-parceiro, já aposentado, que através da Uber conseguiu renda para viajar, proporcionando experiências que ele nunca havia tido, é um exemplo disso. 


\section{5 \\ Considerações finais}

O presente estudo teve como objetivo explorar os significados do consumo colaborativo para os consumidores e explicitar as aproximações e afastamentos entre o projeto de marca proposto pela Uber e as interpretações das manifestações dessa marca pelos consumidores, a partir da aplicação do modelo Projeto/Manifestações de marca (SEMPRINI, 2010). A utilização do escopo teórico metodológico da semiótica discursiva de linha francesa na análise do projeto da marca ressalta o seu caráter inovador.

Para cumprir o objetivo proposto, foi empregada a perspectiva qualitativointerpretativa, em que as unidades de análise foram os discursos dos consumidores e da marca Uber. A investigação das percepções dos consumidores acerca do tema consumo colaborativo e das manifestações da marca Uber, deuse através da realização de quinze entrevistas, durante os meses de outubro de 2018 a janeiro de 2019.

Os achados da pesquisa indicam que o significado de consumo colaborativo diverge entre os consumidores pesquisados já que parte deles entende que é uma relação sem compensação alguma, e outros entendem que a modalidade deve prever pagamento. Há ainda os que associam a prática ao aproveitamento de recursos e uma forma de acesso a bens e serviços.

Alguns dos consumidores entrevistados demonstraram baixa disposição para o consumo colaborativo entre estranhos e, surgiram incômodos até mesmo no compartilhamento de alguns bens como carro e computador entre membros da mesma família.

Embora a marca Uber não tente se posicionar como uma marca de consumo colaborativo, já que se apresenta como uma "empresa de tecnologia", as experiências vividas no contato com a marca configuram e tangibilizam, para alguns consumidores, o significado de consumo colaborativo, justificando assim a ampliação do problema de pesquisa deste estudo.

A escolha do valor Confiança na primeira campanha veiculada no Brasil para posicionar a marca Uber junto ao público sugere uma tentativa de aproximação ao contexto de consumo colaborativo, já que se trata de um conceito-chave da modalidade. Há, no entanto, dissonância nesse valor, quando se compara o 
projeto recomposto ao projeto manifesto, já que os consumidores entrevistados associaram o termo à aspectos práticos e funcionais do aplicativo e do serviço, o que não significa, necessariamente, confiança na marca.

Outra dissonância surge ao se analisar os achados aqui produzidos com a promessa do consumo colaborativo, que é estabelecer uma forma de consumo, mais inclusiva, viável, consciente e responsável, já que não foram encontradas alusões nesse sentido, no discurso da maioria dos consumidores entrevistados. Pelo contrário, ao serem indagados se utilizavam a modalidade Uber Juntos, criada com esse objetivo, afirmaram não o fazer por não se sentirem seguros em compartilhar o serviço com estranhos, mesmo pagando menos.

Algumas aplicações gerenciais podem ser daqui depreendidas e dizem respeito ao aperfeiçoamento do projeto da marca Uber através de suas manifestações. Uma sugestão seria para a marca utilizar elementos que aprimorassem a assimilação de alguns valores pelo público: melhorar a percepção de qualidade no serviço, otimizando assim a relação custo-benefício; atenuar a dissonância que existe no valor confiança, reforçando o valor segurança; apropriar-se de outros conceitos do consumo colaborativo como comunidade e engajamento, além de estimular o valor diversidade, evidenciando elementos de transformação na vida dos motoristas-parceiros e consumidores.

A partir dos resultados do estudo, são feitas algumas propostas para pesquisas futuras. A primeira delas seria a complementação desta pesquisa, inserindo os discursos dos motoristas-parceiros da Uber como unidade de análise. Outra proposta seria a ampliação da análise, considerando um maior número de manifestações da marca Uber, como o logo, as páginas de redes sociais e outras campanhas publicitárias, associada ao entendimento do projeto da marca, através de entrevistas com executivos da empresa e da agência de publicidade que detém a conta da marca. Um terceiro caminho seria o de explorar outras marcas do consumo colaborativo, a fim de identificar até que ponto os seus projetos estão fazendo sentido para o seu público-alvo e se existem elementos comuns entre os projetos das marcas inseridas nessa modalidade de consumo. Sugere-se ainda a realização de pesquisas quantitativas para identificar atributos e valores presentes nos projetos das marcas de consumo colaborativo. 


\section{6 \\ Referências Bibliográficas}

AAKER, D. Brand Equity: Gerenciando o valor da marca. Tradução de André Andrade. 14. ed. São Paulo: Elsevier. Título original: Managing brand equity, 1998.

AIRBNB. Página oficial. Disponível em: https://www.airbnb.com.br/. Acesso em: 15 jul. 2018.

ALBINSSON, P.; PERERA, Y. Alternative marketplaces in the 21st century: Building community through sharing events. Journal of Consumer Behavior, vol. 11, p. 303-315, 2012.

ARCIDIACONO, D., GANDINI, A. Sharing what? The "sharing economy" in the sociological debate. The Sociological review. Sage Journals. v. 66, n. 2, p. 275288, 2018.

BARDIN, L. Análise de conteúdo. Lisboa: 70 ed., 1977.

BARDHI, F.; ECKHARDT, G. Access-based consumption: the case of car sharing. Journal of Consumer Research. v. 39, n. 4, p. 881-898, 2012.

BARNES, S.; MATTSSON, J. Building tribal communities in the collaborative economy: an innovation framework. Prometheus, v. 34, n. 2, p. 95-113, 2016.

BARNES, S.; MATTSSON, J. Understanding collaborative consumption: Test of a theoretical model. Technological Forecasting \& Social Change, v. 118, p. 281-292, 2017.

BARROS, D. Estudos do discurso. In: FIORIN, J.L. (org.). Introdução à linguística II: princípios de análise. 4. ed. São Paulo: Contexto, 2005.

BARROS, D. Teoria semiótica do texto. São Paulo: Ática, 2008.

BELK, R. Why not share rather than own? The Annals of the American Academy of Political and Social Science, v. 611, n. 1, p. 126-140, 2007.

BELK, R. Sharing. Journal of Consumer Research. v. 36, p. 715-734, 2010.

BELK, R. You are what you can access: Sharing and collaborative consumption online. Journal of Business Research, 67(8), 1595-1600. https://doi.org/10.1016/i.jbusres.2013.10.001, 2014.

BENOIT, S., BAKER, T., BOLTON, R., GRUBER, T.; KANDAMPULLY, J. A triadic framework for collaborative consumption (CC): Motives, activities and resources \& capabilities of actors. Journal of Business Research, 79 (November 2016), 219227. https://doi.org/10.1016/j.jbusres.2017.05.004, 2017. 
BHARDWAJ, P. The 26 most valuable private tech companies in the world. Site Business Insider.com, 15 mai. 2018. Disponível em: < https://www.businessinsider.com/most-valuable-private-tech-companies-in-theworld-list-pitchbook-2018-5 >. Accesso em: 12 out. 2018.

BOTSMAN, R.; ROGERS, R. What's mine is yours. The rise of collaborative consumption. New York, HarperCollins, 2010.

BRANDÃO, R. Compartilhar é a tendência do futuro. O Estado de São Paulo, São Paulo, 07 abr. 2017. Disponível em: $<$ http://economia.estadao.com.br/noticias/geral,compartilhar-e-a-tendencia-dofuturo,70001729705>. Acesso em: 16 dez. 2017.

CATALDI, A. A Uber recebeu US\$ 7 bilhões da Softbank, mas saiu perdendo. Site Globo.com, Rio de Janeiro, 29 dez, 2017. Disponível em: $<$ https://revistaautoesporte.globo.com/Noticias/noticia/2017/12/uber-recebeu-us7-bilhoes-da-softbank-mas-saiu-perdendo.html>. Acesso em: 24 out. 2018.

CÓCOLO, V. Professores aposentados da Unicamp criam proposta de moradia coletiva para envelhecerem juntos: 'Autonomia'. Site Globo.com, Campinas, 03 abr, 2018. Disponível em: <https://g1.globo.com/sp/campinasregiao/noticia/professores-aposentados-da-unicamp-criam-proposta-de-moradiacoletiva-para-envelhecerem-juntos-autonomia.ghtml> Acesso em: 24 fev. 2019.

COLLABORATIVE FUND. Disponível em: <http://collaborativefund.com/>. Acesso em: 12 out. 2018.

CONSUMO COLABORATIVO. Guia Consumo colaborativo e Economia compartilhada. São Paulo, 2017. Disponível em: < http://consumocolaborativo.cc/>. Acesso em: 16 jul. 18.

COUCHSURFING. Página oficial. Disponível em: https://www.couchsurfing.com/. Acesso em: 15 jul. 2018.

CRUZ, E. P. Consumo colaborativo cresce e $40 \%$ das pessoas trocam hotel por casa de terceiros. Site Agência Brasil, São Paulo, 10 ago, 2017. Disponível em: http://agenciabrasil.ebc.com.br/economia/noticia/2017-08/consumo-colaborativocresce-e-40-das-pessoas-trocam-hotel-por-casa-de. Acesso em: 25 mar. 2019.

FELSON, M., SPAETH, J. Community structure and collaborative consumption. A Routine activity approach. The American Behavioral Scientist, 21(4): 614-624, 1978.

FIORIN, J.L. Elementos de análise do discurso. 15. ed., São Paulo. Ed Contexto, 2016.

FLOCH, J. M. Semiótica, marketing y comunicación. Bajo los signos, las estratégias. 1. ed. Barcelona. Ediciones Paidos, 1993.

FLOCH, J. M. Documentos de estudo do Centro de Pesquisas Sociossemióticas. Tradução de Analice Dutra Pilar. Revisão Ana Claudia de Oliveira e Eric Landowski. São Paulo: Centro de Pesquisas Sociossemióticas. Título original: Quelques concepts fondamentaux em sémiotique génerale, In: Petites mythologies de l'oeil et de l'espirit, 2001.

GREIMAS, A., COURTÉS, J. Dicionário de Semiótica. São Paulo: Contexto, 2008. 
HOFFMAN, L.; BENSINGER, G.; FARRELL, M. Uber Proposals Value Company at $\$ 120$ Billion in a Possible IPO. Disponível em: $<$ https://www.wsi.com/articles/uber-proposals-value-company-at-120-billion-in-apossible-ipo-1539690343>. Acesso em: 02 fev. 2019.

JOHN, N. Sharing, collaborative consumption and Web 2.0. Media@LSE Eletronic Working Papers, n. 26, 2012.

KOTLER, P., KELLER, K. Administração de marketing. 12. Ed. São Paulo: Prentice Hall, 2011.

KUSISTO, L. Tiny Rooms, Shared Kitchens: Co-Living on the Rise in Big Cities. The Wall Street Journal, New York, 16 out. 2018. Disponível em: $<$ https://www.wsj.com/articles/co-living-buildings-going-big-in-brooklyn-and-bayarea-1539687600>, 2018.

LEVY, B. Compartilhamento como prática de consumo em famílias urbanas de classe média baixa. Um estudo interpretativo. 2015. Tese (Doutorado em Administração de Empresas) - Departamento de Administração, Pontifícia Universidade Católica do Rio de Janeiro, Rio de Janeiro, 2015.

LINDBLOM, A.; LINDBLOM, T. De-ownership orientation and collaborative consumption during turbulent economic times. International Journal of Consumer Studies, v. 41, p. 431-438, 2017.

MALHOTRA, N. Pesquisa de Marketing: uma orientação aplicada. Tradução de Laura Bocco. 4. ed. Porto Alegre. Bookman. Título original: Marketing Research: An applied orientation, 4. ed, 2004.

MCMILLAN, D. Uber in Fresh Funding Round That Could Value Company at Up to \$64.6 Billion. The Wall Street Journal, New York, 03 dez. 2015. Disponível em: $<$ https://www.wsi.com/articles/uber-in-fresh-funding-round-that-could-valuecompany-at-up-to-64-6-billion-1449180409>. Acesso em: 24 out. 2018.

MELO, C. Uber. A história da startup mais valiosa do mundo. Site Administradores.com. São Paulo, 04 ago. 2015. Disponível em: $<$ http://www.administradores.com.br/artigos/empreendedorismo/uber-a-historiada-startup-mais-valiosa-do-mundo/89284/>. Acesso em: 26 out. 2018.

MELO, L. Após aporte de US\$2,1 bi, Uber já vale mais que Ford ou GM. Site Exame.com, São Paulo, 01 jun. 2016. Disponível em: $<$ https://exame.abril.com.br/negocios/com-aporte-de-us-2-1-bi-uber-ja-vale-maisque-ford-ou-gm/>. Acesso em: 26 out. 2018.

MICK, D. Consumer research and semiotics. Exploring the morphology of signs symbols, and significance. Journal of Consumer Research. v. 13. N. 2. P. 196-213, 1986.

MITTENDORF, C. The Implications of Trust in the Sharing Economy - An Empirical Analysis of Uber, Proceedings of the 50th Hawaii International Conference on System Sciences. 5837-5846, 2017.

MÖHLMANN, M. Collaborative consumption: determinants of satisfaction and the likelihood of using a sharing economy option again, Journal of Consumer Behavior. n. 14. p. 193-207, 2015. 
OUISHARE. Disponível em: <https://ouishare.net/>. Acesso em 12 out. 2018.

PESSÔA, L. A. Narrativas de segurança no discurso publicitário: um estudo semiótico. São Paulo: Mackenzie, 2013.

PESSÔA, L. A. As marcas subjetivadas. In: OLIVEIRA, A.C.; MARTINIUK, V.L. (org.) Sentidos de consumo: os desafios do cenário contemporâneo à luz da semiótica de Greimas. 1 ed. São Paulo: Estação das Letras e Cores, 88-107, 2017.

PESSÔA, L. A., SANT'ANA, V., MELLO, F. Reflexões sobre as perspectivas de contribuição da semiótica francesa para os estudos de marketing e branding. RIMAR. Revista Interdisciplinar de Marketing. v. 5, n. 2, p. 69-81, 2015.

PISCICELLI, L.; COOPER, T.; FISHER, T. The role of values in collaborative consumption: insights from a product-service system for lending and borrowing in the UK. Journal of Cleaner Production, v. 97, p. 21-29, 2015.

PRICEWATERHOUSE COOPERS. Sharing or paring. Growth of the sharing economy. 17th Annual Global CEO Survey. UK Executive Summary. London, 2015.Disponível em: <https://www.pwc.com/hu/en/kiadvanyok/assets/pdf/sharingeconomy-en.pdf>. Acesso em 15 out. 2017.

SEMPRINI, A. A marca pós-moderna: poder e fragilidade da marca na sociedade contemporânea. Tradução de Elisabeth Leone. 2. Ed. São Paulo: Estação das Letras e Cores, 2010.

SHERRY JR., J. Significado da marca p. 40-69. In: Branding. TYBOUT, A., CALKINS, T. (org). São Paulo, Atlas, 2006.

SLEE, T. What's your's is mine. Against the sharing economy. London: OR Books/Counterpoint, 2017.

SOLITTO, A. Uma geração sem carro. Revista Isto é. São Paulo, 21. Set. 2018. Disponível em: <https://istoe.com.br/uma-geracao-sem-carro/>. Acesso em: 25 mar. 2019.

SUNDARARAJAN, A. The sharing economy. The end of employment and the rise of crowd-based capitalism. Cambridge. The MIT Press, 2016.

TEM AÇUCAR? Disponível em: <http://www.temacucar.com/>. Acesso em: 12 out. 2018.

UBER. Disponível em: <https://www.uber.com/pt-BR/about/>. Acesso em: 28 set. 2018.

VAQUERO, A.; CALLE, P. The collaborative consumption: A form of consumption adapted to modern times. Revista de Estudios Económicos y Empresariales. $\mathrm{n}$. 25 , p. 15-30, 2013.

VERGARA, S. Métodos de coleta de dados no campo. São Paulo. Editora Atlas, 2009.

WALSH, B. Today's smart choice: don't own. Share. Time Magazine. 17 mar. 2011. Disponível

em: <http://content.time.com/time/specials/packages/article/0,28804,2059521_20597 17,00.html>. Acesso em: 16 dez. 2017. 


\section{Anexos}

\section{1.}

\section{Formulário para preenchimento eletrônico}

Esta é uma pesquisa acadêmica para o desenvolvimento de uma dissertação para o Mestrado Acadêmico em Administração/Marketing da PUC Rio cujo objetivo é investigar a utilização de serviços através de aplicativos tecnológicos entre consumidores brasileiros.

A intenção é selecionar candidatos para participar de uma entrevista presencial durante o mês de outubro/18.

As respostas a essa pesquisa são de uso estritamente acadêmico.

Você já utilizou ou utiliza aplicativos (apps) em dispositivos móveis (smartphones) ou computadores pessoais?

( ) $\operatorname{Sim}$ ( ) Não

Quais dos aplicativos abaixo você utiliza ou já utilizou? (Assinalar uma ou mais opções)
( ) Hospedagem (Airbnb, Couchsurfing, outros)
( ) Transportes (Uber, 99, Cabify, TemBici, outros)
( ) Caronas (Waze Carpool, Turbi, Bynd, outros)
( ) Compras (OLX, eBay)
( ) Outros. Especifique

Marque quais serviços você utilizou na última semana:
( ) Hospedagem (Airbnb, Couchsurfing, outros)
( ) Transportes (Uber, 99, Cabify, TemBici, outros)
( ) Caronas (Waze Carpool, Turbi, Bynd, outros)
( ) Compras (OLX, eBay)
( ) Outros. Especifique

Marque quais serviços você utilizou no último mês:
( ) Hospedagem (Airbnb, Couchsurfing, outros)
( ) Transportes (Uber, 99, Cabify, TemBici, outros)
( ) Caronas (Waze Carpool, Turbi, Bynd, outros)
( ) Compras (OLX, eBay)
( ) Outros. Especifique

Marque quais serviços você utilizou no último ano:

( ) Hospedagem (Airbnb, Couchsurfing, outros)

( ) Transportes (Uber, 99, Cabify, TemBici, outros)

( ) Caronas (Waze Carpool, Turbi, Bynd, outros)

( ) Compras (OLX, eBay)

( ) Outros. Especifique 
Você aceita participar de uma entrevista em data e horário a combinar? ( ) Sim ( ) Não

Por favor, preencha os campos abaixo com seus dados e enviaremos detalhes sobre a entrevista.

Nome:

Idade: ( ) 20 a 30 anos ( ) 30 a 40 anos ( ) acima de 40 anos

Escolaridade: ( ) Superior completo/incompleto ( ) Pós graduação

( ) Mestrado/Doutorado

Telefone: e-mail:

Prefiro receber informações por ( ) WhatsApp ( ) e-mail ( ) Ambos

Obrigada pela participação! 


\section{2.}

\section{Roteiro de entrevista}

Agradecimento, informar o objetivo do trabalho: Investigar o uso dos aplicativos digitais, como por exemplo Uber, Airbnb, Couchsurfing.

Com base no questionário que você preencheu, observei que você usa os aplicativos para transporte e viagens. Quais você utiliza?

Qual o tipo de suporte - smartphone, PC? Se for no Smartphone.

Observei também que você utilizou o aplicativo de transporte na última semana, ou o de viagens no último ano ou recente.

\section{Etapa 1 - Transportes}

$\checkmark$ Por que você começou a usar o app? Já conhecia, foi indicação?

$\checkmark$ Quais os critérios para escolher usar o aplicativo

$\checkmark$ Em que situações você utiliza, para que tipo de trajeto

$\checkmark$ Você utiliza sozinho ou acompanhado?

$\checkmark$ Me conta algumas experiências recentes

$\checkmark$ Você viu essa campanha publicitária ou textos do site?

$\checkmark$ Com base na sua experiência na utilização do app, qual a sua percepção sobre essa campanha?

\section{Etapa 2 - Hospedagem}

$\checkmark$ Por que você começou a usar o app? Já conhecia, foi indicação?

$\checkmark$ Quais os critérios para escolher usar o aplicativo

$\checkmark$ Em que situação você utilizou pela última vez?

$\checkmark$ Que critérios você utilizou para escolher o apartamento?

$\checkmark$ A decisão foi sua ou envolveu mais alguém?

$\checkmark$ Me conta sua última experiência de viagem onde você utilizou.

\section{Etapa 3 - Consumo Colaborativo}

$\checkmark$ Agora, quero contextualizar uma situação. Quando você era pequeno, você tinha o hábito de compartilhar alguma coisa em sua casa?

$\checkmark$ Algum produto, em específico?

$\checkmark$ E hoje, você tem o hábito de compartilhar?

$\checkmark$ Você entende que o que o Uber ou AirBnb fazem podem ser consideradas modalidades de consumo colaborativo ou compartilhamento?

$\checkmark$ Por que? 


\section{3}

\section{Termo de Livre Consentimento}

Agradecemos a sua participação nesta entrevista, conduzida por Leila Toledo Martinho (mestranda de Administração de Empresas na Pontifícia Universidade Católica do Rio de Janeiro), que pode ser encontrada no telefone: (21) 98112 8032. Os dados coletados nesta entrevista serão analisados e utilizados somente pelo pesquisador, e sua identidade será mantida em sigilo. A sua participação é voluntária e pode ser interrompida a qualquer momento, se esta for a sua vontade.

Se você estiver de acordo em prosseguir, por favor, date e assine abaixo:

Local, ' Ass: 


\section{4.}

Imagens apresentadas durante as entrevistas

As imagens foram apresentadas em arquivo Powerpoint, cada uma correspondendo a um slide:

Slide 1 - Logo e campanhas no site Airbnb
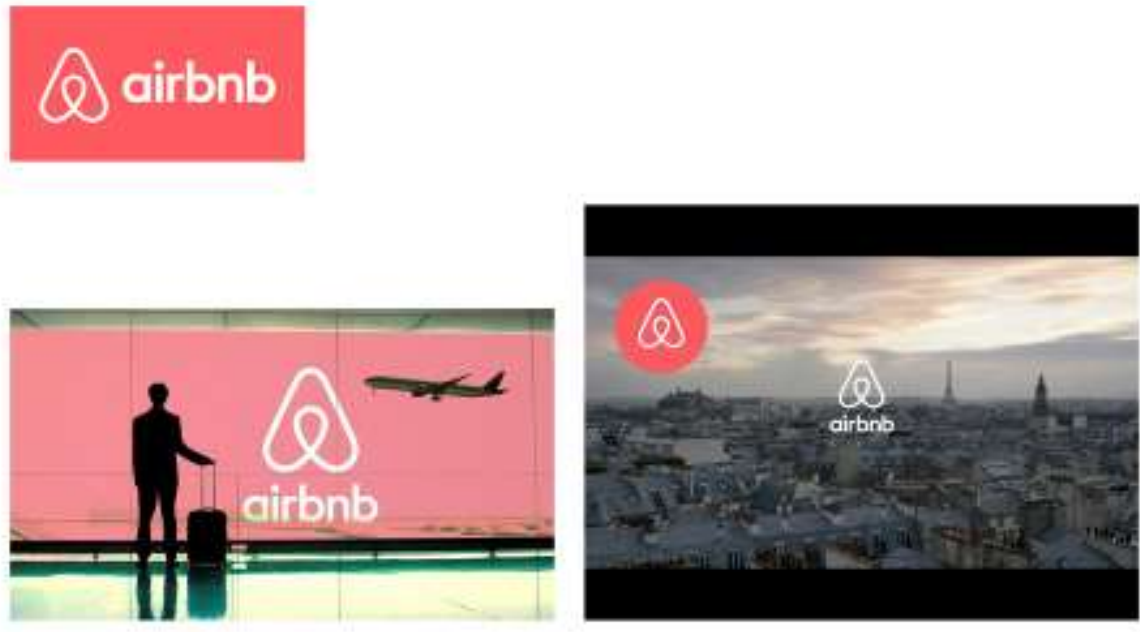

\section{Slide 2 - Tela do site Airbnb}

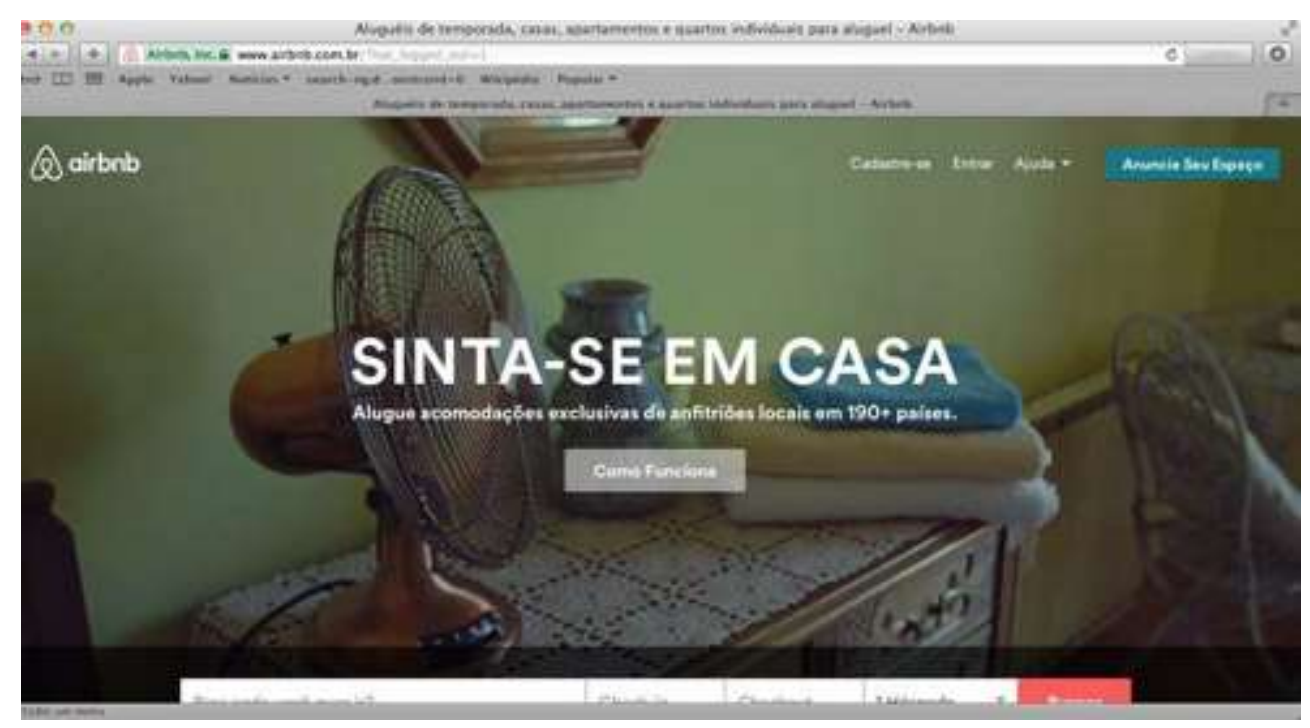


Slide 3 - Peças publicitárias Airbnb
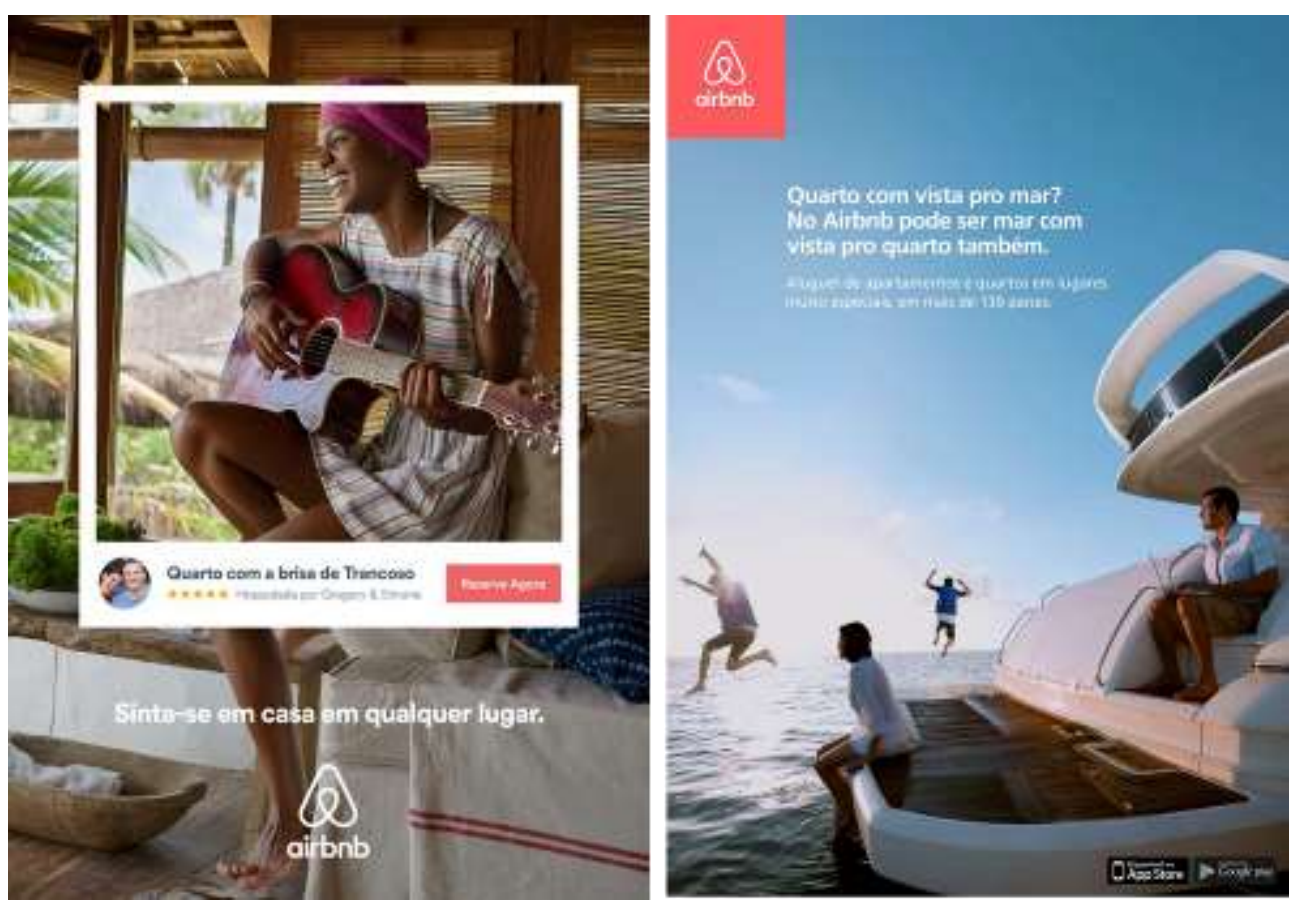

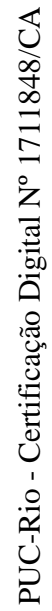

Slide 4 - logo Uber

\section{Uber}


Slide 5 - Peças Publicitárias 1 e 2 - Uber

Peça 1

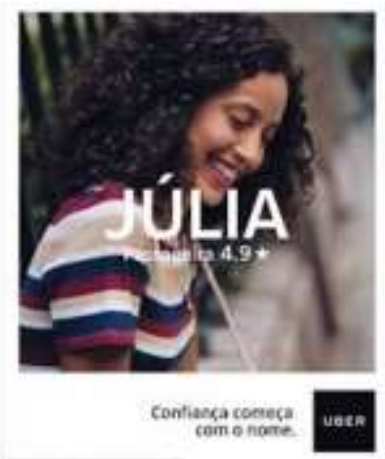

Peça 2

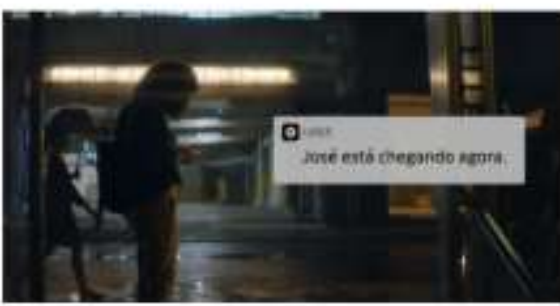

Slide 6 - Peça Publicitária 3 - Uber

Peça 3

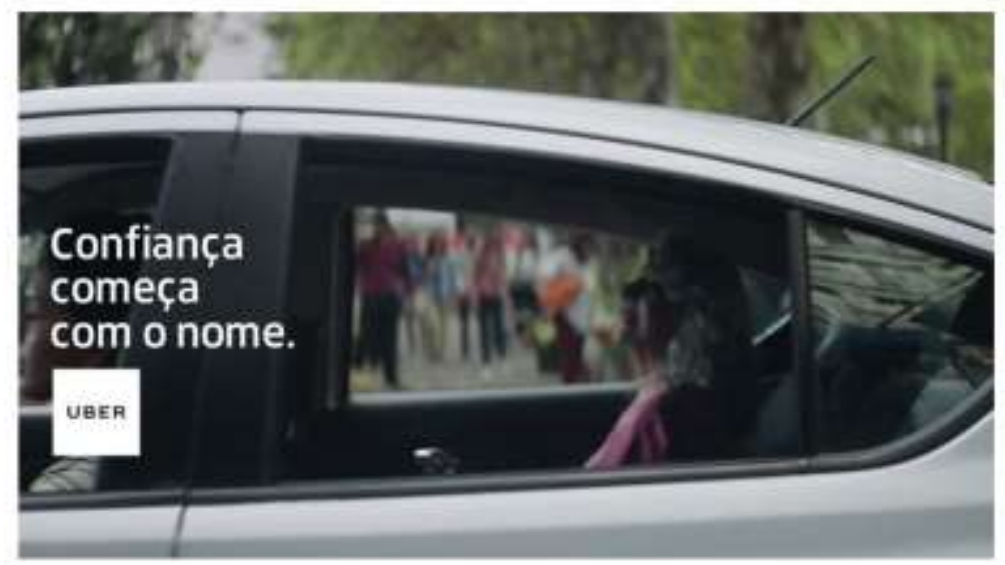

Slide 7 - Peça Publicitária 4 - Uber

Peça 4

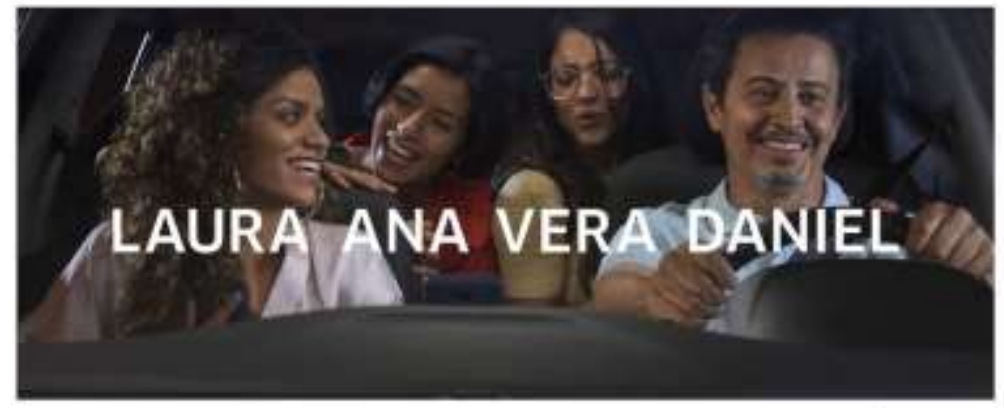

Confiança começa

com o nome. 